\title{
common
}

WEEDS

OF THE

GARADIAR PRAIRIES

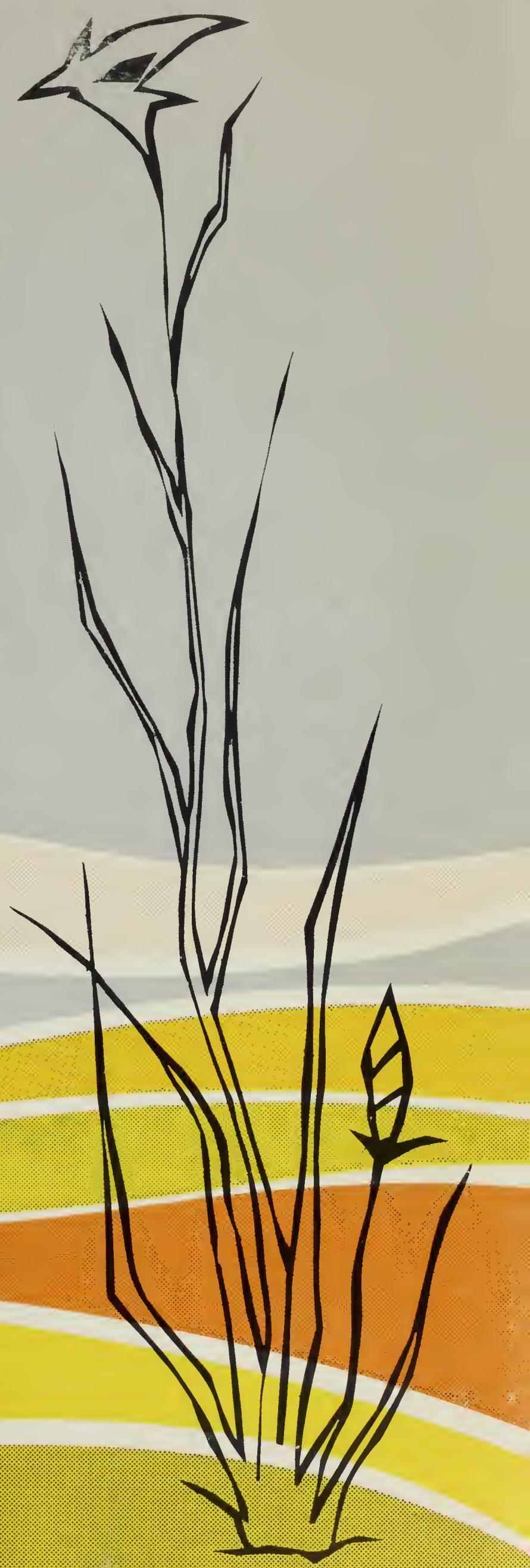



Digitized by the Internet Archive in 2011 with funding from

Agriculture and Agri-Food Canada - Agriculture et Agroalimentaire Canada 



\section{COMMON WEEDS OF THE CANADIAN PRAIRIES}

Aids to Identification by Vegetative Characters

K. F. BEST and A. C. BUDD

Experimental Farm

Swift Current, Saskatchewan

RESEARCH BRANCH

CANADA DEPARTMENT OF

AGRICULTURE

OTTAWA 
Published by

Roger Duhamel, F.R.S.C.

Queen's Printer and Controller of Stationery

Ottawa, Canada

1963

(C) Crown copyrights reserved

Available by mail from the Queen's Printer, Ottawa, and at the following Canadian Government bookshops:

OTTAWA

Daly Building, Corner Mackenzie and Rideau Streets

TORONTO

Mackenzie Building, 36 Adelaide St. East

MONTREAL

Eterna-Vie Building, 1182 St. Catherine St. West

or through your bookseller

Price $\$ 1.00$ Catalogue No. A53-1136-1 (Paper Bound)

Price $\$ 2.00$ Catalogue No. A53-1136-2 (Cloth Bound)

Price subject to change without notice

A deposit copy of this publication is also available for reference in public libraries across Canada 


\section{CONTENTS}

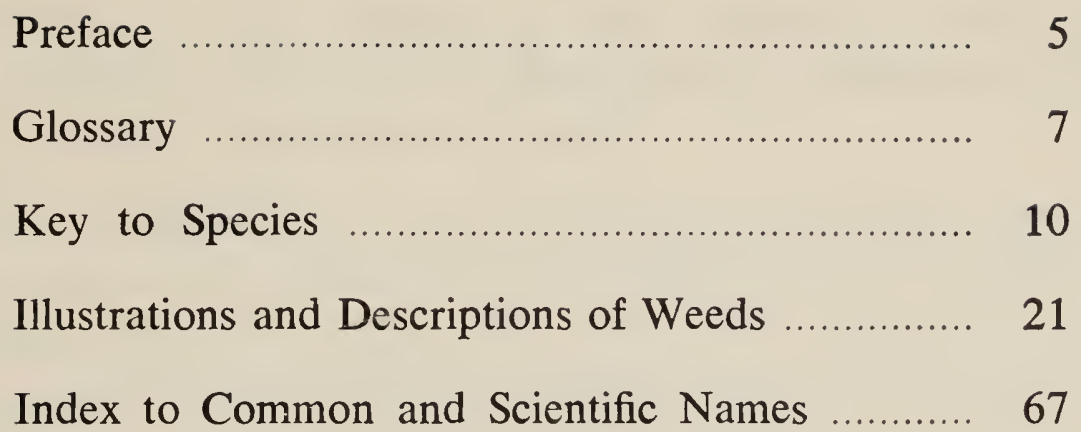





\section{P R E F A C E}

Successful weed control depends on early treatment. It is, then, important to be able to identify a weed when it is still small or immature. This book was written with such early identification in mind.

The key is composed of a series of opposing statements, much like a trueor-false examination. To identify an unknown plant, turn to the first of the statements and follow the trail of clauses that satisfy the specimen in hand. Go from number to number until the trail ends with the name of the plant. The plant may then be checked with the actual description in the text, pages 21 to 65 .

Some 180 species of native and introduced plants are described. The scientific names are based largely on Gray's Manual of Botany, 8th edition, and the common names are the same as those in Wild Plants of the Canadian Prairies, by Archibald C. Budd and Keith F. Best. 



\section{GLOSSARY}

achene: a one-sided, one-celled, dry, hard fruit.

acute: sharp-pointed.

alternate: placed singly at different positions on a stem.

annual: a plant that matures and ripens seed in one year.

anther: the pollen-bearing part of the stamen.

axil: the angle formed where a leaf or branch joins a stem.

beak: a prolonged tip or point.

biennial: a plant that matures and ripens seed in two years.

bract: a small leaf or scale borne below a flower or flower cluster.

calyx: the sepals or outer floral ring.

capsule: a dry fruit composed of more than one chamber.

clasping: having bases partly or entirely surrounding the stem.

compound: divided into separate leaflets.

cordate: heart-shaped, with the point away from the base.

corolla: the petals or inner floral ring.

corymb: a cluster of flowers in which the outer ones open first.

cyme: a cluster of flowers in which the central ones open first.

dentate: with outward-pointing teeth.

discoid: having only ray florets.

disk: the central portion of the head of a composite flower.

downy: with fine soft hairs.

elliptic: equally rounded at both ends.

floret: a small flower, usually present in clusters or heads.

follicle: a fruit with only one chamber.

gland: a secreting organ or structure.

globose: spherical.

hastate: arrow-shaped, with basal lobes pointing outward at wide angles.

head: a short compact cluster of flowers, each more or less stalkless.

hip: the fruit of a rose.

inflorescence: flower cluster; mode of flower bearing.

internode: portion of a stem between two nodes.

involucre: the whorl of bracts below a flower cluster.

lanceolate: longer than wide, broadest toward the base.

leaflet: a single division of a compound leaf.

linear: long and narrow, with parallel margins.

lyrate: pinnatifid, but with an enlarged terminal lobe and smaller lateral lobes.

node: a joint or place on a stem where leaves are attached.

nutlet: a small, dry, one-seeded fruit. 
oblanceolate: longer than wide, broadest near the tip.

oblong: longer than broad, with sides parallel for most of the length.

obovate: egg-shaped, broadest near the tip.

obtuse: blunt or rounded at the end.

ocrea: a sheath formed by fused stipules.

opposite: borne two at a node.

oval: broadly elliptical.

ovary: part of the female organ of a flower containing the seeds.

ovate: egg-shaped, broadest at base.

palmate: having leaflets radiating from one point.

panicle: a flower cluster composed of several combined racemes.

perennial: lasting more than two years.

perfoliate: having a base united around a stem.

petal: the separate section or leaf of a corolla or inner floral ring.

pinnate: a compound leaf with leaflets arranged on a common stalk.

pinnatifid: pinnately cleft or parted.

pod: a dry fruit.

pyxis: a capsule with a lid.

raceme: a cluster of flowers with each flower borne on a short stalk from a common stem. radiate: spreading from or arranged around a common center; bearing ray flowers.

ray: strap-like marginal flower of the composite family.

reflexed: sharply bent or turned downwards.

rosette: a circular cluster of leaves.

rotate: wheel-shaped, flat and circular in outline.

scorpioid: coiled, uncoiling as flowers develop.

sepal: the separate section of a calyx or outer floral ring.

sessile: without a stalk.

spatulate: gradually narrowing downward from a rounded summit.

spike: a flower cluster in which individual flowers are stalkless and borne on a common stem. spur: a hollow extension of some part of a flower.

stamen: the male organ of a flower.

standard: a large upper petal, as in the legume flower.

stipule: an appendage at the base of a leaf.

style: the central portion of the female organ of a flower, between the ovary and the stigma.

trifoliolate: having three leaflets.

tubercle: a rounded, protruding body.

umbel: a flower cluster in which all flower stalks arise from a common point.

valve: separate parts of a capsule or a pod.

whorl: a group of three or more leaves arising from the same node on a stem.

wing: the smaller lateral petals, as in a legume flower. 
Leaf Shapes, Arrangements and Attachments, and Types of Inflorescences

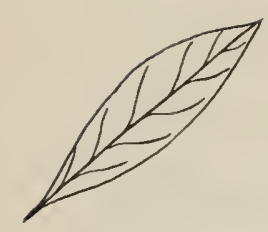

Simple

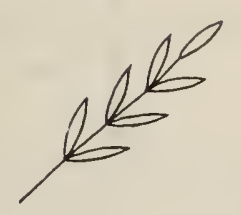

Pinnate

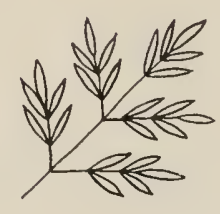

Double pinnate

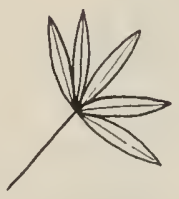

Palmote

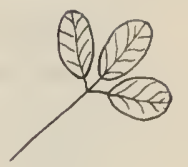

Trifoliolate
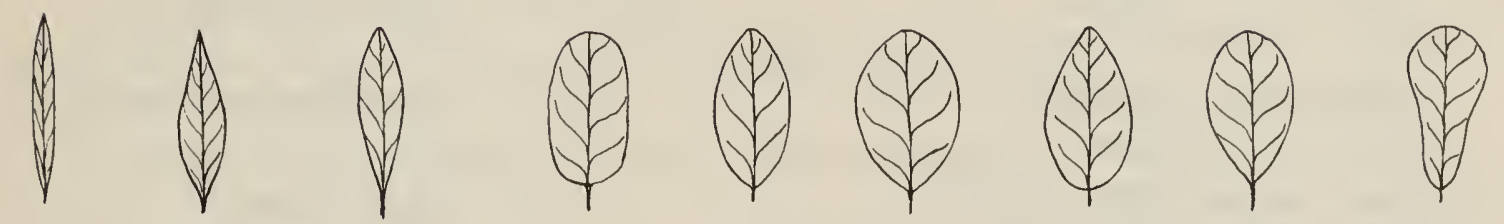

Linear Lonceolate Oblancealate

Oblong

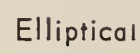

\section{Oval}

Ovate

Obovate Spatulate
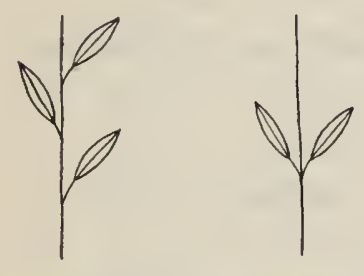

Alternate

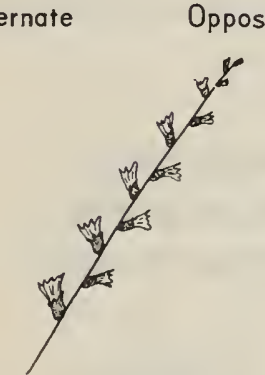

Spike

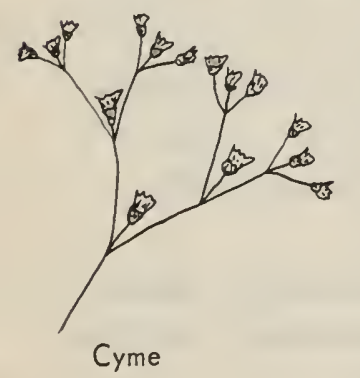

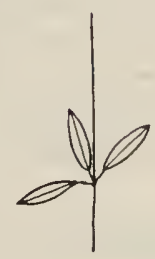

Whorled

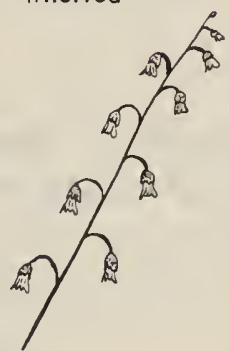

Raceme

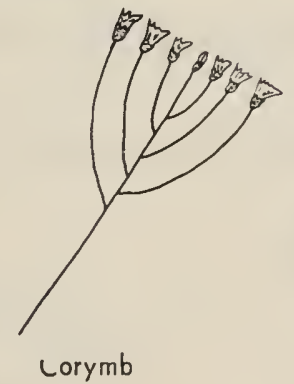

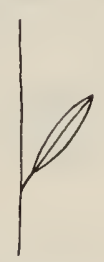

Stalked

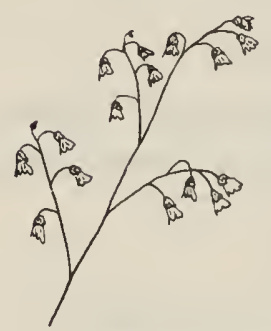

Panicle

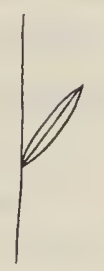

Sessile

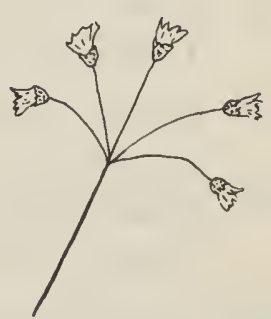

Umbel

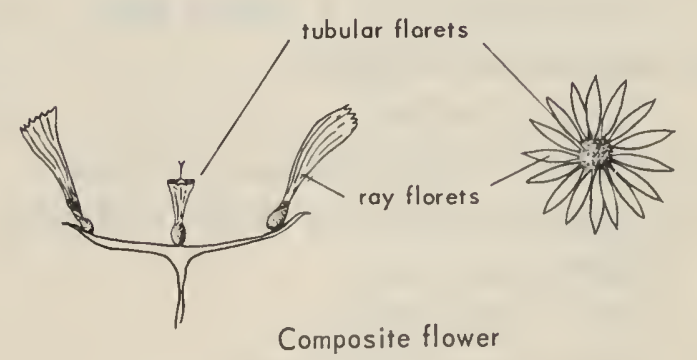




\section{KEY TO SPECIES}

1 Leaves compound ....................................... 2

Leaves simple …........................................ 19

2 Leaves pinnate ......................................... 3

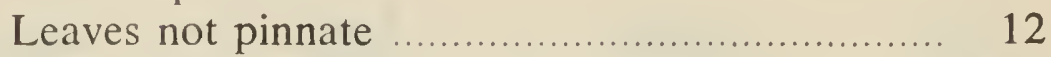

3 Leaves all basal ......................................... 4

Leaves not all basal ...................................... 5

4 Plants with runners ...................................... Potentilla anserina

Plants without runners ..................................... Oxytropis macounii

5 Leaves double-pinnate …................................. Cicuta douglasii

Leaves single-pinnate …............................... 6

6 Plant with thorns .......................................... Rosa woodsii

Plant without thorns _................................... 7

7 Plant almost prostrate …............................... Erodium cicutarium

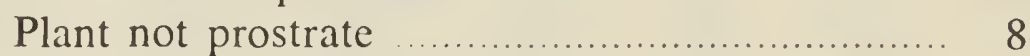

8 Plants with hollow stems ................................ Sium suave

Plants with solid stems ................................. 9

9 Woody-stemmed shrubs …….............................. Potentilla fruticosa

Not woody-stemmed shrubs …........................ 10

10 Leaflets long-linear ..................................... Astragalus pectinatus

Leaflets not long-linear .............................. 11

11 Leaflets usually 5 to 8 pairs; glandular; not scented

Glycyrrhiza lepidota

Leaflets usually 9 to 13 pairs; not glandular; unpleasantly scented

12 Leaves palmate

Leaves trifoliolate ............................................. 14

13 Leaflets toothed, flowers yellow and single ….... Potentilla recta

Leaflets not toothed, flowers blue in racemes ...... Lupinus argenteus

14 Plants hairy

Plants not hairy ............................................. 15

15 Leaflets over 2 inches long ............................ Rhus radicans

Leaflets less than 2 inches long ....................... 16

16 Leaflets not toothed ….................................... Cleome serrulata

Leaflets toothed ............................................. 17

17 Leaflets toothed almost to base ........................ Melilotus alba

Leaflets toothed in upper half only .................. 18

18 Plants erect …............................................ Medicago sativa

Plants prostrate ............................................. Medicago lupulina

19 Leaves nearly all basal .................................. 20

Leaves not all basal ...................................... 24

20 Leaves stalked ........................................... 21

Leaves sessile ............................................ 23 
21 Leaves not lobed

Leaves lobed

22 Leaves hairy

Leaves not hairy

23 Plants with milky sap, leaves over $1 \frac{1}{2}$ inches long Plants without milky sap, leaves less than $1 \frac{1}{2}$ inches long

24 Leaves alternate on stem

Leaves opposite on stem

25 Leaves stalked

Leaves not stalked

26 Most of leaves cleft halfway or more to midrib

Most of leaves not cleft halfway to midrib

27 Leaves palmately divided

Leaves not palmately divided

28 Leaves grayish, with fine starry hairs

Leaves green, hairs not starry

29 Leaves divided almost to base, final segments sharp, flowers yellow

Leaves divided right to base, final segments blunt, flowers blue

30 Leaves spiny

Leaves not spiny

31 Upper leaves clasping stem

Upper leaves not clasping; stem winged

32 Plants with milky sap, leaves with soft prickles

Plants without milky sap, leaves with stiff prickles

33 Leaves merely deeply cleft or 1-pinnate

Leaves 2 to 3 times pinnatifid

34 Plants hairy

Plants not hairy

35 Upper leaves stalked

Upper leaves not stalked

36 Plants low, branched from base

Plants erect, branched above

37 Stem hairs spreading

Stem hairs reflexed

38 Annual with downward pointing hairs, leaf lobes obtuse

Perennial with running rootstocks, leaf lobes acute

39 Upper leaves clasping

Upper leaves not clasping

40 Leaf segments toothed

Leaf segments entire

41 Creeping-rooted perennial

Fibrous-rooted annual
Plantago major

22

Hypochaeris radicata

Taraxacum officinale

Hieracium aurantiacum

Androsace septentrionalis

25

var. puberulenta

195

26

107

27

53

28

30

Malvastrum coccineum

29

Ranunculus acris

Delphinium bicolor

31

33

32

Carduus nutans

Sonchus oleraceus

Cirsium arvense

34

43

35

39

36

38

Solanum triflorum

37

Sisymbrium altissimum

Sisymbrium loeselii

Erucastrum gallicum

Ambrosia psilostachya

var. coronopifolia

Senecio vulgaris

40

41

42

Rorippa sylvestris

Rorippa islandica 
42 Plants low, spreading

Plants erect

43 Leaf segments toothed

Leaf segments entire

44 Leaf stalks slightly winged, many stemmed

Leaf stalks not winged, single stemmed

45 Plants hairy

Plants not hairy (except Achillea lanulosa)

46 Leaf segments narrow linear

Leaf scgments not narrow linear

47 Woody-based perennial, silvery gray

Annual, plants green

48 Plants branched

Plants not branched

49 Leaf segments threadlike or linear

Leaf segments not threadlike or linear

50 Plants with pineapple odor

Plants without pineapple odor

51 Leaf segments linear

Leaf segments threadlike

52 Flowers yellow, plant almost hairless

Flowers white, plant hairy

53 Leaves entire or with basal lobes

Leaves toothed or divided

54 Leaves with basal lobes

Leaves without basal lobes

55 Plants with ocrea

Plants without ocrea

56 Plants with weak twining stems

Plants without weak twining stems

57 Perennial with running roots, leaves mostly basal

Annual, plant leafy throughout

58 Plants creeping or twining

Plants not creeping or twining

59 Upper leaves heart-shaped at base

Upper leaves not heart-shaped at base

60 Calyx enclosed in two large bracts, leaves pointed

Calyx not enclosed in two large bracts, leaves blunt

61 Tall-growing biennial

Prostrate annual

62 Plants with ocrea

Plants without ocrea

63 Leaves with wavy margins, over 2 inches long

Leaves without wavy margins, less than 2 inches long
Solanum triflorum

Reseda lutea

44

45

Tanacetum vulgare

Artemisia biennis

46

48

47

Artemisia absinthium

Artemisia frigida

Descurainia sophia

49

52

50

Ambrosia artemisiifolia var. elatior

51

Matricaria maritima var. agrestis

Matricaria matricarioides

Matricaria chamomil'a

Senecio jacobaea

Achillea lanulosa

54

88

55

62

56

58

Polygonum convolvulus

57

Rumex acetosella

Fagopyrum tataricum

59

61

Solanum dulcamara 60

Convolvulus sepium

var. americanu.s

Convolvulus arvense

Arctium minus

Monolepis nuttalliana

63

65

Rumex crispus

64 
64 Plants prostrate

Plants erect

65 Upper leaves clasping

Upper leaves not clasping

66 Basal leaves divided

Basal leaves not divided

67 Stems hollow, fleshy, hairless when mature, cobwebby when young

Stems not hollow, soft-hairy

68 Basal leaves divided

Basal leaves not divided

69 Much-branched annual

Little-branched biennial

70 Stem whitish

Stem not whitish

71 Leaves spine-tipped

Leaves not spine-tipped

72 Leaves linear to linear-lanceolate

Leaves not linear to linear-lanceolate

73 Stems purple

Stems not purple

74 Plants hairy

Plants not hairy

75 Perennials with milky sap

Annuals without milky sap

76 Leaf with vein parallel to margin

Leaf without vein parallel to margin

77 Plants rough hairy

Plants not rough hairy

78 Hairs stiff and glass-like

Hairs soft, not glass-like

79 Plants with running roots

Plants without running roots

80 Annual, leaves green

Perennial, leaves grayish

81 Plants prostrate

Plants not prostrate

82 Stems reddish at base

Stems not reddish at base

83 Leaves fleshy and spatulate

Leaves not fleshy

84 Stems with stiff hairs

Stems without stiff hairs

85 Lower leaves spatulate, toothed

Lower leaves ovate, entire

86 Plants climbing

Plants not climbing

87 Leaves ovate, fruit a berry

Leaves cordate, fruit a bur
Polygonum aviculare

Rumex venosus

66

68

Lepidium perfoliatum

67

Senecio palustris

Cynoglossum officinale

69

70

Centaurea diffusa

Centanea maculosa

71

72

Amaranthus albus

Oenothera nuttallii

73

81

Brachyactis angusta

74

76

75

Euphorbia esula

Axyris amaranthoides

Epilobium angustifolium

77

78

79

Lappula echinata

Erigeron canadensis

Linaria vulgaris

80

Erysimum cheiranthoides

Erysimum inconspicuum

Amaranthus graecizans

82

Amaranthus retroflexus

83

Heliotropium curassa-

vicum var. obovatum

84

85

86

Erigeron canadensis

Helianthus petiolaris

Solanum dulcamara

87

Solanum nigrum

Arctium minus 
88 Plants with milky sap

Plants without milky sap

89 Plants hairy

Plants not hairy

90 Basal leaves deeply lobed

Basal leaves not deeply lobed

91 Pods jointed, upper leaves lyrate

Pods not jointed, upper leaves not pinnately lobed

92 Plants almost prostrate, leaves circular

Plants almost erect, leaves lanceolate

93 Plants prostrate

Plants erect

94 Upper leaves clasping stem

Upper leaves not clasping stem

95 Leaves cleft or divided

Leaves not cleft or divided

96 Flowers white, pods fan-shaped, flattened, winged

Flowers yellow, pods globular

97 Leaves linear to oblanceolate

Leaves not linear to oblanceolate

98 Leaves with vein parallel to margin

Leaves without vein parallel to margin

99 Plants sticky, flowers pink, stems 4-angled

Plants not sticky, flowers yellow

100 Plants scurfy or mealy

Plants not scurfy or mealy

101 Stems smooth

Stems with verticle grooves

101 Leaves green above, white below; margins wavy

Leaves green on both surfaces, margins smooth

103 Stems swollen at joints

Stems not swollen at joints

104 Leaves with large terminal lobes

Leaves without large terminal lobes

105 Leaves sharply lobed, stem grooved

Leaves with wavy margins

106 Flowers yellow, plants with stipules

Flowers white, plants without stipules

107 Some leaves cleft or divided

No leaves cleft or divided

108 Leaves clasping

Leaves not clasping

109 Leaves prickly-margined

Leaves not prickly-margined

110 Row of prickles on underside of midvein

No row of prickles on underside of midvein
Euphorbia helioscopia

89

90

93

91

92

Raphanus raphanistrum

Sinapis arvensis

Malva rotundifolia

Oenothera biennis

Chenopodium salinum

94

95

97

Rorippa sinuala

96

Thlaspi arvense

Rorippa austriaca

98

100

Epilobium angustifolium

99

Epilobium glandulosum var. adenocaulon

Diplotaxis muralis

101

103

Atriplex hortensis

102

Chenopodium album

Atriplex patula

Mirabilis nyctaginea

104

Brassica juncea

105

Chenopodium rubrum

106

Viola arvensis

Solanum nigrum

108

142

109

121

110

114

Lactuca scariola

111 
111 Flowers purple or white, without milky sap, leaf spines stiff

Flowers yellow, milky sap, leaf spines soft

112 Perennials from creeping rootstocks

Annuals with taproots

113 Ears at base of clasping leaves rounded

Ears at base of clasping leaves acutely pointed

114 Plants with milky sap

Plants without milky sap

115 Slender annual, not hairy, flowers yellow

Branched perennial, hairy, flowers blue

116 Plants hairy

Plants not hairy

Cirsium arvense

112

Sonchus arvensis

113

Sonchus asper

Sonchus oleraceus

115

116

Crepis tectorum

Cichorium intybus

117

118

117 Sticky biennial, evil smelling, flowers greenishyellow

Annual, flowers small, white

Hyoscyamus niger

Capsella bursa-pastoris

Chrysanthemum leucan-

themum

Much-branched annual

119

Senecio vulgaris

120

Stems not hollow

120 Seed pods oval, upper leaves perfoliate, lower leaves much divided

Seed pods linear, upper leaves clasping, all leaves entire

\section{Lepidium perfoliatum}

Conringia orientalis

122

127

122 Leaves silvery-gray, plant low and much branched, flowers yellow

Haplopappus spinulosus

Leaves green, plant tall and not much branched, flowers not yellow

123

Carduus nutans

124

125

126

Cirsium undulatum

Cirsium vulgare

Cirsium flodmanii

Cirsium arvense

128

135

129

131

130

Sinapis arvensis

Centaurea repens

Centaurea solstitialis

Achillea lanulosa

132

Artemisia frigida

133 
133 Plants with a distinct odor Plants without odor

134 Leaves thin and stalked

Leaves thick and stalkless

135 Leaf segments thread-like

Leaf segments not thread-like

136 Flowers discoid, greenish-yellow

Flowers radiate, white

137 Plants odorless

Plants with odor

138 Leaves much divided

Leaves merely lobed

139 Flowers insignificant, in leafy spike

Flowers showy, yellow, in terminal clusters

140 Plants with milky sap

Plants without milky sap

141 Plants branched from base

Plants not branched from base

142 Leaves toothed

Leaves entire

143 Upper leaves clasping

Upper leaves not clasping

144 Coarse hollow-stemmed annual

Plant not hollow stemmed

145 Plants hairy

Plants not hairy

146 Pods inflated

Pods flattened

147 Creeping-rooted perennial with rough leaves

Annual with smooth leaves

148 Plants hairy

Plants not hairy

149 Plants prostrate

Plants erect

150 Plants with pods

Plants with capsules

151 Pods short

Pods long

152 Perennial, leaves grayish

Annual, leaves green

153 Annual, upper leaves linear

Biennial, leaves lanceolate to ovate-lanceolate

154 Plants with milky sap

Plants without milky sap

155 Plants sticky

Plants not sticky

156 Flower heads sticky

Whole plant sticky
Artemisia absinthium

134

Artemisia psilostachya

Ambrosia artemisiifolia

var. elatior

136

138

Matricaria matricarioides

137

Matricaria maritima

var. agrestis

Matricaria chamomilla

139

140

Artemisia biennis

Senecio jacobaea

Lactuca pulchella

141

Lepidium ramosissimum

Lepidium densiflorum

143

159

144

148

Senecio palustris

145

146

147

Cardaria pubescens

var. elongata

Cardaria draba

Rorippa austriaca

Thlaspi arvense

149

154

Veronica persica

150

151

153

Camelina microcarpa

152

Erysimum asperum

Erysimum cheiranthoides

Erigeron canadensis

Oenothera biennis

Euphorbia heliscopia

155

156

157

Grindellia perennis

Epilobium glandulosum var. adenocaulon 
157 Lateral vein on leaf margin

No lateral vein

158 Leaves lanceolate and decurrent, plant tall

Leaves spatulate to linear, not decurrent, plant short

159 Upper leaves clasping

Upper leaves not clasping

160 Leaves grass-like

Leaves not grass-like

161 Plants hairy

Plants not hairy

162 Fruit pods

Fruit not pods

163 Pods round

Pods long ascending

164 Flowers spurred

Flowers not spurred

165 Leaves linear to lanceolate

Leaves not linear to lanceolate

166 Plants with thick fleshy stems, leaves almost absent

Plants without thick fleshy stems

167 Stems globose and on ground

Stems erect and flattened

168 Leaves few and scale-like

Leaves not scale-like

169 Plants with white shreddy bark

Plants without white shreddy bark

170 Low spiny shrub

Shreddy-barked herb

171 Plant hairy

Plants not hairy

172 Plants bushy, branching from base

Plants erect, not bushy

173 Stems purple

Stems not purple

174 Leaves three-nerved

Leaves not three-nerved

175 Whole plant with long silky hairs

Not long silky haired

176 Flowers solitary in leaf axils

Flowers in narrow spikes

177 Plants sticky and scented

Plants not sticky and scented

178 Fruit in pods

Fruit not in pods
Epilobium angustifolium

158

Helenium autumnale var. montanum

Veronica peregrina var. xalapensis

160

165

Tragopogon dubius

161

162

164

163

Cynoglossum officinale

Neslia paniculata

Arabis glabra

Linaria dalmatica

Rorippa austriaca

166

189

167

168

Mamillaria vivipara

Opuntia polyacantha

Lygodesmia juncea

169

170

171

Sarcobatus vermiculatus

Oenothera nuttallii

172

183

173

177

Brachyactis angusta

174

Kochia scoparia

175

Cryptantha fendleri

176

Corispermum hyssopifolium

Bassia hyssopifolia

Madia glomerata

178

179

181 
179 Flowers yellow, perennial

Flowers white, annual

180 Leaves lanceolate, pods oval

Leaves linear-oblong to spatulate, pods circular

181 Hairs stiff and glass-like, flowers blue

Hairs not glass-like, flowers white

182 Stem hairs appressed

Stem hairs spreading

183 Plants branching from base

Plants not branching from base

184 Leaves with spiny tips

Leaves without spiny tips

185 Running-rooted, leaves obovate to linearoblong

Taprooted, leaves narrowly linear

186 Plants with milky sap

Plants without milky sap

187 Leaves rough, mostly opposite

Leaves not rough

188 Flowers spurred, yellow, plant 12 to 24 inches high

Flowers not spurred, white, plant 6 to 12 inches high

189 Plants erect

Plants prostrate

190 Plants hairy

Plants not hairy

191 Leaves mostly basal

Plants leafy throughout

192 Fruit pods

Fruit not pods

193 Plants woolly, leaves broad and flannelly

Plants bristly-haired, leaves narrow

194 Nerves distinct, leaves spatulate to linear, $\frac{1}{2}$ to 1 inch long

Nerves not distinct, leaves fleshy, spatulate, $\frac{3}{4}$ to 2 inches long

195 Leaves stalked

Leaves sessile

196 Leaves cleft or divided

Leaves not cleft or divided

197 Plants less than 12 inches high

Plants over 12 inches high

198 Leaves grayish

Leaves green
Erysimum inconspicuum

180

Berteroa incana

Alyssum alyssoides

Erigeron canadensis

182

Lappula echinata

Lappula redowskii var. occidentalis

184

186

Salsola pestifer

185

Iva axillaris

Gutierrezia diversifolia

Euphorbia esula

187

Helianthus subtuberosus 188

\section{Linaria vulgaris}

Veronica peregrina var. xalapensis

190

Portulaca oleracea

191

194

192

193

Draba nemorosa

Hieracium aurantiacum

Verbascum thapsus

Erigeron canadensis

Veronica peregrina var. xalapensis

Heliotropium curassavicum var. obovatum

196

221

197

202

198

199

Picradeniopsis oppositifolia

Erodium cicutarium 
199 Leaf divisions linear

Leaf divisions not linear

200 Some leaves entire, some 3- to 5-lobed

No leaves entire

201 Running perennial roots

Annual, taproot

202 Leaves toothed

Leaves not toothed

203 Stems square

Stems not square

204 Plants prostrate

Plants erect

205 Upper leaves sessile

Upper leaves stalked

206 Stems decidedly hairy

Stems only slightly hairy

207 Perennial with pink roots

Annual or biennial with taproot

208 Plants erect

Plants prostrate

209 Annual

Sticky perennial

210 Leaves oblong-linear

Leaves ovate

211 Leaves long-stalked, stem downy

Leaves short-stalked, stem hairy

212 Stems swollen at nodes

Stems not swollen at nodes

213 Leaves with red center line, plants prostrate ...

Leaves without red center line, plants semiprostrate, creeping

214 Shrub

Not a shrub

215 Plants prostrate

Plants erect

216 Leaves oblong, plants with milky sap

Leaves ovate, plants without milky sap, with fine line of hair down stem

217 Plants with milky sap

Plants without milky sap

218 Leaves flannelly

Leaves not flannelly

219 Stem leaves drooping or spreading

Stem leaves ascending
Coreopsis tinctoria

200

Ambrosia trifida

201

Ambrosia psilostachya var. coronopifolia

Ambrosia artemisiifolia var. elatior

203

214

204

208

Glecoma hederacea

205

Salvia sylvestris

206

207

Moldavica parviflora

Urtica gracilis

Galeopsis tetrahit

209

213

Epilobium glandulosum

210

var. adenocaulon

Veronica peregrina

var. xalapensis

211

Iva xanthifolia

212

Mirabilis hirsutus

Galinsoga ciliata

Euphorbia serpyllifolia

Veronica persica

Symphoricarpos occidentalis

215

216

217

Euphorbia glyptosperma

Stellaria media

218

220

Asclepias speciosa

219

Apocynum androsaemi-

folium

Apocynum sibiricum 
220 Plants rough to touch

Plants not rough to touch

221 Leaves divided

Leaves not divided

222 Annual

Perennial with running roots

223 Upper leaves clasping

Upper leaves not clasping

224 Plants with milky sap

Plants without milky sap

225 Leaves ovate-lanceolate, annual

Leaves elliptic-lanceolate, biennial

226 Leaves linear to lanceolate

Leaves not linear or lanceolate

227 Leaves toothed

Leaves entire

228 Plants sticky

Plants not sticky

229 Plants hairy

Plants not hairy

230 Leaves less than 1 inch long

Leaves more than 1 inch long

231 Leaves linear

Leaves oblanceolate

232 Flowers in racemes

Flowers in cymes

233 Stem jointed

Stem not jointed

234 Leaves whorled

Leaves not whorled

235 Plants annual

Plants perennial

236 Flowers white

Flowers not white

237 Plants annual, 12 to 18 inches high

Plants perennial, 24 to 36 inches high

238 Stems square

Stems not square

239 Plants prostrate

Plants erect

240 Leaf margins toothed

Leaf margins entire

241 Annual with line of white hairs down stem

Perennial with reflexed stem hairs

242 Leaves large and cordate

Leaves not large and cordate
Helianthus petiolaris

Mirabilis nyctaginea

222

223

Ambrosia artemisiifolia var. elatior

Ambrosia psilostachya

var. coronopifolia

224

226

A pocynum sibiricum

225

Saponaria vaccaria

Silene cserei

227

239

228

229

Epilobium glandulosum var. adenocaulon

Rhinanthus crista-galli

230

233

Veronica peregrina

var. xalapensis

231

Agrostemma githago

232

Silene dichotoma

Silene noctiflora

234

236

Spergula arvensis

235

Silene antirrhinum

Silene cucubalus

237

238

Gypsophila elegans

Gypsophila paniculata

Salvia sylvestris

Veronica peregrina

240

var. xalapensis

242

Veronica persica

241

Stellaria media

Cerastium arvense

Mirabilis nyctaginea

Lychnis alba 


\section{ILLUSTRATIONS AND DESGRIPTIONS OF WEED SPECIES}
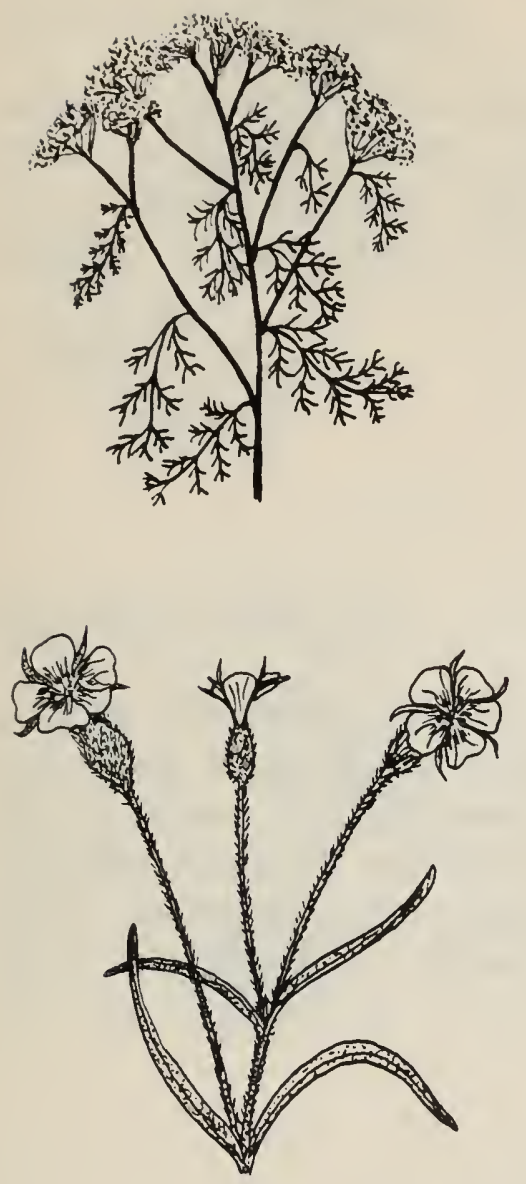

Achillea lanulosa Nutt.

WOOLLY YARROW

A perennial with shallow rootstocks, 2 feet high, usually covered with silky hairs. Leaves 1 to 6 inches long, finely divided. Flowers in compact, round-tipped clusters, usually white, about $\frac{1}{4}$ inch across. A common plant on prairie and roadsides.

\section{Agrostemma githago $\mathrm{L}$.}

PURPLE COCKLE

A hairy, erect annual 1 to $2 \frac{1}{2}$ feet high, with a taproot. Leaves linear, hairy, to 4 inches long. Flowers single, purple, at head of stems, with hairy sepals united at base and lobes much longer than petals. Seeds poisonous to chickens. Introduced from Europe. Not very common.

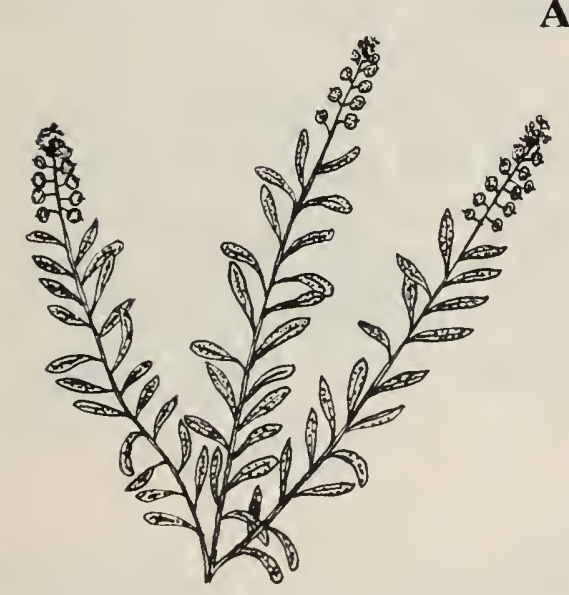

Alyssum alyssoides L.

SMALL ALYSSUM

An annual 4 to 12 inches high, with starry hairs. Leaves linear-oblong to spatulate, $\frac{1}{4}$ to $\frac{1}{2}$ inch long. Flowers in narrow racemes, $\frac{3}{16}$ inch across, creamy-white. Pods almost round, yellowish, with a narrow flat margin. Not very common.

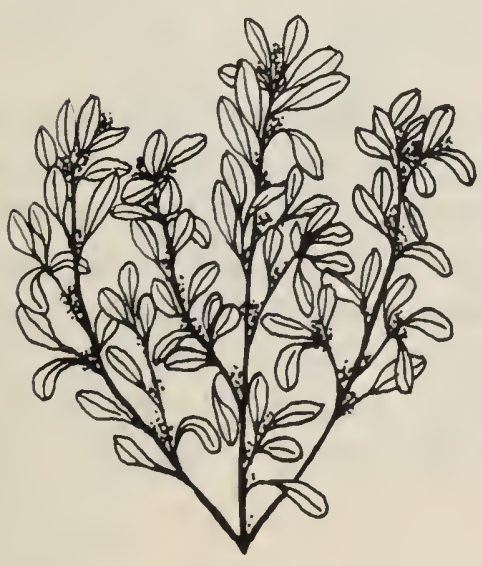

Amaranthus albus L.

TUMBLEWEED

A bushy annual with white, much-branched stems, up to 2 feet high. Leaves dull, spatulate, midvein usually extended into a tiny spine. Flowers in small leaf-axil clusters. A common native weed of waste ground and roadsides. When dry, it breaks off and tumbles with the wind. 
Amaranthus graecizans L. PROSTRATE AMARANTH

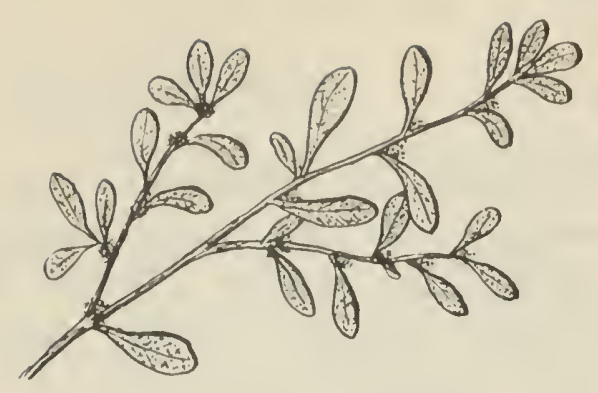

A flat, coarse annual with fleshy, reddish stems forming mats. Leaves shiny-green, $\frac{1}{4}$ to 1 inch long, spatulate. Flowers produced in leaf axils. Although not native, it is a common garden weed.

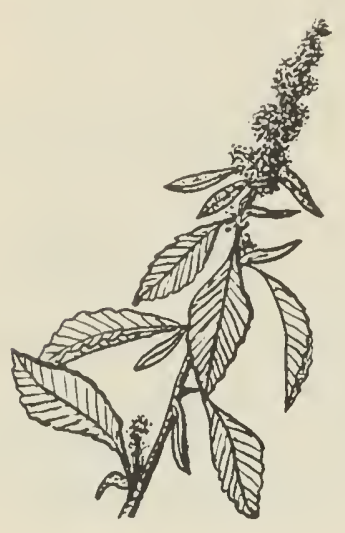

Amaranthus retroflexus L.

RED-ROOT PIGWEED

An erect annual with a reddish root, to $2 \frac{1}{2}$ feet high, with angular, rough stems somewhat hairy at the tips. Leaves stalked, ovate, rough, 3 to 4 inches long. Flowers in dense spikes in leaf axils and in large terminal spike. Very common along roadsides, in fields and waste places.

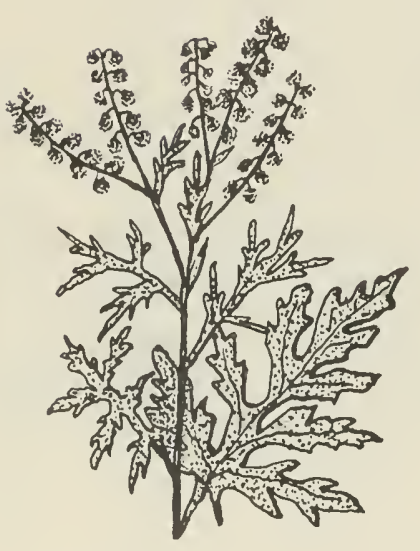

Ambrosia artemisiifolia L.

COMMON var. elatior (L.) Descourtils

RAGWEED

An erect annual to 3 feet high, with stalked leaves, much divided and gray-hairy beneath. Male heads numerous, in long, narrow racemes; female heads in small clusters. A weed of waste places and roadsides, common in the eastern portions but scarcer further west.

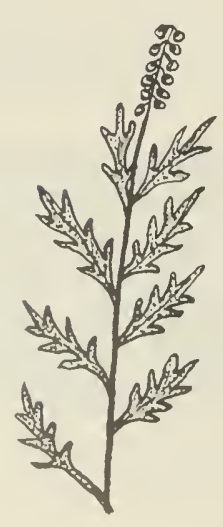

Ambrosia psilostachya DC. var. coronopifolia (T. \& G.) Farwell

PERENNIAL RAGWEED

A grayish, hairy, erect perennial 12 to 36 inches high, with running rootstocks. Leaves opposite above, alternate below, stalkless and once or twice divided. Male heads numerous, in long narrow racemes; female heads in small clusters. Fruit nut-like. Fairly common in eastern portions along roadsides and waste places, but scarcer to the west. 


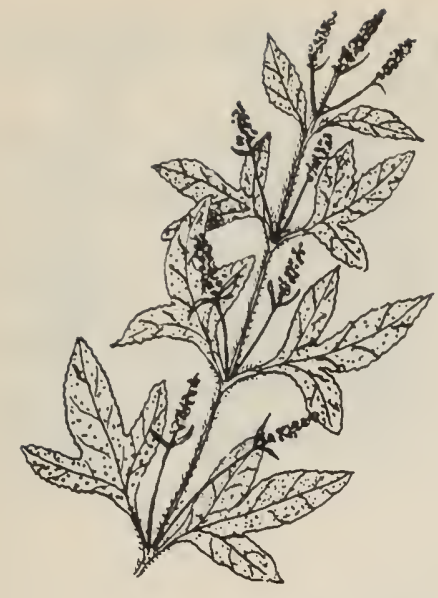

Ambrosia trifida L.

An erect annual 2 to 5 feet high, with a rough, stout, hairy stem. Leaves 2 to 10 inches wide, all opposite, stalked, usually 3- to 5lobed but upper ones entire and with three main veins. Male flowers in long terminal racemes; female ones in clusters in axils of upper leaves. Common in southeastern prairies along roadsides but scarce elsewhere.

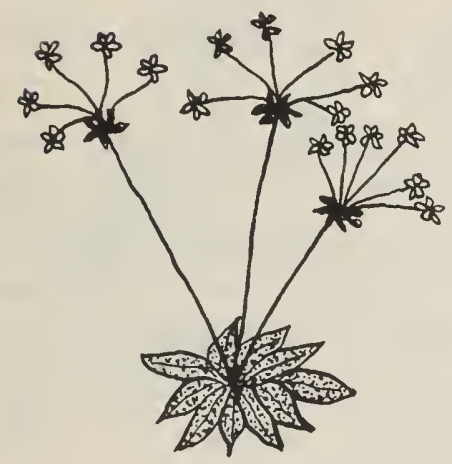

Androsace septentrionalis L.

PYGMYFLOWER

var. puberulenta (Rydb.) Knuth

A low-growing annual with leaves less than $1 \frac{1}{2}$ inches long, mostly basal. Found on eroded and dry soils and often plentiful on stubble fields and cultivated land in early spring. A common plant but so small that it is not generally noticed.

Apocynum androsaemifolium L.

SPREADING DOGBANE

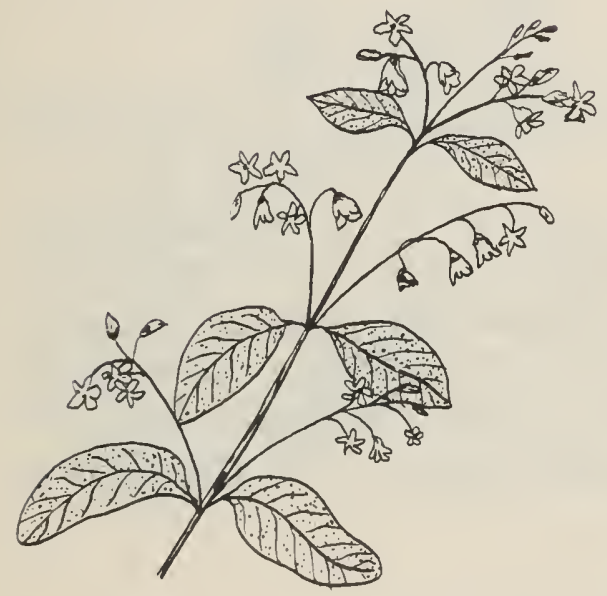

A husky perennial from horizontal rootstocks, to 4 feet high, much-branched, with a milky sap. Leaves opposite, oval or ovate, 1 to 3 inches long, lighter and slightly hairy on underside. Flowers pink, in clusters at ends of branches and in leaf axils. Fruits pods, tubular, in pairs about 4 inches long, containing hairytipped seeds. Common in woodlands and on light sandy soils.

Apocynum sibiricum Jacq.

CLASPING-LEAVED DOGBANE

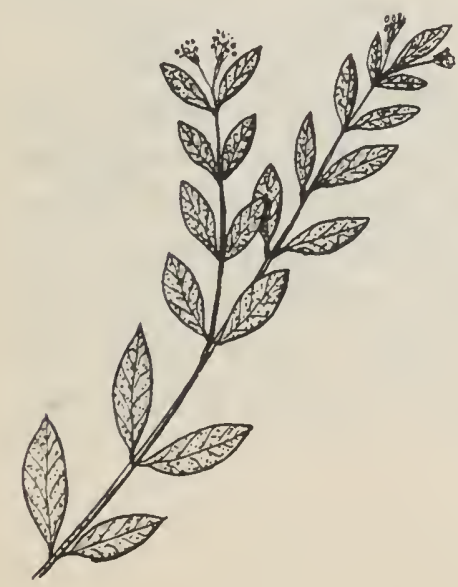

A perennial 1 to 2 feet high, with tough, running rootstocks. Leaves 1 to 3 inches long, oblong to ovate, pale-green, with a blunt or rounded base, either clasping the stem or having very short stalks. Stems with milky sap. Flowers greenish-white, in clusters at ends of stems. Fruits a pair of long pods. Common in moist, sandy soils and creek banks. 

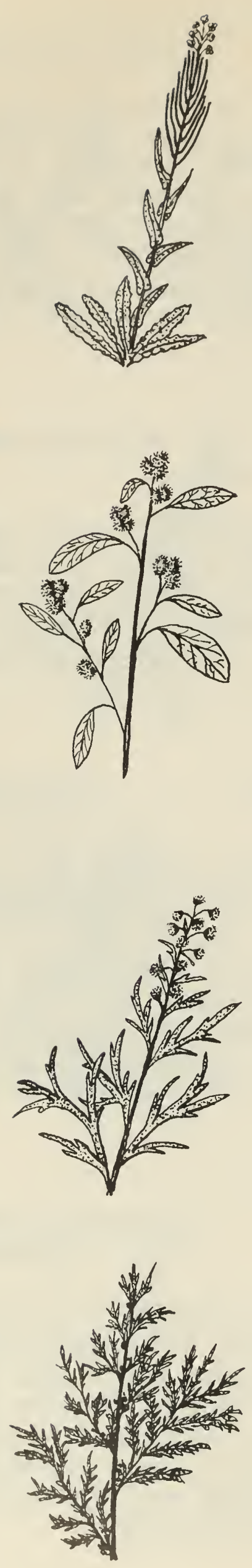

Arabis glabra (L.) Bernh.

TOWER MUSTARD

A biennial 1 to 3 feet high, with a smooth upper stem. Basal leaves slightly hairy, 2 to 6 inches long, with short stalks. Stem leaves arrow-shaped at base, stalkless. Flowers greenish-white or yellowish-white. Pods erect, pressed close to stem, about 2 to 4 inches long. Not very common, although plentiful in Cypress Hills.

Arctium minus (Hill) Bernh.

LESSER BURDOCK

A tall, coarse, branching biennial with deep, thick taproots. Leaves large, heart-shaped, pale and downy beneath, to 12 inches long. Flower heads numerous, in one-sided, leafy racemes. An introduced and widely distributed weed. The burs or seed-bearing heads are very prickly and are easily transported on clothes or on the fur of animals.

\section{Artemisia absinthium L.}

ABSINTHE

A shrubby perennial to 4 feet high, with much-branched, finely hairy stems. Leaves 2 to 5 inches long, divided into oblong or ovate segments, with fine-grayish hairs. Flower heads stalked, drooping, in spike-like panicles. Sometimes found in waste places as an escape from gardens.

Artemisia biennis Willd.

BIENNIAL WORMWOOD

An annual or biennial 1 to 4 feet high, with coarse, somewhat reddish, hairless stems. The early rosette leaves are divided two or three times into toothed segments, stem leaves and upper leaves once or twice divided into narrow segments. Flowers in short, tight spikes in upper leaf axils. Common in moist places over the area. 


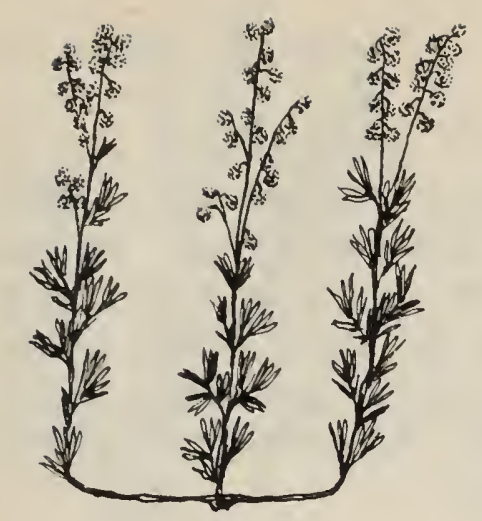

Artemisia frigida Willd.

A perennial from a somewhat woody base, to 20 inches high, silvery-gray, with dense silky hair. Leaves $\frac{1}{2}$ to $1 \frac{1}{2}$ inches long, several times divided into linear segments. Flower heads many, yellow, in terminal racemes. Has a distinct odor when handled. Quite common and very conspicuous in overgrazed pastures.

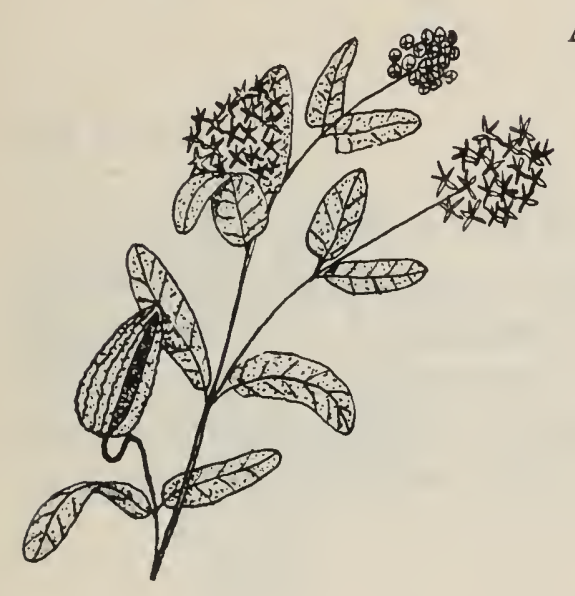

Asclepias speciosa Torr.

SHOWY MILKWEED

An erect, milky-sapped perennial with deep taproots, usually in large colonies, to $2 \frac{1}{2}$ feet high. Leaves broad, oval, rounded or somewhat heart-shaped at base, with whitish down, 3 to 6 inches long. Flowers pinkish-purple to fleshcolored, $\frac{1}{3}$ to $\frac{1}{2}$ inch across, in dense, round umbels 2 to 3 inches in diameter. Fruit a follicle or large pod, containing many tufted seeds.

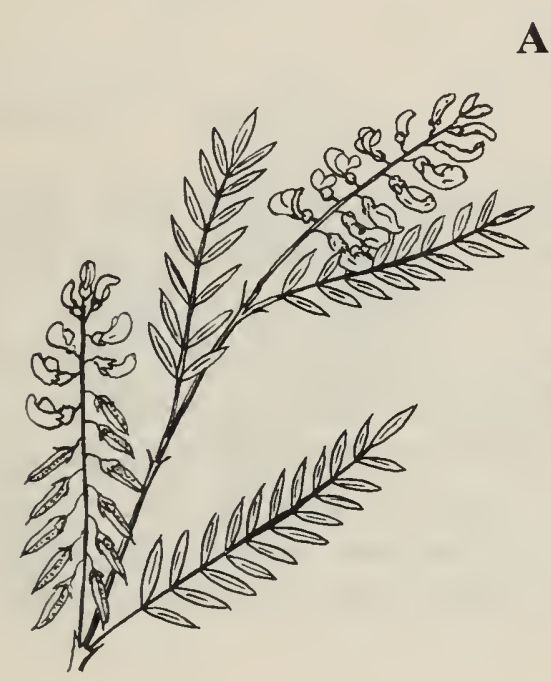

Astragalus bisulcatus (Hook.) A. Gray TWO-GROOVED MILK-VETCH

A stout, many-stemmed perennial, 1 to 3 feet high, with a strong odor. Leaves composed of 17 to 27 elliptic leaflets, each $\frac{3}{8}$ to 1 inch long. Flowers deep purple, $\frac{1}{2}$ inch long, in long dense racemes. Flowers and pods usually drooping. Pods $\frac{1}{2}$ to $\frac{3}{4}$ inch long, with 2 deep grooves. Quite common on prairies and in coulees. May cause selenium poisoning in cattle and sheep. Also a host plant for the caragana blister beetle.

Astragalus pectinatus Dougl.

NARROW-LEAVED MILK-VETCH

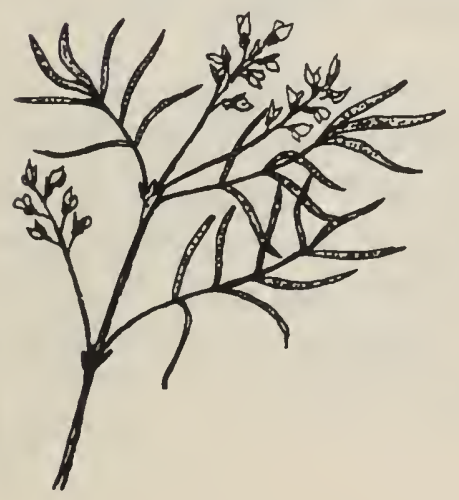

A usually erect, much-branched perennial, 1 to 2 feet high, with leaves of 11 to 21 narrow leaflets $\frac{1}{2}$ to 3 inches long. Flowers creamcolored, $\frac{3}{4}$ to 1 inch long, in conspicuous loose racemes. Flowers usually in June. Common on lighter soils, across southern area on prairies and roadsides. Deep rooted and very droughttolerant. A selenium indicator and also a host plant of the caragana blister beetle. 


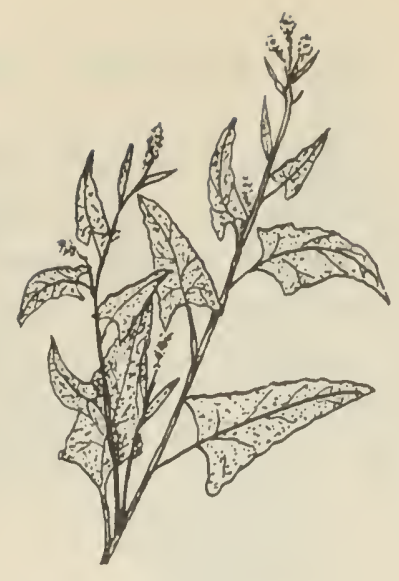

Atriplex hortensis L.

A tall annual, often 4 to 5 feet high. Leaves varying from cordate to triangular to ovate. Two types of seed produced: some brown, large, and flat, about $\frac{1}{8}$ inch across and germinating within a few days, others small, black and shiny, and remaining dormant in the soil for several months. A garden escape, has become quite common.

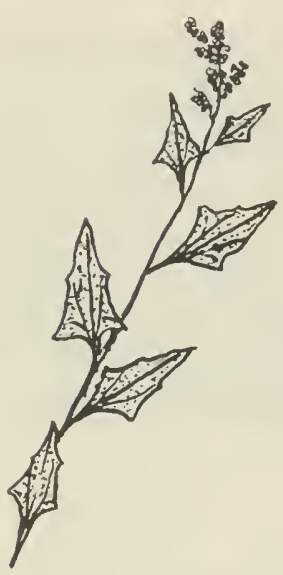

Atriplex patula L.

ORACHE

An annual 1 to 3 feet high, with a grooved, coarse stem. Leaves tapering to their stalks but in the variety hastata (L.) Gray having flatter bases and abruptly narrowed to the stalk. Both common in saline meadows and waste places and easily mistaken for lamb'squarters.

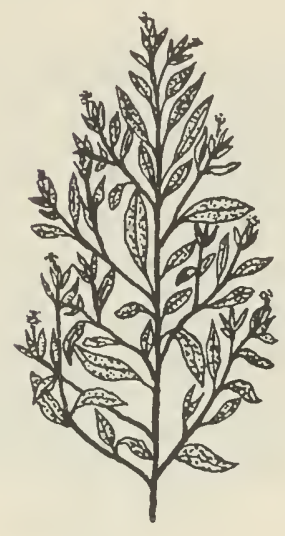

Axyris amaranthoides L.

RUSSIAN PIGWEED

A bushy, erect annual to $2 \frac{1}{2}$ feet high. Stem with many ascending branches. Leaves pale green, lanceolate, to 3 inches long. Flowers in dense leafy clusters, with male flowers towards the stem ends. Producing two types of seeds, the long, winged seeds germinating readily but the small wingless seeds having a long period of dormancy. An introduced weed, very common in cultivated fields and abandoned areas.

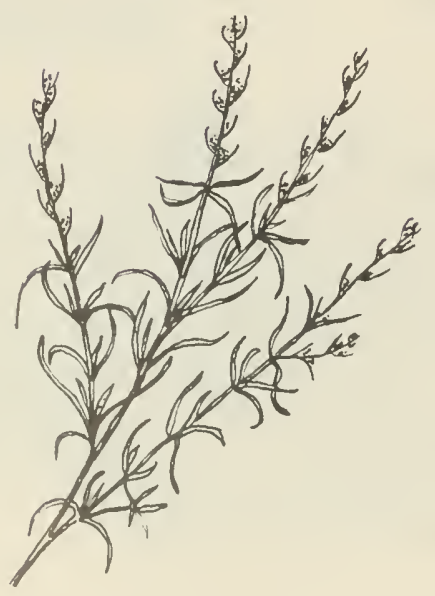

Bassia hyssopifolia (Pall.) Kuntze FIVE-HOOK BASSIA

A slender-stemmed branching annual to 2 feet high. Leaves grayish-green, usually pressed close to stem, linear, $\frac{1}{2}$ to 1 inch long. Flowers tiny, in narrow interrupted spikes. Fruit about the size of a pinhead, enclosed with five small spine-hooked bracts. Appears to be spreading eastward along railway tracks. 

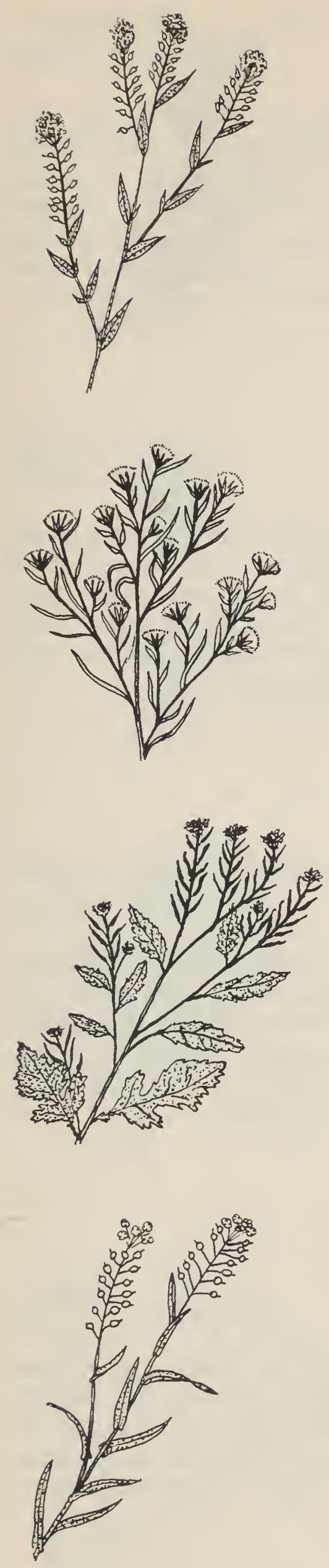

Berteroa incana (L.) DC.

HOARY ALYSSUM

A biennial or perennial, starry-haired, to 2 feet high. Leaves numerous, lanceolate, $\frac{1}{2}$ to 1 inch long. Flowers white, with deeply notched petals. Pods oval, about $\frac{1}{4}$ inch long. An introduced weed, which has been reported from several places.

\section{Brachyactis angusta (Lindl.) Britton RAYLESS-ASTER}

A purple-stemmed, slender, branching annual to 2 feet high. Leaves linear, 1 to 3 inches long, hairless except for some marginal hairs. Flower heads numerous, appearing as tufts of white hair among the leaves. Common in saline soils and moist areas.

Brassica juncea (L.) Cosson

INDIAN MUSTARD

An annual 1 to 4 feet high, with smooth, almost hairless stems and leaves. Lower leaves stalked, 4 to 6 inches long, with large end lobe; upper leaves hardly stalked, much smaller, usually entire. Flowers yellow, Pods 1 to 2 inches long, with a conic beak. A common weed of the fields and waste places.

Camelina microcarpa Andrz.

SMALL-SEEDED

FALSE FLAX

An introduced annual or winter annual with an erect hairy stem 1 to $1 \frac{1}{2}$ feet high. Leaves stalkless, covered with starry hairs. Flowers small, yellow. Pods stalked and ovoid, about $\frac{3}{16}$ inch long, with numerous seeds that have a very short dormancy period. Common in grain fields and waste places. 

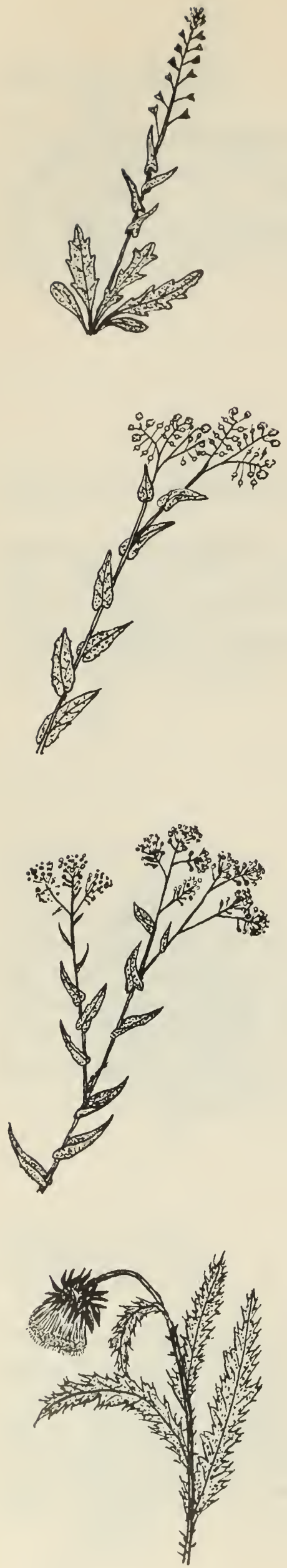

Capsella bursa-pastoris (L.) Medic.

SHEPHERD'S-

PURSE

An introduced annual or winter annual with branched stems to 20 inches high. Basal leaves often deeply cut and lobed, forming a rosette; stem leaves clasping, with eared bases. Flowers small, white, in terminal racemes. Pods triangular and notched at blunt end. Introduced weed, common in gardens and waste places.

Cardaria draba (L.) Desv.

HEART-PODDED

HOARY CRESS

A perennial with deep running roots. Stem leaves alternate, clasping; basal leaves short stalked. Flowers white, in a dense raceme. Seed pods smooth, heart-shaped. Introduced from Europe. Occasionally found in gardens and shelterbelts across the prairies.

\section{Cardaria pubescens (Meyer) Rollins GLOBE-PODDED var. elongata Rollins \\ HOARY CRESS}

A perennial with deep running roots. Basal leaves with short stalks; upper leaves alternate, clasping the stem. Flowers white, in a dense raceme. Seed pods globular, inflated, with fine downy hairs. Introduced, and becoming quite common in gardens and fields.

Carduus nutans L.

NODDING THISTLE

A branching biennial to 3 feet high. Leaves 3 to 6 inches long, deeply divided, very prickly. Flower heads usually purple, nodding, $1 \frac{1}{2}$ to $2 \frac{1}{2}$ inches across, borne singly on long stems. An introduced weed, rather rare in the prairies. 


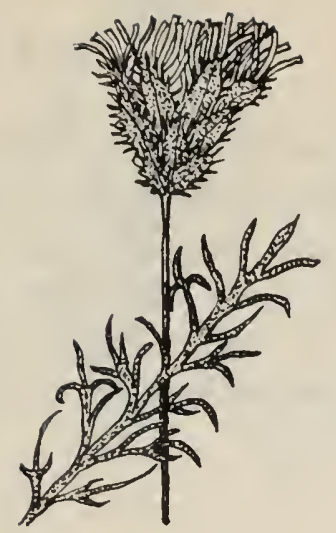

A much-branched annual to 2 feet high, sometimes having a fine spiderweb-like covering on the stems. Leaves once or twice pinnately divided into very narrow segments, some of the uppermost entire. Flowers pale yellowish or cream-colored, numerous, in terminal panicles. Bracts of involucre spiny-margined with a terminal spine. Not yet reported on the prairies but a bad weed in south-central British Columbia.

\section{Centaurea maculosa Lam.}

SPOTTED KNAPWEED

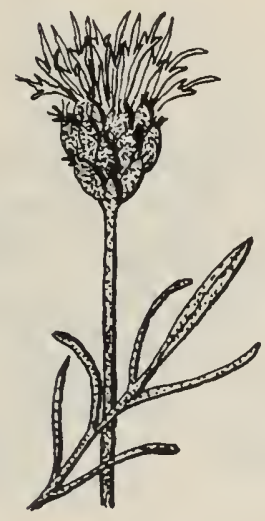

An introduced biennial 1 to 3 feet high. Leaves pinnately divided into narrow lobes, excepting those of the inflorescence, which are smaller and entire. Flower heads purplish or occasionally white, on long stems. Bracts of involucre tipped with a short, dark fringe, not stiff and spiny. A common weed of southcentral British Columbia, may be expected eastwards.

\section{Centaurea repens $\mathrm{L}$.}

RUSSIAN KNAPWEED

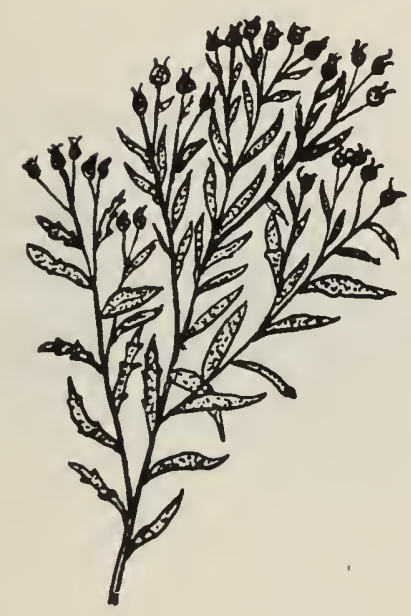

An erect perennial with coarse, woody, running roots, to 3 feet high. Stems ridged and grooved, covered with white woolly hairs when young. Foliage extremely unpleasant to the taste. Flowering heads numerous, in terminal panicles, pale yellowish or cream-colored, about $\frac{3}{8}$ inch long. Flower head bracts with spiny margins and a terminal spine. An extremely persistent, introduced weed, found in fields, shelterbelts, and waste places at various locations.

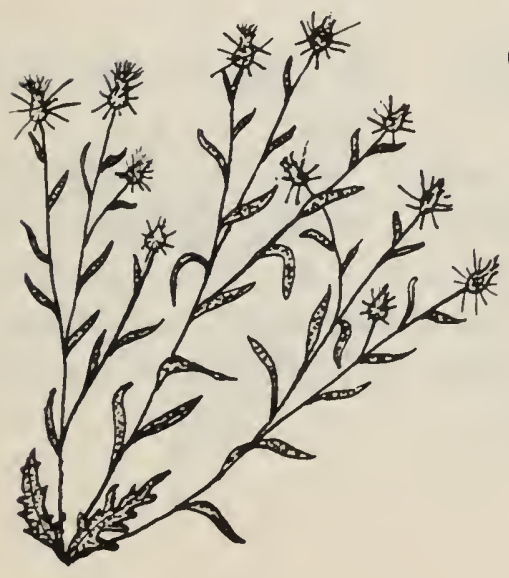

Centaurea solstitialis L.

YELLOW STAR-THISTLE

Annual with branching stem bearing cottony hairs, 1 to 2 feet high. Upper leaves lanceolate to linear, $\frac{1}{2}$ to 1 inch long, entire; basal leaves deeply lobed, to 5 inches long. Bracts often spine-tipped, yellow. Corolla yellow, all florets tubular. An introduced weed, occasionally found in gardens. 


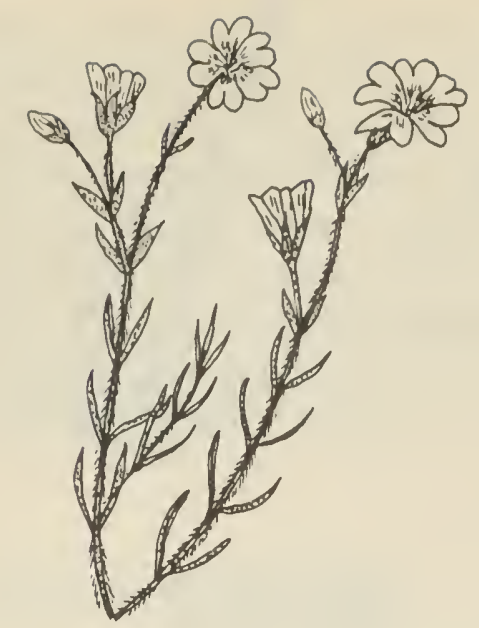

Cerastium arvense $\mathrm{L}$.

A low-growing perennial with opposite, linear to linear-lanceolate leaves, to 8 inches high but with stems often prostrate at base and often with downward-pointing hairs. Flowers white with cleft petals, about $\frac{3}{8}$ inch across. Fruit a long capsule. A very common spring flower on dry prairie in western portion.

Chenopodium album L.

LAMB'S-QUARTERS

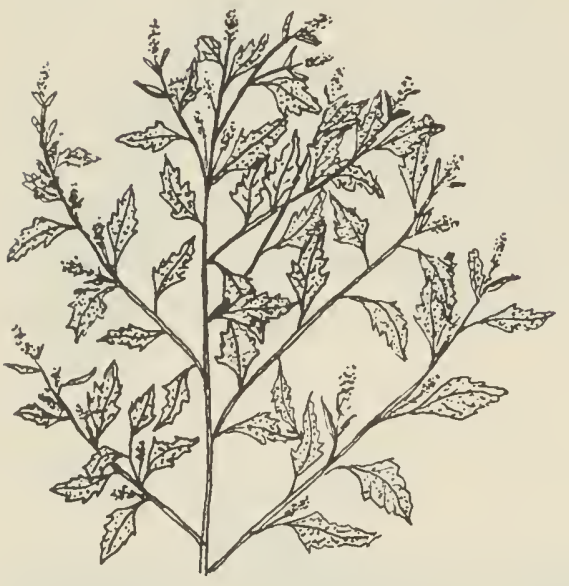

A rank annual 2 to 3 feet high. Leaves alternate, with wavy margins, mealy coated, to 3 inches long. Stems usually grooved, with reddish lines and blotches. Flowers in dense panicles in leaf axils and at summit of stem. One of the commonest weeds in our area. Young plants often eaten as greens.

\section{Chenopodium rubrum L.}

RED GOOSEFOOT

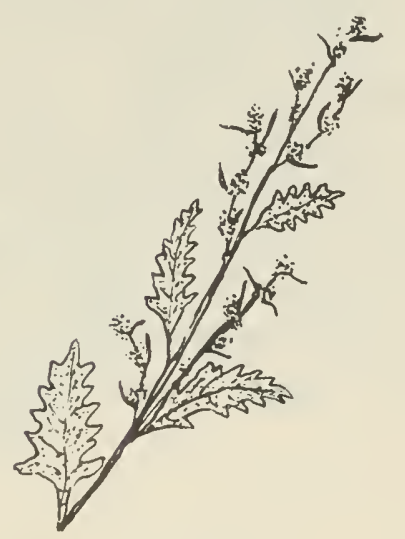

A tall annual to $2 \frac{1}{2}$ feet high, with ascending branches. Leaves thick, dark-green, not mealy, coarsely toothed, pointed at both ends, to 4 inches long. Flower clusters in leafy spikes in the axils of the leaves, turning dull-red when in fruit. Common on moist saline soils.

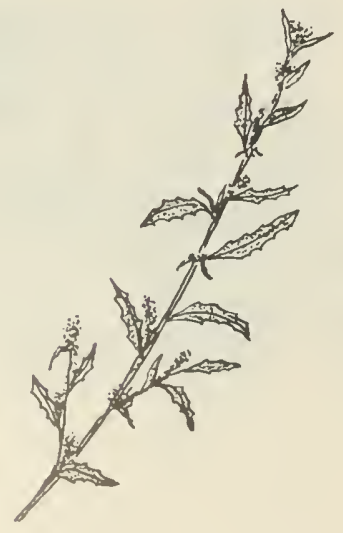

Chenopodium salinum Standl. SALINE GOOSEFOOT

A low prostrate annual with fleshy, reddish stems. Leaves alternate, small, triangular to oval or oblong, lobed, mealy on under surface, $\frac{1}{2}$ to 1 inch long, resembling small oak leaves. Flowers in small spikes in leaf axils. Common in moist saline areas. 


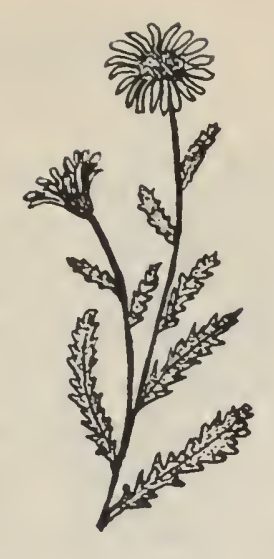

Chrysanthemum leucanthemum L.

An erect perennial to 2 feet high. Lower leaves stalked, obovate to spatulate, toothed, 1 to 3 inches long; upper leaves not stalked, clasping, oblong, toothed near base. Flower heads borne singly at end of stem, 1 to 2 inches across, with yellow ray florets and white disk flowers. Introduced, occasionally found as a garden escape in meadows and moist roadsides.

\section{Cichorium intybus L.}

CHICORY

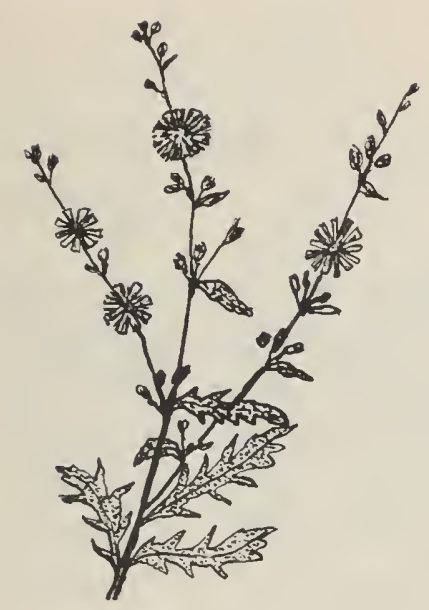

A perennial with a long, thick, deep root and branching, hairy stems 2 to 3 feet high. Leaves mostly basal, usually spatulate but deeply toothed or pinnatifid, with backward-pointing lobes, to 6 inches long; upper stem leaves small, lanceolate, stalkless, entire or lobed. Flowers bright blue, about 2 inches across, in clusters of 3 or 4 without stalks, at intervals along the upper leafless part of stems. Fairly common introduced weed of southeastern prairies but scarcer in the west.

\section{Cicuta douglasii (DC.) Coult. \& Rose WESTERN} WATER HEMLOCK

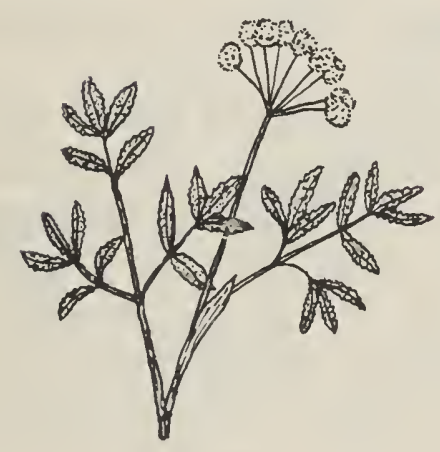

A stout-stemmed, much-branched perennial to 6 feet high, from a swollen, bulbous rootstock, which is divided horizontally into chambers. Leaves double-pinnate, with lanceolate to linear-lanceolate leaflets 2 to $3 \frac{1}{2}$ inches long, sharply toothed. Base of leafstalk swollen and sheathing the stem. Flowers small, white, in compound umbels. Common in wet and marshy areas. Very poisonous to stock and humans.

Cirsium arvense (L.) Scop.

CANADA THISTLE

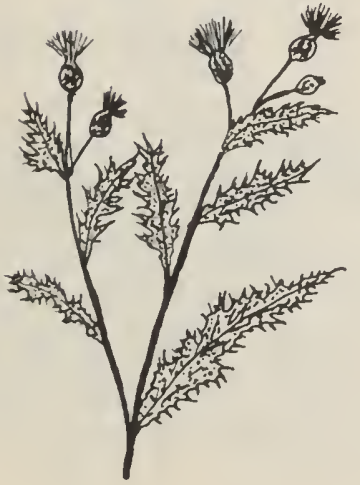

A persistent perennial with deep running rootstocks, usually growing in large patches. Upper leaves stalkless, clasping the stem, 2 to 5 inches long, deeply cut into prickly, toothed segments; basal leaves sometimes stalked. Flower heads with purple, occasionally white, florets. A common introduced weed across the prairies. 


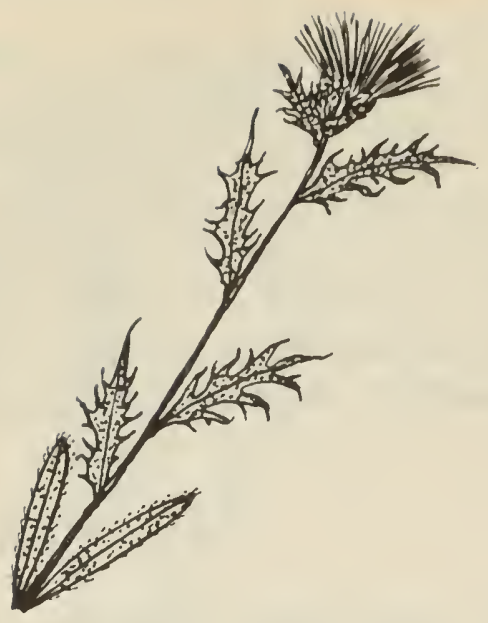

A perennial $1 \frac{1}{2}$ to 3 feet high, from a deep root. Stem slender, usually branched, covered with loose cottony hairs. Leaves 2 to 6 inches long, deeply cleft into lanceolate spiny lobes. Flower heads rose to rose-purple, $1 \frac{1}{4}$ to $1 \frac{1}{2}$ inches across. Resembles $C$. undulatum except that its newer basal leaves are often entiremargined and there are numerous new shoots around the base of the older plant. Not common, on moist prairie and valleys of southern and western areas.

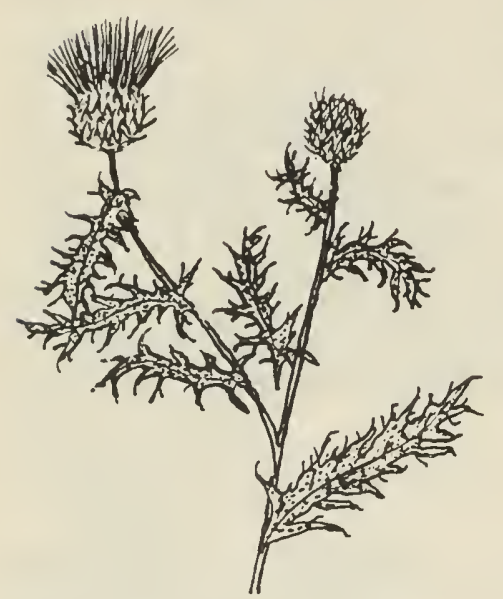

Cirsium undulatum (Nutt.) Spreng.

WAVY-LEAVED THISTLE

A white-woolly biennial 1 to 3 feet tall, with stout, branched, leafy stem. Leaves oblong or lanceolate, with triangular lobes and very prickly; lower leaves stalked, upper ones stalkless, often continuing partway down the stem. Purple or pink flower heads single, at ends of branches, $1 \frac{1}{2}$ to 3 inches across. Very common in southern and western portions.

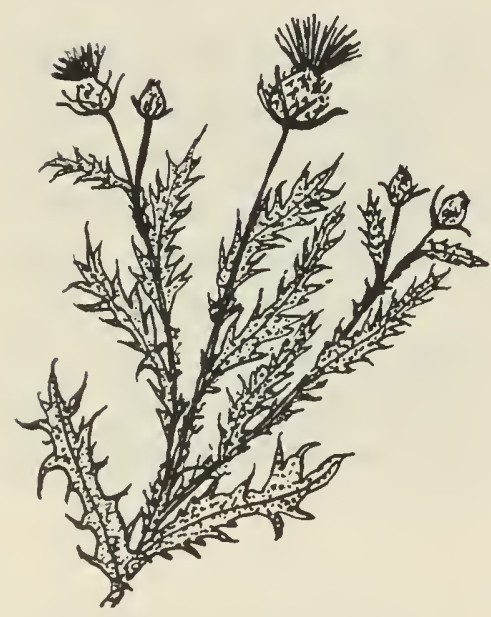

Cirsium vulgare (Savi) Tenore

BULL THISTLE

A stout-stemmed, woolly biennial 3 to 5 feet tall, branched and leafy up to the heads. Leaves dark-green, 3 to 6 inches long, hairy on both sides, deeply cleft, very prickly. Flower heads numerous, purple, at end of branches. Involucral bracts cobwebby, spine-tipped. Introduced, occasionally found on waste land throughout central and southern portions of the area.

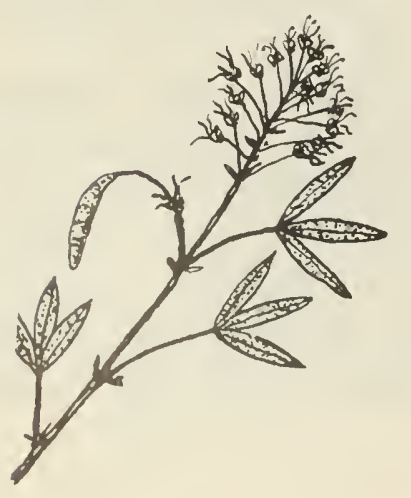

Cleome serrulata Pursh

SPIDERFLOWER

An erect, branching annual 1 to 3 feet high, with smooth, hairless stems. Leaves trifoliolate, with lanceolate leaflets 1 to 3 inches long. Flowers usually pale-pink, occasionally white. Seed pods 1 to 2 inches long, slightly curved. Strong-smelling plant, very common along roadsides on light soils in southern portions. 


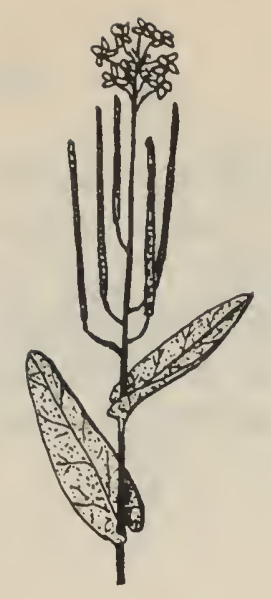

Conringia orientalis (L.) Dum.

HARE'S-EAR

MUSTARD

An introduced annual or winter annual to 2 feet high, with taproot and smooth stems. Leaves elliptical, entire, smooth, clasping stem with eared bases. Plant has a bluish bloom. Flowers creamy-white. Pods narrow, erect, 3 to 4 inches long, square in cross section. A common weed of fields and roadsides.

Convolvulus arvensis $\mathrm{L}$.

FIELD BINDWEED

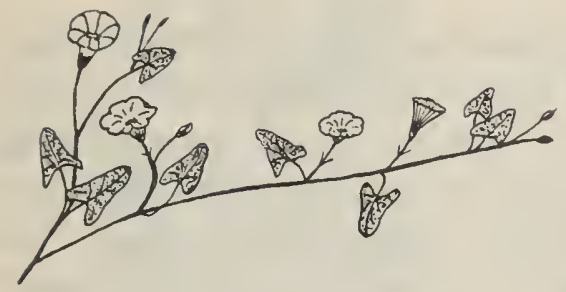

A deep-rooted perennial with a very extensive system of white roots and slender, twining stems. Leaves alternate, bluntly triangular, with hastate bases. Flowers pink to white, about 1 inch across, singly or in small bunches of 2 or 4 . Fruit a 2-celled capsule containing large, dark-brown, angular seeds. An introduced weed, very difficult to eradicate.

Convolvulus sepium L.

WILD MORNING-GLORY var. americanus Sims

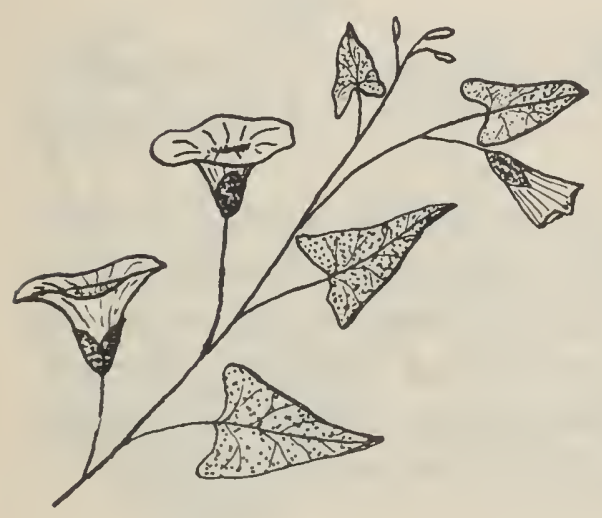

A native twining perennial with broadly hastate leaves, which are alternate, simple, and long stalked. Flowers funnel-shaped, white or pink, large, with two large clasping bracts, borne in axils of leaves. Seeds have a long dormant period and may remain viable in the soil for many years even under favorable germinating conditions. Found along water courses and in moist places throughout area.

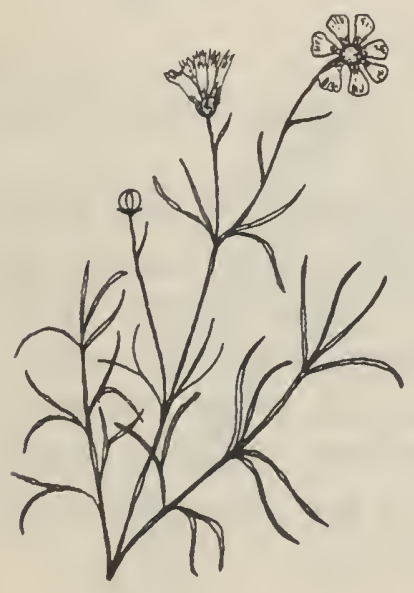

Coreopsis tinctoria Nutt.

COMMON TICKSEED

A much-branched annual with a slender hairless stem 1 to 3 feet high. All leaves except the very uppermost divided once or twice into linear segments; lower leaves sometimes stalked. Flower heads numerous, with yellow ray florets and brownish disk florets. Seeds resemble small insects. Common in low moist areas. Often used as a garden flower. 


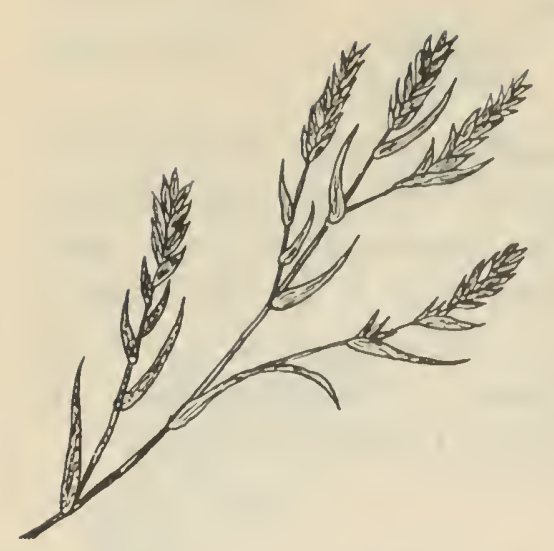

Corispermum hyssopifolium L.

BUGSEED

A much-branched annual to $1 \frac{1}{2}$ feet high. Leaves narrow, linear, $1 \frac{1}{2}$ to 2 inches long, pale-green. Flowers in clusters in axils of leaves. Seeds small, medium brown, flattened, with a decided wing around the edges. Not very common, on sandy soils in southwest and southcentral area.

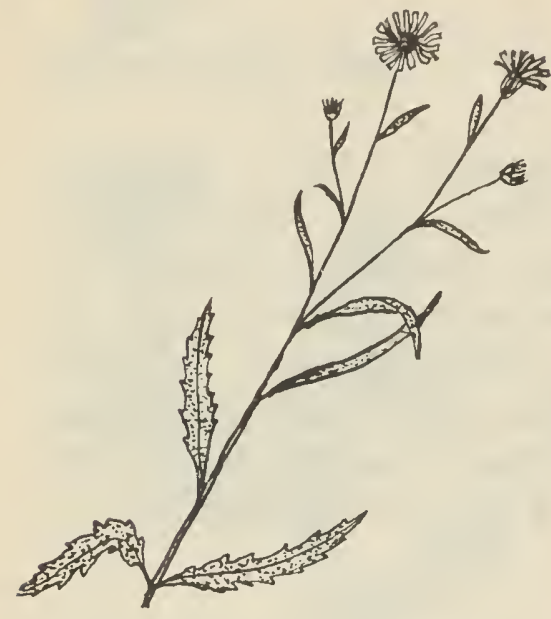

Crepis tectorum L.

NARROW-LEAVED

HAWK'S-BEARD

An introduced annual with slender, branched, leafy stem 6 to 18 inches high, with milky juice. Basal leaves 4 to 6 inches long, usually with backward-pointing teeth; stem leaves stalkless, linear. Flower heads numerous, yellow, on long stems. Rapidly becoming a serious weed on light soils in the northern and eastern parts.

\section{Cryptantha fendleri (A. Gray) Greene FENDLER'S CRYPTANTHE}

A very hairy, gray or whitish annual in thick groups, short, to 8 inches high. Leaves linear, 1 to $2 \frac{1}{2}$ inches long. Flowers small, white, in scorpioid clusters at ends of branches. Fruits 4 smooth, shiny, brown nutlets. Common on sand dunes and light soils of southwest.

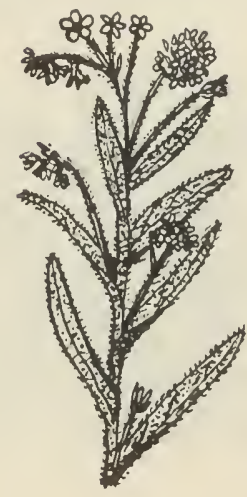

Cynoglossum officinale L.

HOUND'S-TONGUE

A soft-hairy biennial to 3 feet high, with erect, leafy stems. Lower leaves oblong-lanceolate, slender-stalked, 6 to 12 inches long; upper leaves without stalks or clasping and lanceolate. Fiowers purplish-red, in scorpioid racemes. Fruit a pyramid of 4 nutlets. An introduced weed occasionally found in pastures and waste places in the southeastern areas. 


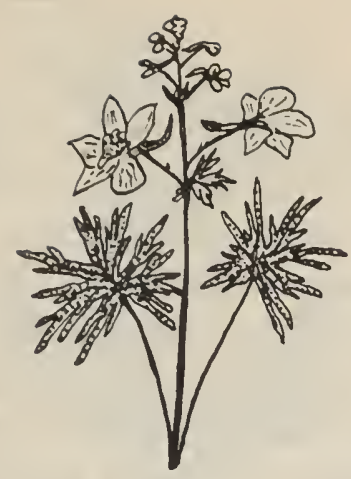

Delphinium bicolor Nutt.

A perennial with a thick, fleshy, fibrous root and hairy stems $\frac{1}{2}$ to 2 feet high. Leaves alternate, on long stalks, finely hairy, much cleft and dissected. Flowers spurred, dark-blue, in loose terminal racemes on long stalks. Fruit a dry follicle with many seeds. Not common but abundant locally in the southwest. Very poisonous to cattle, but appears harmless to sheep.

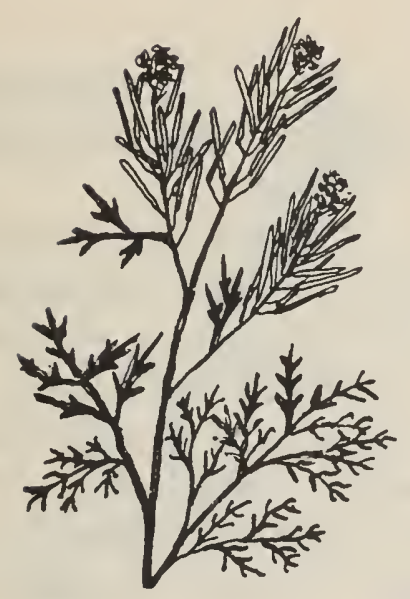

Descurainia sophia (L.) Webb

FLIXWEED

Annual or biennial from a taproot, branched, with leaves 2 to 3 times dissected and with some star-like hairs. Flowers yellow. Pods $\frac{3}{8}$ to $1 \frac{1}{8}$ inch long, linear, on short stalks at right angles to the stem. Introduced, and now one of our most common weeds.

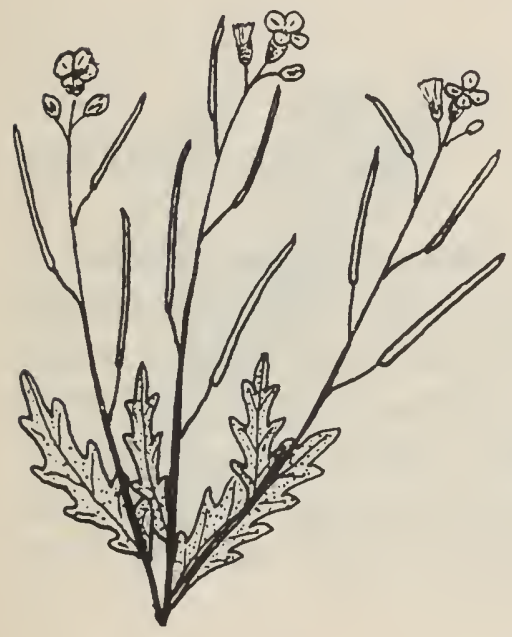

Diplotaxis muralis (L.) DC.

SAND-ROCKET

An annual branched from base, 1 to 2 feet high. Stems leafy only near base, with oblanceolate, lobed leaves 2 to 4 inches long, usually with a slender stalk. Flowers yellow. Pods $\frac{3}{4}$ to 1 inch long, stalked, with a short beak. Introduced, occasionally found in waste places.

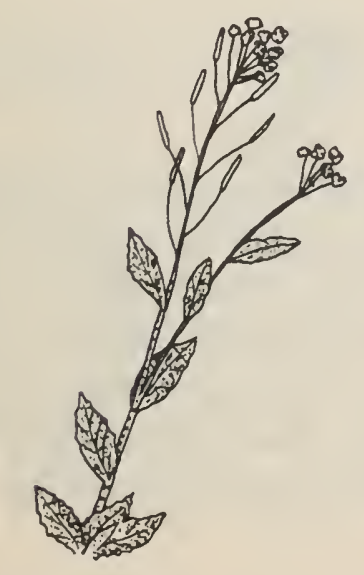

Draba nemorosa L.

WOOD WHITLOW-GRASS

A low, tufted, winter annual 6 to 12 inches high, from a rosette of basal leaves, with a few stem leaves. Flowers small, pale-yellow, occasionally fading to white, borne in a raceme. Seed pods stalked, oval, $\frac{1}{4}$ to $\frac{1}{3}$ of an inch long. Quite common throughout the area. 


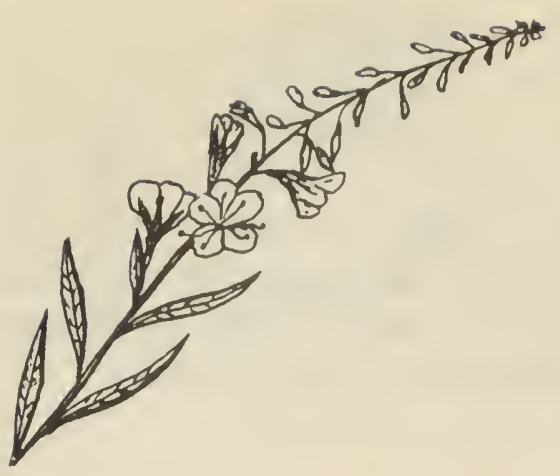

A stout perennial with alternate, shortstalked, entire, lanceolate leaves 2 to 6 inches long, with lateral veins near margins. Flowers pink to purple, in long terminal racemes, with a small bract beneath each flower stalk. Fruit a 4-angled capsule 2 to 3 inches long, which splits lengthwise to release numerous tufted seeds. Common in woodlands and burnt-over forests, occasionally in moist places on open prairie.

Epilobium glandulosum Lehm.

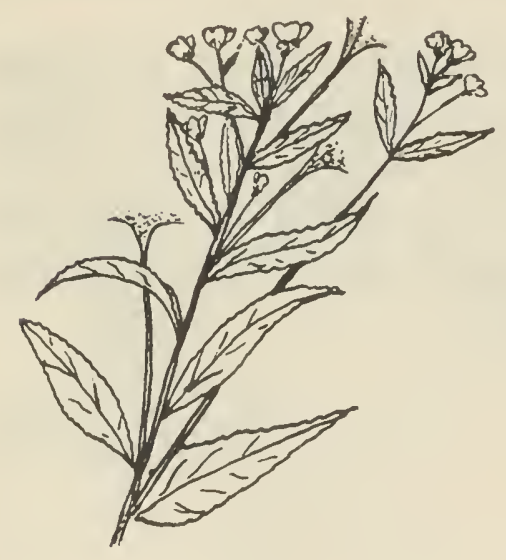

var. adenocaulon (Haussk.) Fern.

NORTHERN

WILLOWHERB

An erect perennial 1 to 3 feet high, sometimes sticky. Leaves mostly opposite, lanceolate or ovate-lanceolate, 1 to $2 \frac{1}{2}$ inches long. Flowers pink, usually nodding when young, about $\frac{1}{4}$ inch long, with a long ovary tube beneath the flower. Fruit a many seeded capsule $1 \frac{1}{2}$ to 2 inches long, which splits lengthwise when ripe, releasing many tufted seeds. Common in sloughs and wet places.

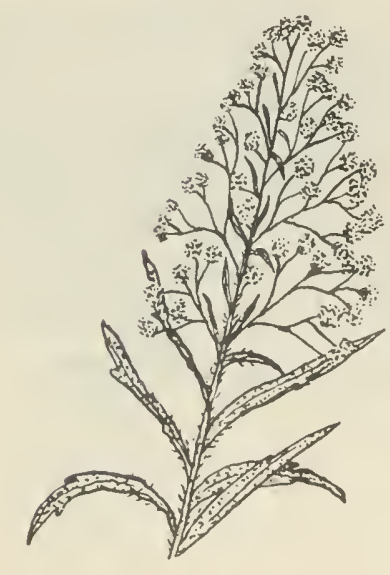

Erigeron canadensis L.

CANADA FLEABANE

A slender, bristly, hairy-stemmed annual 4 inches to 5 feet high, usually much branched toward the top. All leaves hairy; upper small, linear, entire, stalkless; lower ones 1 to 4 inches long, spatulate, slightly toothed, short-stalked. Flower heads numerous, in a large, open panicle. A common native weed of fields and dry soils.

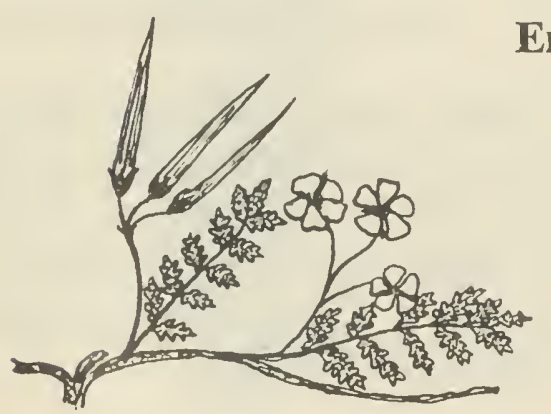

Erodium cicutarium (L.) L'Her.

STORK'S-BILL

A low, prostrate annual with pinnately divided leaves and stipules. Flowers pink or purplish, in clusters on long stalks, about $\frac{3}{8}$ inch across, the long style splitting from the base upwards into 5 segments, each with a single-seeded capsule bearing a long spiral tail. Occasionally found around towns in south and eastern areas. 


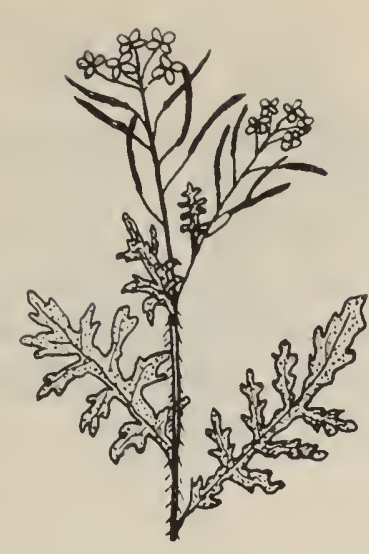

Erucastrum gallicum (Willd.) O. E. Schulz

DOG

An erect annual 8 to 18 inches high, with downward-pointing stem hairs. Leaves alternate, varying to 10 inches long, deeply cut, often to midvein, making them appear pinnate. Flowers pale-yellow. Seed pods linear, circular in cross section, 1 to $1 \frac{1}{2}$ inches long, with short stalks and a slender style. An introduced weed becoming plentiful.

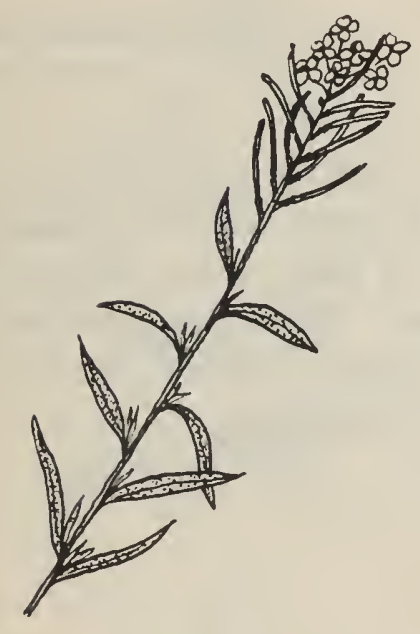

Erysimum asperum (Nutt.) DC.

\section{WESTERN \\ WALLFLOWER}

A rough, usually straggling, biennial 1 to 3 feet high, coarse, much branched, with oppressed small white hairs. Flowers pale-yellow, $\frac{1}{2}$ inch across. Pods $1 \frac{1}{2}$ to 4 inches long, spreading in all directions from the stem, narrow, rough, 4-angled, with a thick style at the end and a short, stout stalk. Common in the south on light and sandy soils, rare to the north.

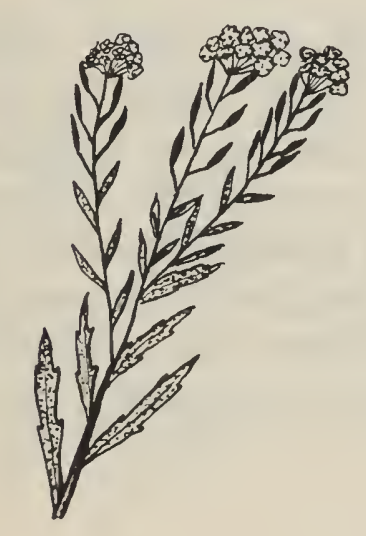

Erysimum cheiranthoides L. WORMSEED MUSTARD

Annual or winter annual to 2 feet high, with lanceolate or oblong-lanceolate, dark-green leaves 1 to 4 inches long. Flowers small and yellow, in dense terminal clusters. Seed pods linear, $\frac{1}{2}$ to 1 inch long on slender stalks. A weed of fields and moist places, not very common.

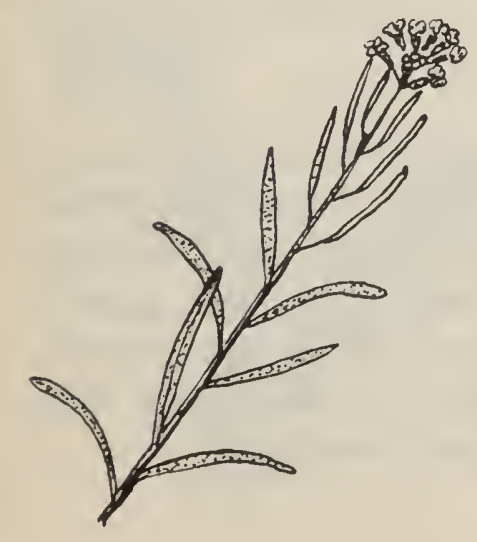

Erysimum inconspicuum (S. Wats.) MacM. SMALLFLOWERED

PRAIRIE-ROCKET

An erect, grayish-green perennial 1 to 2 feet high. Leaves narrow, 1 to 3 inches long, the upper stalkless, the lower ones stalked. Flowers $\frac{1}{4}$ inch across, yellow, borne on top of stem. Common on dry sandy prairie throughout southern portions. 

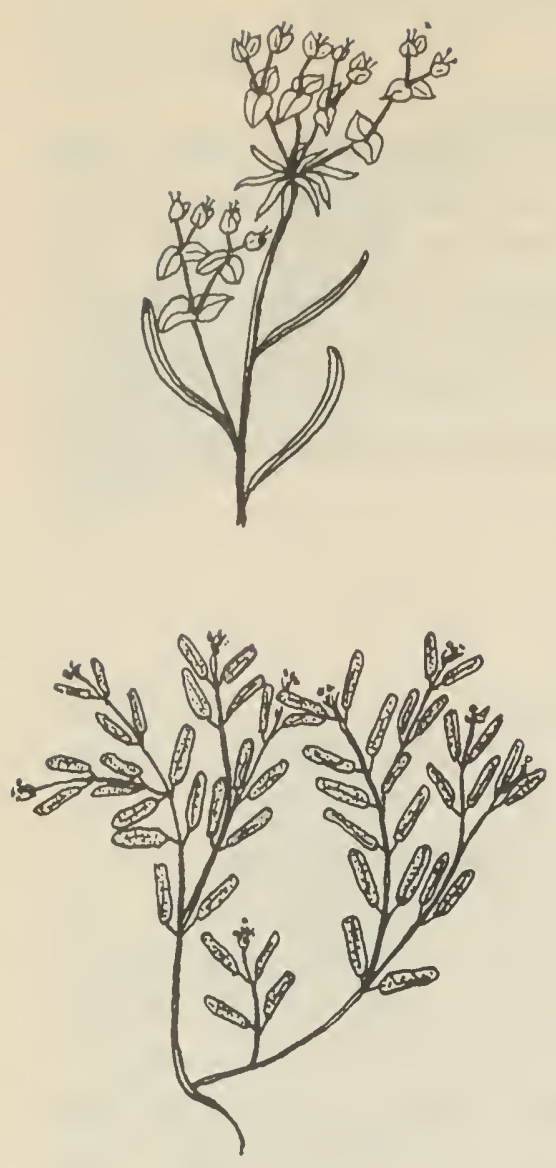

Euphorbia glytosperma Engelm.

RIDGE-SEEDED SPURGE

A flat, mat-forming annual 2 to 15 inches across, with a milky sap. Leaves opposite, small, pale-green, oblong, $\frac{1}{8}$ to $\frac{1}{2}$ inch long. Flowers small, in axils of leaves. Seeds ashy-white, strongly wrinkled. A common native plant in waste places and around buildings.

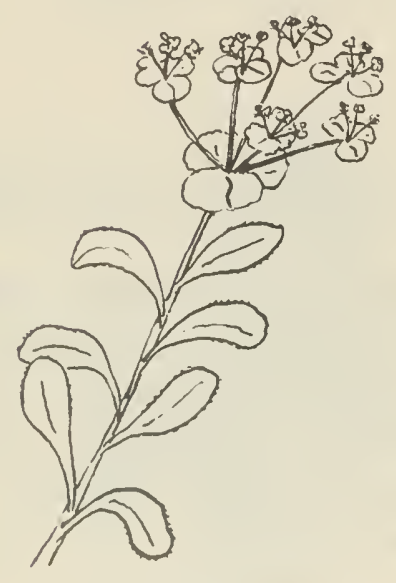

Euphorbia helioscopia L.

SUN SPURGE

An erect, introduced annual with a milky sap, 6 to 24 inches high, often branching from base. Leaves alternate, obovate or spatulate, bluntly rounded at tip, narrowed to base, $\frac{3}{4}$ to 2 inches long. Flowers in terminal umbel. Fruit a smooth capsule containing dark orange-brown seeds with a ridge down one side. Cultivated fields and gardens, but not common.

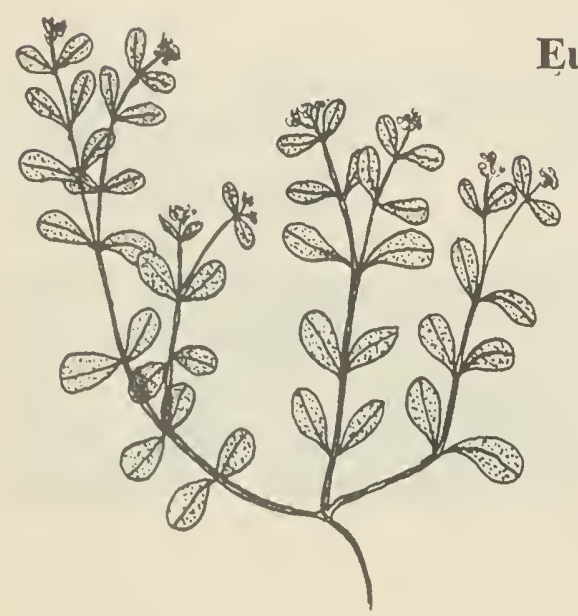

Euphorbia serpyllifolia Pers.

THYME-LEAVED SPURGE

A native annual, usually forming flat mats up to $1 \frac{1}{2}$ feet across. Stems usually smooth, somewhat reddish, with a milky sap. Leaves opposite, small, $\frac{1}{8}$ to $\frac{1}{2}$ inch long, dark-green, with a prominent red line down the center. Flowers small, in leaf axils. Common on dry soils and waste places across prairies. 


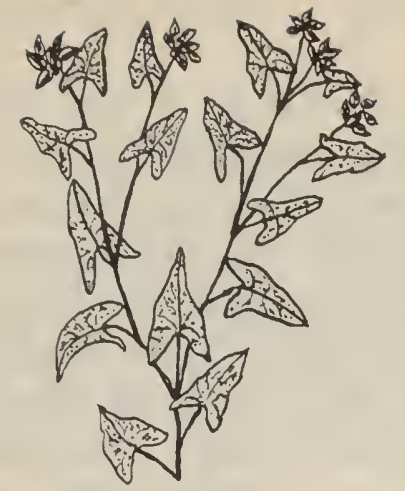

Fagopyrum tataricum (L.) Gaertn.

TARTARY

BUCKWHEAT

Annual with alternate, entire leaves, roughly triangular, 1 to 4 inches long. Flowers small, white, in bunches on flowering stems arising from leaf axils. Seeds about size of wheat kernel. Introduced, a serious pest in northern and central Alberta.

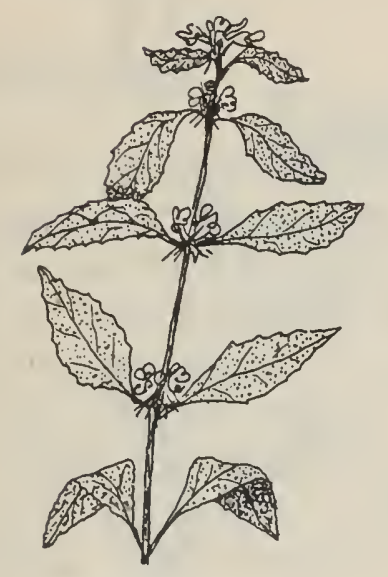

Galeopsis tetrahit L.

HEMP-NETTLE

A hairy, rough annual 1 to 3 feet high. Stems usually swollen below nodes. Leaves 2 to 4 inches long, ovate and coarsely toothed. Flowers in both terminal and axillary clusters, with sharp needle-pointed calyx teeth. Petals $\frac{5}{8}$ to 1 inch long, purple or pink variegated with white. Seeds egg-shaped, $\frac{1}{8}$ inch long, grayishbrown. Introduced from Europe, a bad weed in northern and eastern portions where moisture conditions are favorable.

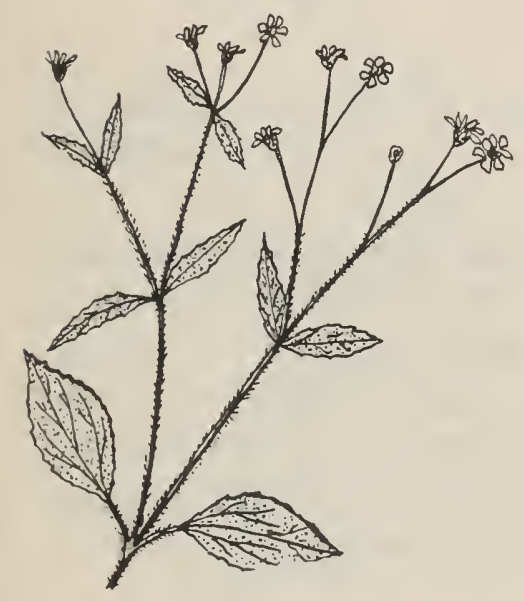

Galinsoga ciliata (Raf.) Blake

GALINSOGA

A much-branched, erect or spreading annual 1 to 2 feet high, stems often rooting at nodes. Leaves opposite, stalked, ovate, with rounded teeth, $\frac{1}{2}$ to 2 inches long. Flower heads many, both terminal and in leaf axils, $\frac{1}{8}$ to $\frac{1}{4}$ inch across, with 4 or 5 small ray florets. Introduced from South America, a garden weed in southeastern part of prairies.

Glecoma hederacea L.

GROUND-IVY

A creeping perennial with dull greenishpurple stems 1 to $1 \frac{1}{2}$ feet long, which root at nodes. Leaves ovate-rounded, cordate based, $\frac{1}{2}$ to $1 \frac{1}{2}$ inches across, often with a purplish tinge. Flowers light blue, $\frac{5}{8}$ to $\frac{3}{4}$ inch long, in clusters of 2 or 3 in leaf axils. An introduced plant becoming common in waste areas in eastern parts and as a garden weed elsewhere. 


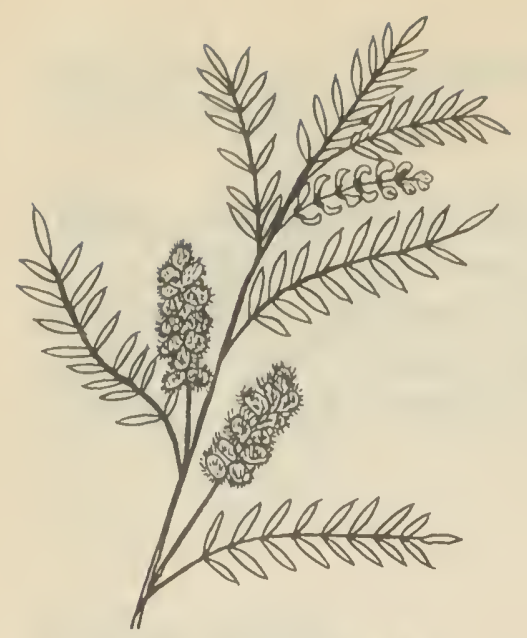

Glycyrrhiza lepidota (Nutt.) Pursh

An erect, branching plant 1 to 3 feet high, from a thick, sweet-tasting rootstock that has a slight licorice flavor. Leaves of 11 to 19 lanceolate or oblong, pale-green, glandular-dotted leaflets, $\frac{3}{4}$ to $1 \frac{1}{4}$ inches long, pointed at each end. Flowers yellowish-white, $\frac{1}{2}$ inch long, in dense racemes from leaf axils. Fruit an oblong, reddish-brown pod, $\frac{1}{2}$ inch long, with long, hooked prickles. Common in low spots and coulees in southern prairies, rarer to the north.

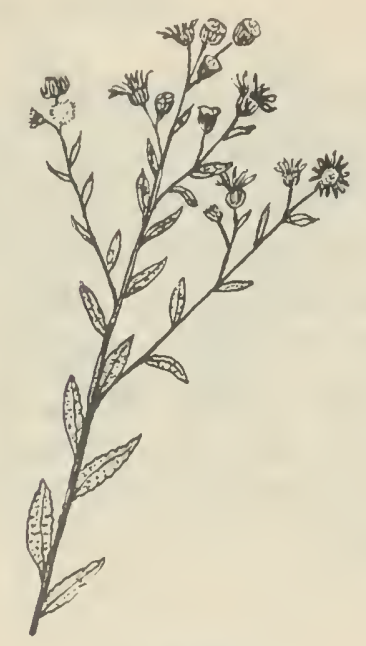

Grindelia perennis A. Nels.

GUMWEED

A branched biennial or perennial with smooth stems 8 to 24 inches high. Leaves alternate $\frac{1}{2}$ to $1 \frac{1}{2}$ inches long, oblanceolate, hairless, with fine close teeth, stalkless. Flower heads $\frac{3}{4}$ to $1 \frac{1}{4}$ inches across, borne in large numbers at ends of stems. Ray florets bright-yellow. Bracts in many series, very sticky and gummy. Achenes or seeds bearing 2 or 3 awns. Common on dry prairies, roadsides, and slough margins.

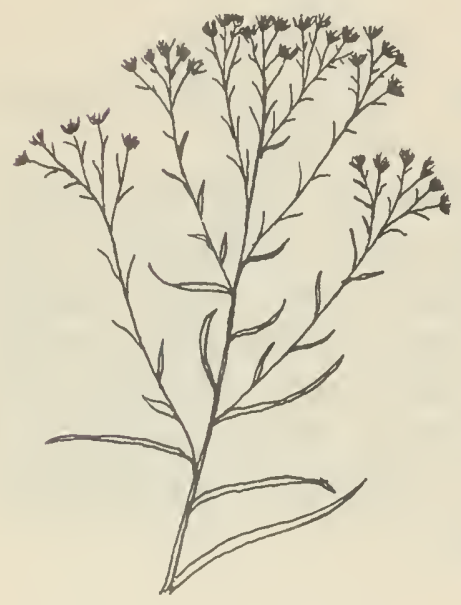

Gutierrezia diversifolia Greene COMMON
BROOMWEED

An erect, deep-rooted, many-stemmed perennial 4 to 8 inches high. Leaves stalkless, numerous, narrowly linear, entire, $\frac{1}{2}$ to $1 \frac{1}{2}$ inches long. Flowers many, small, in close clusters at ends of branches. Not relished by livestock, increasing with overgrazing. Common on dry prairies, extremely drought tolerant.

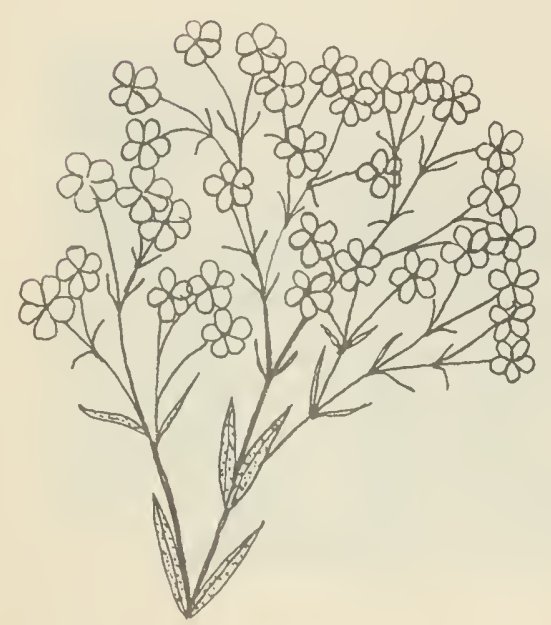

Gypsophila elegans Bieb.

ANNUAL BABY'S-BREATH

A much-branched annual 1 to $1 \frac{1}{2}$ feet high, with narrow, lanceolate leaves. Flowers white, numerous, $\frac{1}{2}$ inch across. Petals longer than sepals. A garden escape sometimes found in waste places. 


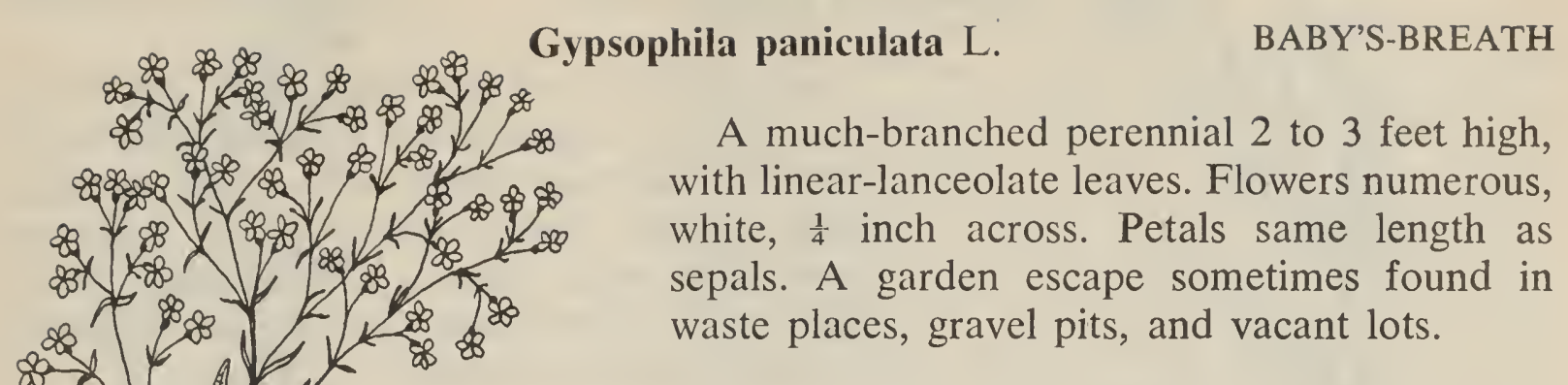

Haplopappus spinulosus (Pursh) DC.

SPINY

IRONPLANT

A much-branched perennial from a thick, woody root, 6 to 18 inches high. Leaves $\frac{1}{2}$ to $1 \frac{1}{2}$ inches long, bluish-green, often finely hairy, deeply dissected into narrow segments, which have bristle-pointed teeth. Heads $\frac{1}{4}$ to $\frac{3}{4}$ inch across, numerous, with narrow ray florets. Common on dry hillsides and prairie in southwest.

Helenium autumnale L. var. montanum (Nutt.) Fern.

MOUNTAIN

SNEEZEWEED

A perennial with an erect, stout stem 1 to $2 \frac{1}{2}$ feet tall. Leaves $1 \frac{1}{2}$ to 4 inches long, lanceolate, sometimes slightly toothed, stalkless, continuing down the sides of the stem. Numerous flower heads $\frac{3}{4}$ to $1 \frac{1}{2}$ inches across, with high, rounded, yellow centers and yellow ray florets to $\frac{1}{2}$ inch long. Common in low places throughout western portions, thought to be poisonous to livestock and to produce a taint in milk.

Helianthus lenticularis Dougl. SHOWY SUNFLOWER

A tall, stout-stemmed annual 3 to 6 feet high. Stems rough, often with short, bristly hairs. Leaves coarsely toothed, alternate, ovate, often with cordate bases, 4 to 8 inches long. Heads 3 to 6 inches across, with dark-brown or purple center. Common on clay and heavier soils and along roadsides in southwest. 


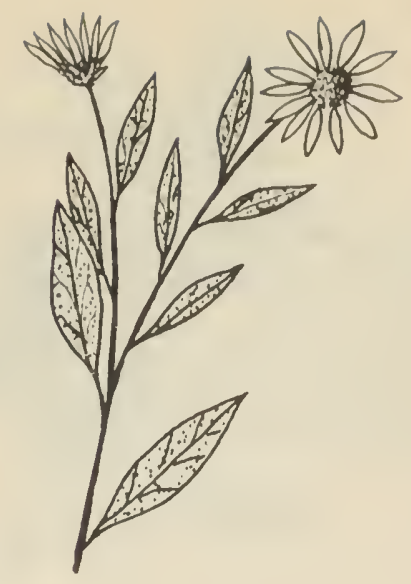

Helianthus petiolaris Nutt.

An annual 1 to 3 feet high, with stiff hairy stems. Leaves long-stalked, 1 to 3 inches long, ovate to ovate-lanceolate, with entire margins, rough on both sides. Heads $1 \frac{1}{2}$ to 3 inches across with small, brown, raised center. Very similar to $H$. lenticularis. Only found on sandy soils and roadsides in sandy areas.

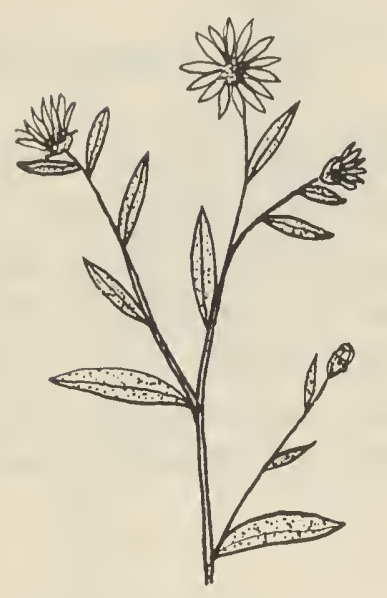

Helianthus subtuberosus Bourgeau TUBEROUS-ROOTED

SUNFLOWER

A perennial with creeping rootstocks, often with spindle-shaped, fleshy roots, 3 to 10 feet high. Leaves stalkless or very short stalked, lanceolate, 2 to 6 inches long, narrow, very rough on both sides. Heads on long stalks, $1 \frac{1}{2}$ to $2 \frac{1}{2}$ inches across, with yellowish center. Common in moist saline soils, especially in southern areas.

Heliotropium curassavicum L. var. obovatum DC.

SPATULATE-LEAVED HELIOTROPE

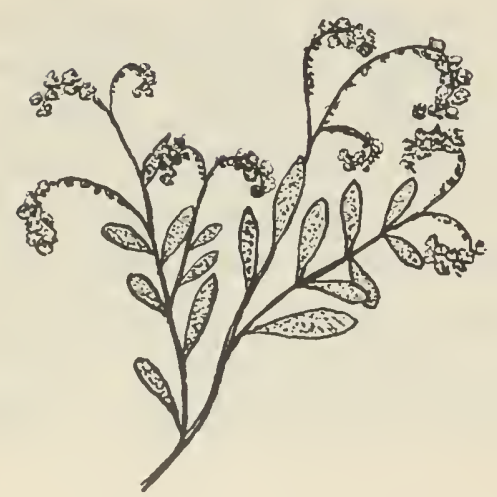

A perennial from thick, fleshy, white, running roots, 12 inches high. Plants smooth, with a slight bloom giving a waxy appearance. Leaves fleshy, spatulate, with distinct veins, $\frac{3}{4}$ to 2 inches long. Flowers $\frac{1}{4}$ inch across, white or with a bluish tinge, at the end of branches, in several scorpioid spikes $\frac{1}{2}$ to 4 inches long. Found in saline slough margins in southwest but not generally common.

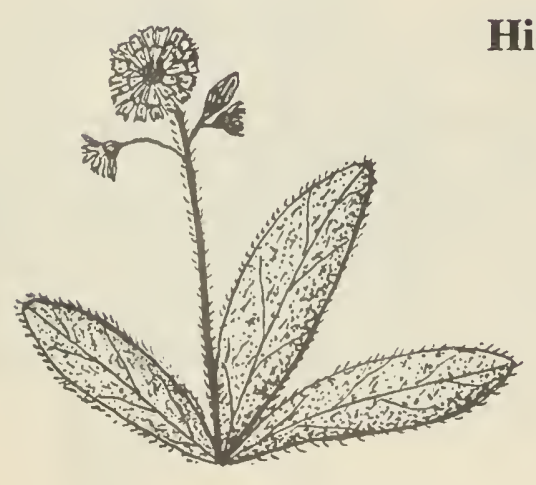

Hieracium aurantiacum L.

ORANGE HAWKWEED

A perennial with slender running roots, 6 to 20 inches high, glandular hairy. Basal leaves hairy, spatulate, 2 to 5 inches long. Stem sometimes bearing several small alternate leaves. Flowers orange-red, in a cluster $\frac{3}{4}$ to 1 inch across. Has been found near Winnipeg but rare elsewhere, although quite common in Eastern Canada. 

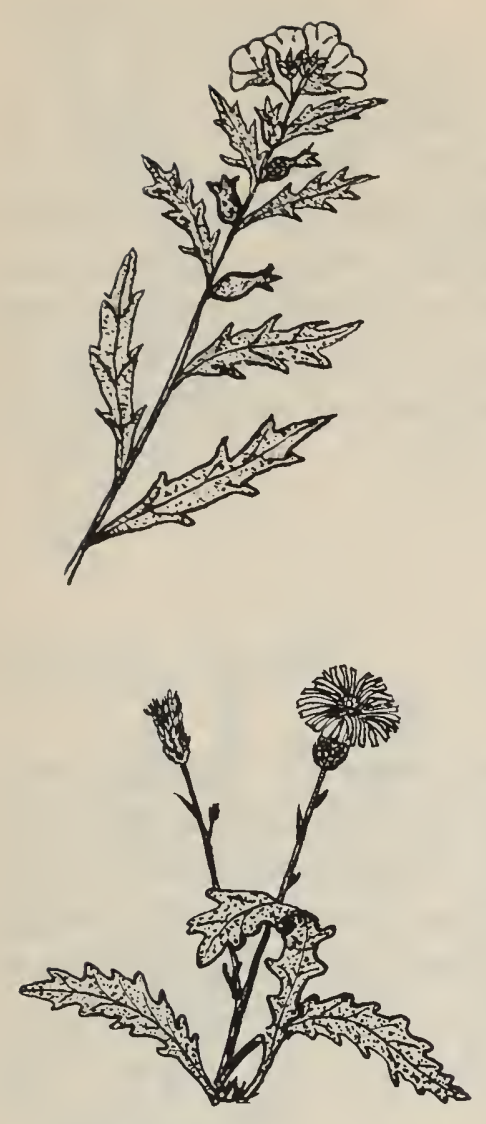

Hypochoeris radicata L.

A perennial with basal rosette of somewhat hairy leaves 2 to 6 inches long, oblanceolate, with backward-pointing lobes. The few stem leaves scale-like. Flower heads 3 to 4, yellow, stalked, about 1 inch across, at the summit of the 8- to 18-inch stems. Introduced and only rarely found.

Iva axillaris Pursh

POVERTYWEED

A herbaceous perennial 2 feet high, with woody, running roots. Leaves stalkless, entire, 3 -nerved, obovate to linear-oblong, $\frac{1}{2}$ to $1 \frac{1}{2}$ inches long; upper leaves alternate, lower ones opposite. Flowers solitary, small, yellow, borne reflexed in leaf axils. Very plentiful locally in saline soils.

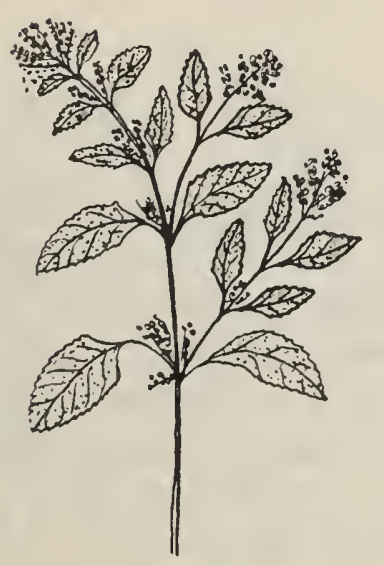

Iva xanthifolia Nutt.

FALSE RAGWEED

An erect, branched annual 2 to 6 feet high, with rough, downy stem. Leaves broadly ovate, rough above and downy below, long-stalked, 2 to 6 inches long. Flowers in terminal and axillary spike-like panicles. Very common in waste places around towns, spreading rapidly. 


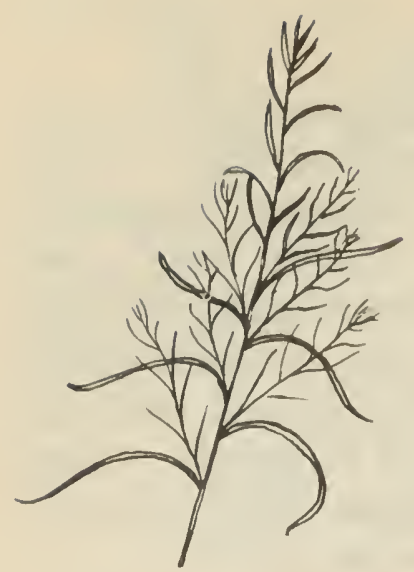

Kochia scoparia (L.) Schrad.

SUMMER-CYPRESS

An annual to 2 feet high, of ovoid or pyramidal shape. Leaves closely compacted, linear, pale-green when young, turning purplishred when mature. Seeds many, germinating readily to form a mass of matted seedlings the following year. Because of its fall coloring, it is often used as an ornamental in gardens, but has become a prolific weed.

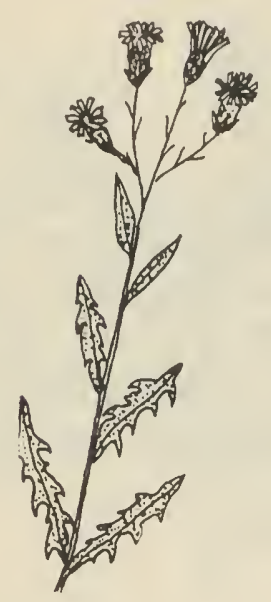

Lactuca pulchella (Pursh) DC.

BLUE LETTUCE

A pale bluish-green, smooth, hairless perennial 1 to 3 feet high, with white running rootstocks. Leaves usually linear-lanceolate, often with backward-pointing lobes. Heads bright blue, 1 inch across, in panicles. Seed bearing a short, thick beak and a tuft of white hairs. Common on cultivated lands and along roadsides.

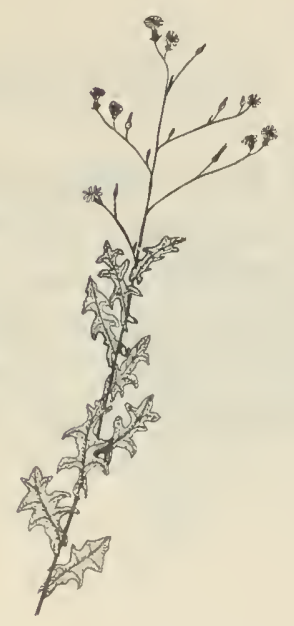

Lactuca scariola L.

LOBED PRICKLY LETTUCE

An erect annual, winter annual or biennial 1 to 5 feet high. Leaves 2 to 8 inches long, deeply lobed, the upper ones clasping the stem, underside of midvein bearing a row of short, stiff prickles. Flowers yellow, $\frac{1}{4}$ to $\frac{1}{3}$ inch across, numerous, in large open panicles. Seeds with long beak and a tuft of white hairs. Introduced, a common weed over area.

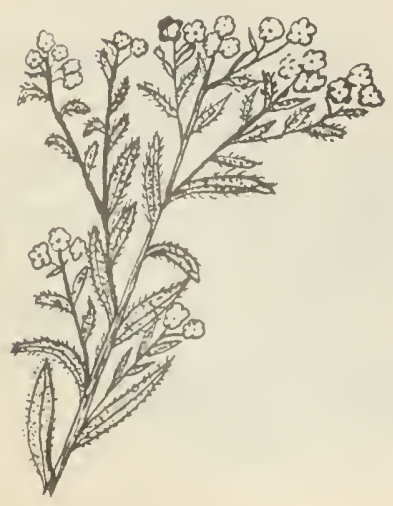

Lappula echinata Gilib.

BLUEBUR

A hairy annual or biennial, much branched, 6 inches to 2 feet high. Leaves 1 to 3 inches long, the lower ones stalked. Flowers in erect, bracted racemes, pale-blue, $\frac{1}{8}$ inch across. Fruit of 4 nutlets with two rows of hooked prickles around margins. Plant has an odor like a mouse-infested building. Introduced, but now very common and widespread. 


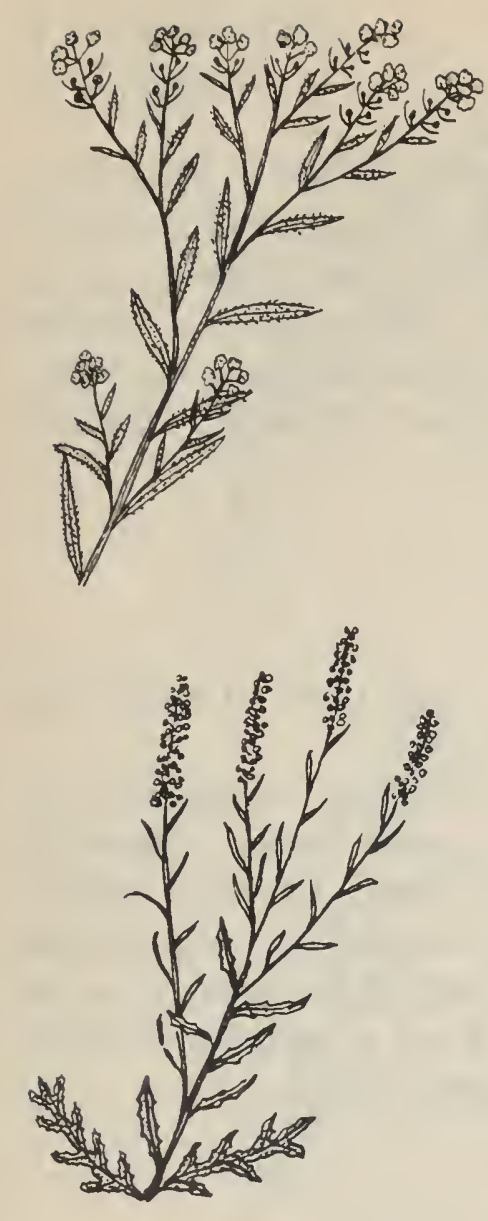

Lappula redowiskii (Hornem.) Greene

A native hairy annual 4 to 18 inches high. Leaves spatulate to linear-oblong, $\frac{3}{4}$ to $1 \frac{1}{2}$ inches long. Flowers pale-blue or white, usually less than $\frac{1}{8}$ inch across and in leafy-bracted racemes. Fruit of 4 nutlets with a single marginal row of hooked prickles. Fairly common on light dry soils throughout the southwest.

Lepidium densiflorum Schrad.

COMMON

PEPPER-GRASS

An annual or winter annual with erect stem branching toward top, 6 to 24 inches high. Stem leaves lanceolate, with a few coarse teeth; basal leaves often deeply cut and divided. Flowers small, usually without petals. Pods numerous, $\frac{1}{10}$ inch wide, with short stalks, heart-shaped, with a notch at top, a single seed in each section. Common in fields, waste places, and roadsides.

\section{Lepidium perfoliatum L.}

PERFOLIATE

PEPPER-GRASS

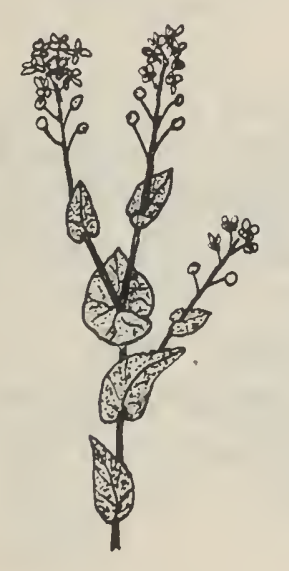

An annual with a much-branched stem 8 to 18 inches high. Lower leaves pale-green, finely dissected and divided; higher leaves becoming more entire, and upper ones entire with a pointed end and a cordate to entirely clasping base. Flowers small, yellow, in terminal racemes. Seed pods $\frac{1}{8}$ inch long, oval, one seed in each compartment. While actively growing, plants have a red tinge to the leaves. Introduced from Western States, as yet quite rare, but has been found near Swift Current.

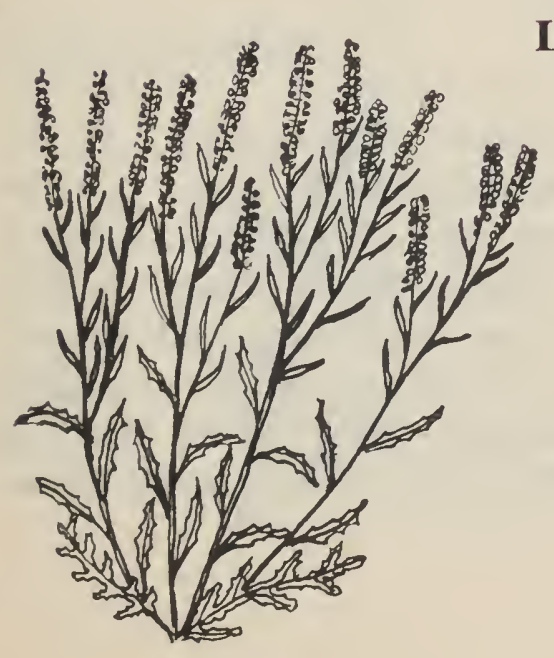

Lepidium ramosissimum $\mathrm{A}$. Nels.

BRANCHED PEPPER-GRASS

An annual or biennial $\frac{1}{2}$ to 2 feet high, branched from base. Stem leaves lanceolate with a few coarse teeth; basal leaves often deeply incised and divided. Flowers small with white petals shorter than the sepals. Seed pods somewhat pointed and notched at apex. Probably quite common, often confused with $L$. densiflorum. 


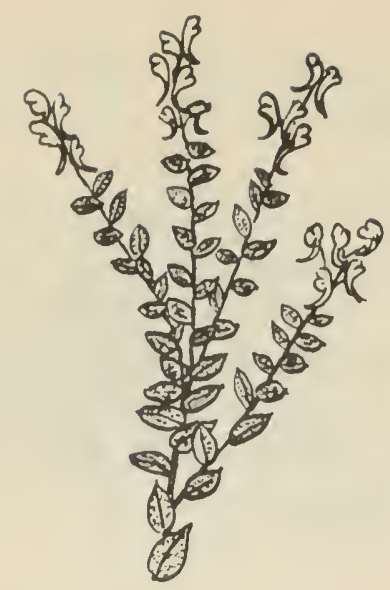

Linaria dalmatica (L.) Miller

An introduced perennial, coarsely branched, to $2 \frac{1}{2}$ feet high. Leaves many, $\frac{1}{2}$ to 2 inches long, ovate to lanceolate, often clasping stem. Flowers in a spike-like raceme, 1 to 2 inches long, with long spurs, bright-yellow, sometimes with orange-colored throat entrance. Escape from garden.

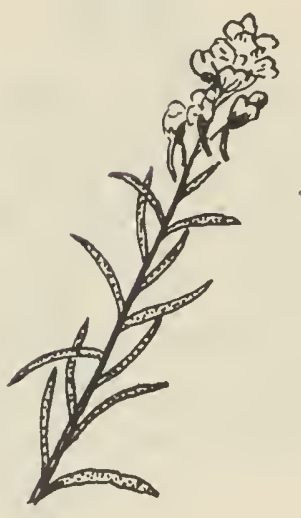

Linaria vulgaris Miller

YELLOW TOAD-FLAX

A perennial from creeping rootstocks, 8 inches to 2 feet high. Leaves linear, alternate, stalkless, $\frac{3}{4}$ to 3 inches long. Flowers brightyellow, with an orange throat and a long spur at the base, in dense terminal racemes, 1 to $1 \frac{1}{4}$ inches long. Introduced as a perennial snapdragon, it is now a persistent weed.

\section{Lupinus argenteus Pursh}

SILVERY LUPINE

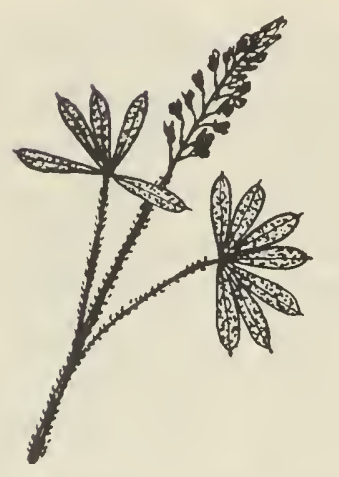

A shrubby, much-branched plant 1 to 2 feet high, with oppressed, silky-haired stems. Leaves alternate, with 6 to 9 narrowly oblanceolate leaflets $\frac{3}{4}$ to 2 inches long, sometimes silvery hairy, sometimes smooth above. Flowers lightviolet or purplish to almost. white, in long terminal racemes. Pods densely silky hairy, $\frac{3}{4}$ to 1 inch long, with 1 to 5 seeds. Plentiful in Foothills and Cypress Hills.

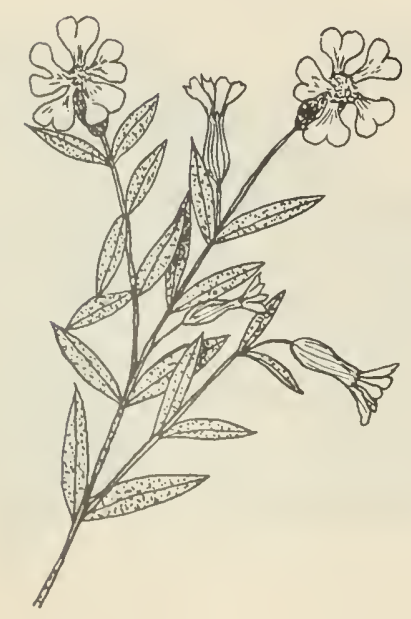

Lychnis alba Miller

WHITE COCKLE

A biennial or short-lived perennial 1 to $2 \frac{1}{2}$ feet high, much-branched with many stickyhaired stems. Leaves opposite, ovate-oblong, 1 to 3 inches long. Flowers white, 1 inch across, with male flowers on one plant and female flowers on another. Fruiting capsule enlarging and swelling at maturity, bearing 10 teeth at top. Becoming quite common in western parts. 
Lygodesmia juncea (Pursh) D. Don SKELETONWEED

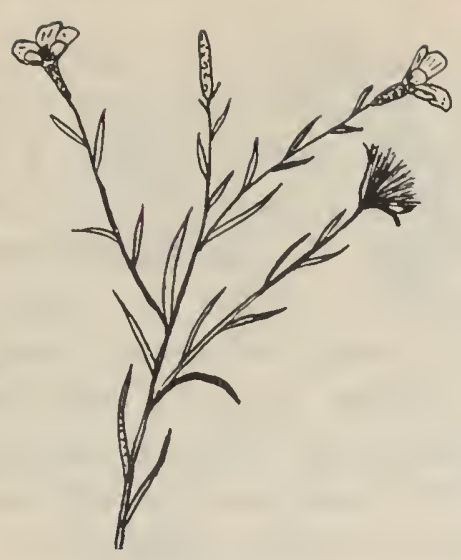

A much-branched, skeleton-like perennial 6 to 18 inches high, from tough, deep, sticky rootstock. Lower leaves linear-lanceolate, to $1 \frac{1}{2}$ inches long; upper leaves smaller or reduced to scales. Flower heads of 3 to 5 florets, borne singly at branch ends, pink, $\frac{1}{2}$ to $\frac{3}{4}$ inch across. Seeds short, without a beak, bearing a tuft of brownish hair, often with round insect galls easily mistaken for fruit. Common on light sandy soils.

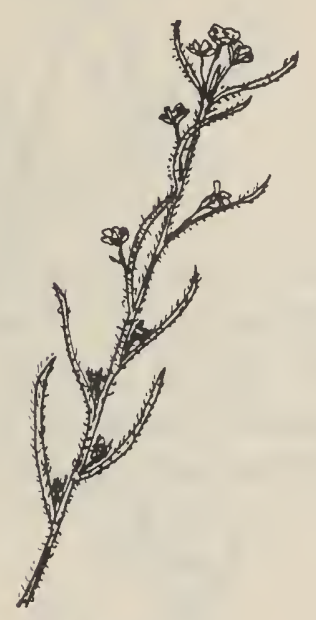

Madia glomerata Hook.

TARWEED

A strong, sticky, scented annual 8 to 20 inches high, with glandular hairy stem and leaves. Leaves alternate, linear, entire, 1 to 3 inches long. Flower heads in terminal and axillary crowded clusters. Heads $\frac{1}{4}$ inch high and $\frac{1}{8}$ inch wide with 1 to 5 small, yellow ray florets, often none, usually hidden in the glandular-hairy, sticky bracts. Sometimes found in slough margins or in moist open spots in woodlands.

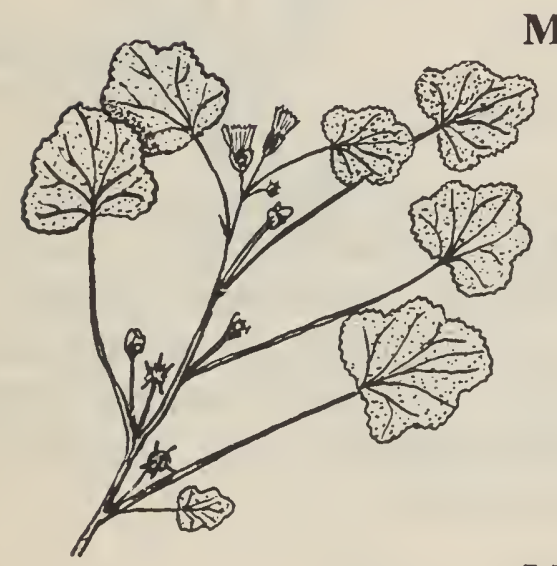

ROUND-LEAVED MALLOW

Malva rotundifolia $\mathrm{L}$.

A branched, prostrate annual or biennial. Leaves $\frac{3}{4}$ to $2 \frac{1}{2}$ inches across, roughly kidneyshaped and wavy-margined. Flowers pale-lilac, $\frac{3}{8}$ inch across, sepals as long as petals. Fruit a series of small capsules in a circle. Introduced, becoming very common on roadsides and waste lands.

Malvastrum coccineum (Pursh) A. Gray SCARLET MALLOW

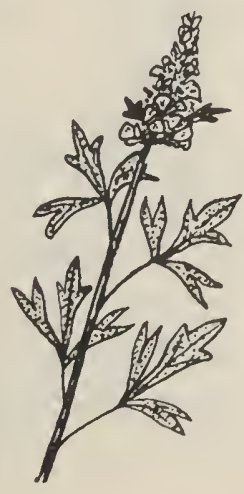

A native perennial with running rootstocks and woody base, in patches, 4 to 10 inches in height. Leaves usually round in outline but divided to base into wedge-shaped, lobed and cleft leaflets, with fine, white, star-shaped hairs giving a grayish appearance to plant. Flowers brick red, $\frac{1}{2}$ to $\frac{1}{3}$ inch across, in dense, short raceme-like clusters. Common on dry prairie in lighter soil zones in southern portions. 


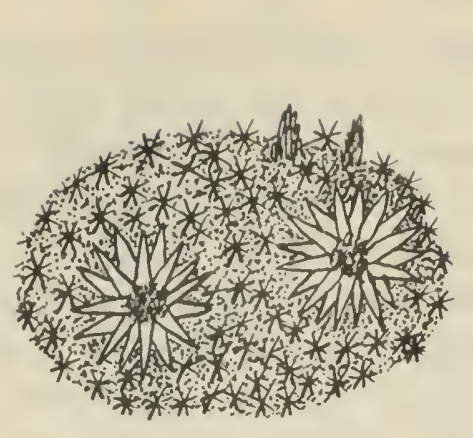

A pincushion-like cactus 1 to 3 inches high, 1 to 8 inches across, covered with cone-shaped tubercles each bearing a cluster of 3 to 8 reddish-brown spines $\frac{1}{2}$ to $\frac{3}{4}$ inch long. Flowers borne between tubercles, $1 \frac{1}{2}$ to 2 inches across, with numerous narrow, purple or dark-red petals, with a yellow center of many stamens. Fruit a pale-green, fleshy berry, $\frac{1}{2}$ inch long, which turns brown with age. Berries sweet and edible when ripe. Very common on open prairie and hillsides throughout southern prairies.

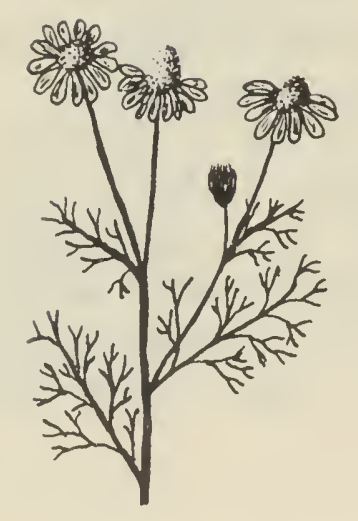

Matricaria chamomilla L.

A branching annual $\frac{1}{2}$ to 2 feet high, with finely divided leaves. Flower heads $\frac{3}{4}$ inch across with white ray florets and a conical disk of yellow florets. Plant smells faintly of pineapple. Introduced, reported from several locations.

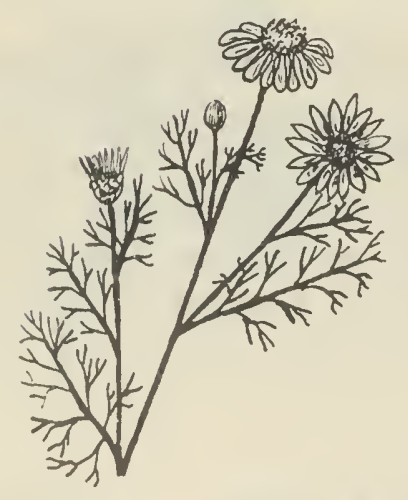

Matricaria maritima L.

var. agrestis (Knaf) Wilmott

SCENTLESS

CHAMOMILE

A much-branched annual with hairless stem, 8 to 30 inches high. Leaves stalkless, several times divided into narrow, thread-like segments. Flower heads at ends of branches, numerous, $\frac{1}{2}$ to 1 inch across, with yellow centers and white ray florets. Introduced, not common, waste places and roadsides.

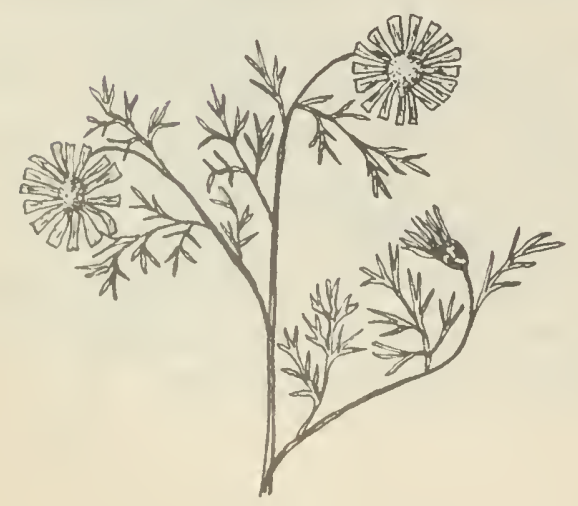

A hairless annual 3 to 18 inches high, with leaves several times divided into linear segments. Flower heads conical, $\frac{1}{4}$ inch across, with yellow center florets but no ray florets. Plants have a pineapple odor when squeezed. Introduced, very persistent in waste places, especially around farm driveways and yards. 


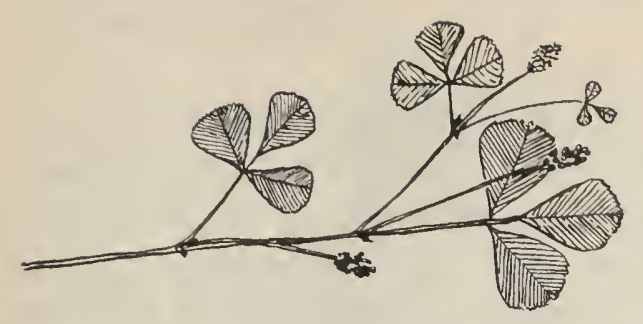

A prostrate, branched annual, 4 to 24 inches across. Leaves trifoliolate, obovate, toothed above the middle, $\frac{1}{8}$ to $\frac{1}{2}$ inch long. Flowers yellow, $\frac{1}{8}$ inch long, in short, head-like racemes less than $\frac{3}{8}$ inch long. Pods curved, small, black, with a single seed. Not common.

Medicago sativa L.

ALFALFA
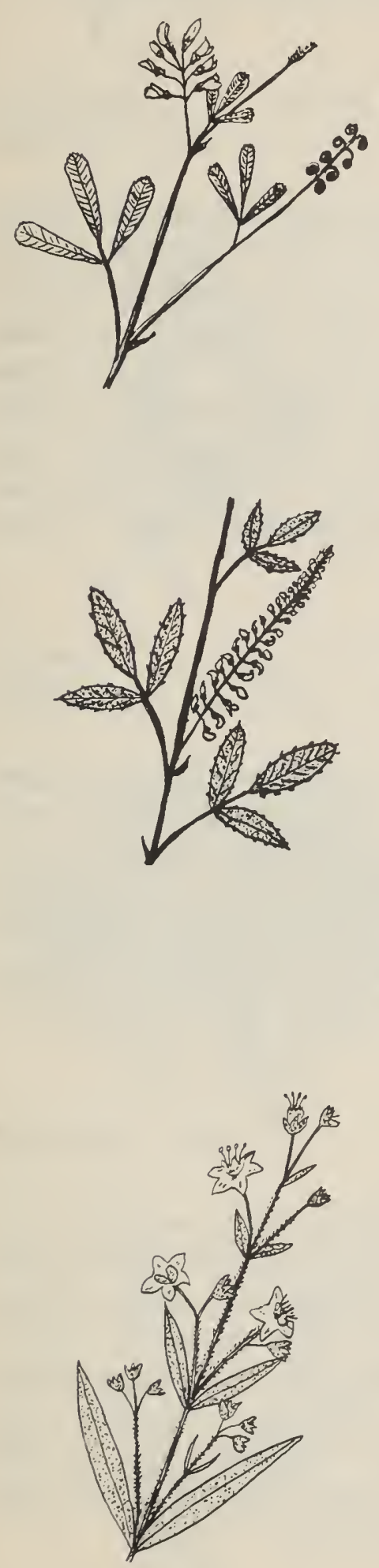

An erect perennial 1 to 3 feet high, much branched, with trifoliolate leaves. Leaflets obovate, sharply toothed toward apex, $\frac{3}{8}$ to $1 \frac{1}{4}$ inches long. Flowers purple, blue or mauve, in dense, oblong racemes. Pods hairy and twisted into 2 or 3 spiral turns. Common along roadsides and in waste places.

Melilotus alba Desr.

WHITE SWEET-CLOVER

An annual or biennial 2 to 6 feet high, with palmately or pinnately trifoliolate leaves. Leaflets $\frac{1}{2}$ to 1 inch long, toothed almost to base. Flowers white, $\frac{3}{16}$ inch long, in long, narrow, spike-like racemes. Standard slightly longer than wing petals. A yellow-flowered species, $M$. officinalis (L.) Lam., is similar except that the leaflets are somewhat narrower, the flowers yellow, and the standard and wing petals are of about equal length. Common along roadsides and waste places.

Mirabilis hirsuta (Pursh) MacM.

HAIRY

UMBRELLAWORT

A slender perennial 1 to 2 feet high, with sticky glandular hairs on the stem. Leaves 1 to 3 inches long, linear-lanceolate to lanceolate, hairy. Flowers without petals but sepals colored, forming a tube or bell, in clusters of 3 to 5 with a saucer-like bract beneath. A form of this species, sometimes classed as a separate species, Oxybaphus pilosus, has narrower leaves and the lower portions of the stem and leaves almost hairless except just under the nodes of the stem. Common on sandy soils throughout southern areas. 


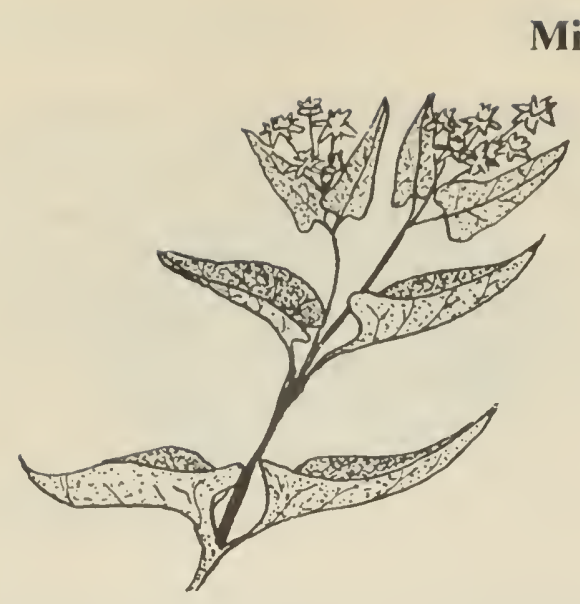

Mirabilis nyctaginea (Michx.) MacM. HEART-LEAVED UMBRELLAWORT

An erect perennial to 3 feet high, with an almost hairless stem swollen at the nodes. Leaves opposite, heart-shaped, 2 to 4 inches long, 1 to 3 inches wide. Flowers without petals but sepals deep reddish, united into a bell or funnel, in clusters of 3 to 5 with a saucer-like bract beneath. Quite common on rich soils in southeastern areas and spreading westward.

Moldavica parviflora (Nutt.) Britton

AMERICAN

DRAGONHEAD

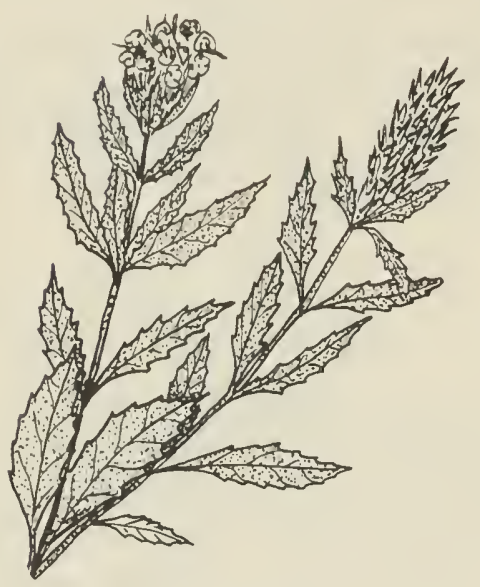

An erect, usually branched annual or biennial with a finely hairy stem, 1 to 2 feet high. Leaves lanceolate to oblong, 1 to 2 inches long, stalked, with large pointed teeth. Flowers in dense cluster 1 to 2 inches long and 1 to $1 \frac{1}{4}$ inches wide. Calyx stiff and spiny, giving a prickly stiffness to the clusters. Petals light-blue, only slightly longer than sepals. In woodland openings and old pastures, plentiful locally but not common.

Monolepis nuttalliana (R. \& S.) Greene

SPEAR-

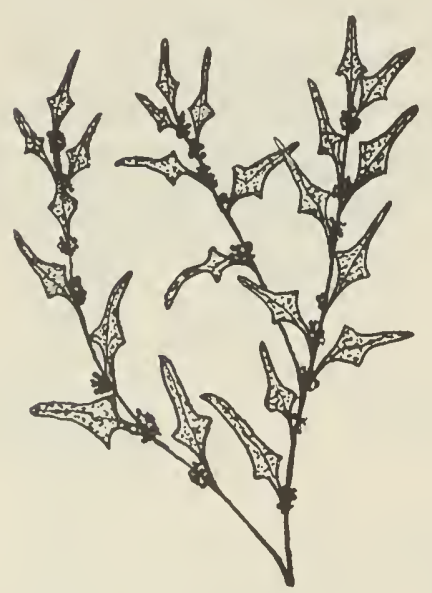

LEAVED GOOSEFOOT

A prostrate annual with fleshy reddish stems and hastate or spear-shaped leaves, which form a rosette in early stages. Plant spreading out over ground, often measuring 1 foot across. Flowers in small clusters in leaf axils. Germinating in early spring and flowering early. A weedy native, thriving in saline soils but also found on cultivated land.

Neslia paniculata (L.) Desv.

BALL MUSTARD

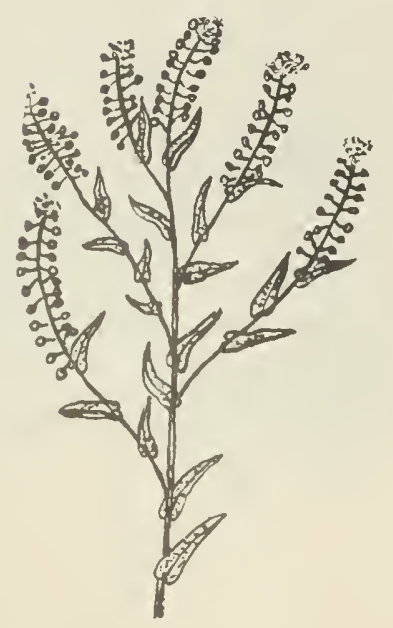

A tall, erect annual or winter annual 1 to 2 feet high, with branched stem. Plant yellowishgreen, with starry hairs. Lower leaves somewhat stalked, lanceolate; stem leaves arrowshaped, clasping stem. Flowers orange-yellow, small, $\frac{1}{8}$ inch across, clustered at the stem ends. Pods small, round, in long racemes, $\frac{1}{12}$ inch long, with one seed, remaining on plant when ripe. Introduced, widespread. 


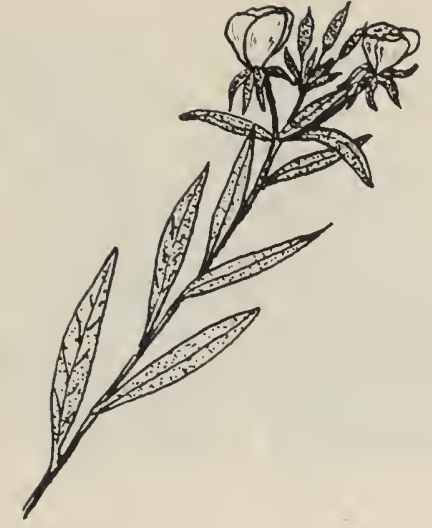

An erect biennial 1 to 6 feet high, from a taproot. Leaves lanceolate to ovate-lanceolate, 1 to 6 inches long, stalkless except for lower ones, which have short stalks. Flowers 1 to 2 inches across, yellow, opening in the evening, borne in a leafy, terminal spike. Capsules $\frac{3}{4}$ to $1 \frac{1}{4}$ inches long, finely hairy, opening at the top when ripe. Common in southeast as an introduced weed. Two varieties, canescens T. \& G. and hirsutissima Gray, are the more widespread western forms, on lighter soils.

Oenothera nuttallii Sweet

WHITE EVENINGPRIMROSE

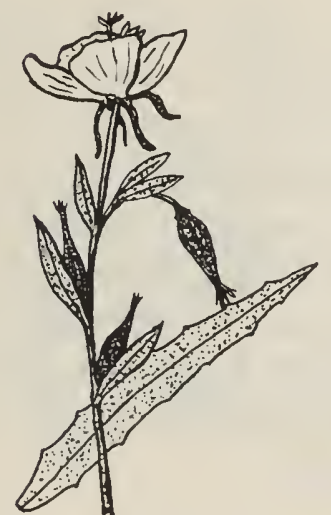

An erect, often much-branched perennial 1 to 3 feet high, from a white, fleshy rootstock. Stems shiny, white, with a shreddy bark. Leaves 1 to 4 inches long, pale-green, entire, linear, with wavy margins. Flowers $1 \frac{1}{2}$ inches across, in axils of upper leaves, white but fading to pink, opening in the morning, having an objectionable odor. Capsules 4-angled, narrow, curved, about 1 inch long. Common on roadsides in light soils and on sandy land in southern areas.

Opuntia polyacantha Haw.

PRICKLY-PEAR

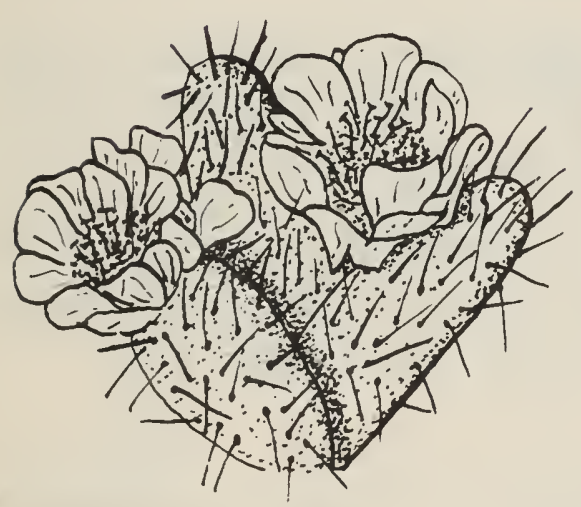

A prostrate, light-green cactus growing in large clumps. The internodes large and flattened, 2 to 4 inches long, with reddish-brown spines $\frac{1}{2}$ to 2 inches long. Flowers yellow to pinkish-orange, 2 to 3 inches across. Prickly berries 1 to $1 \frac{1}{4}$ inches long, with many seeds. The brittle prickly pear $O$. fragilis (Nutt.) Haw., has rounded red or reddish-green internodes. Common on dry prairies and light soils in drier areas of the southwest.

Oxytropis macounii (Greene) Rydb. EARLY YELLOW LOCOWEED

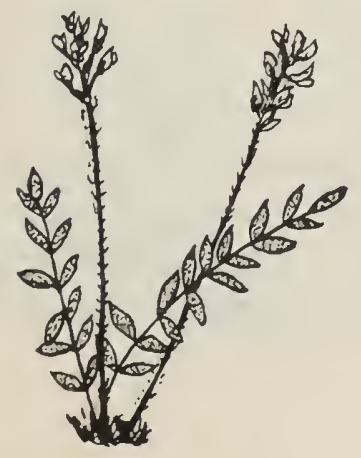

A low-growing, early-flowering plant with silky or short-haired leaves of 7 to 21 oval leaflets $\frac{1}{2}$ to 1 inch long. Flowers yellow, $\frac{5}{8}$ to $\frac{3}{4}$ inch long, often blooming in May. Pods oblong, $\frac{3}{4}$ inch long, short-haired, often with some black hairs amongst the white ones. Very dangerous to livestock. Common on dry hillsides and prairies of southwest. 


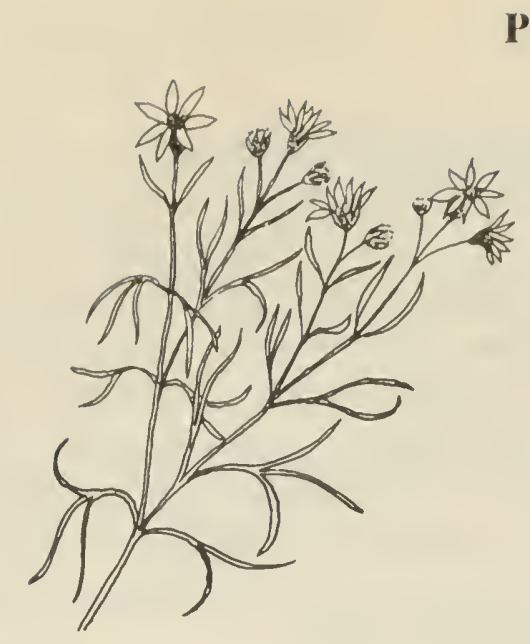

Picradeniopsis oppositifolia (Nutt.) Rydb.

PICRADENIOPSIS

Plantago major L.

COMMON PLANTAIN

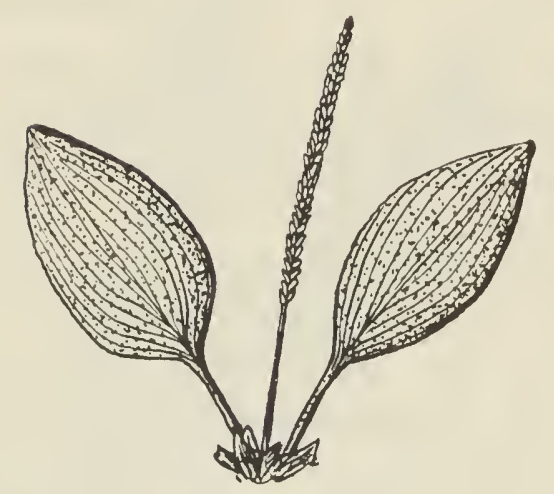

A perennial from a short, thick rootstock. Leaves numerous, dark-green, oval to ovate, 1 to 10 inches long, with long stalks and pronounced ribs running lengthwise. Flowers in a dense, narrow spike, 3 to 12 inches long, on long stems. Common in lawns, farm yards, and waste places across prairies. A variety, asiatica (L.) Decne., with tapering leaf bases and more upright leaves, has been recorded in the extreme northern parts of the area.

Polygonum aviculare L.

DOORWEED

A low annual, sometimes spreading to 2 feet,

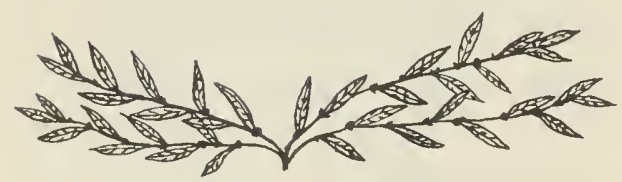
with alternate, broad, oblong, pale bluish-green leaves, $\frac{3}{4}$ to $2 \frac{1}{2}$ inches long. The ocrea or sheathing stipules silvery and translucent. Flowers small, in clusters in leaf axils. Seeds 3 -angled achenes. Common in waste places seeming to thrive with trampling.

Polygonum convolvulus L.

WILD BUCKWHEAT

An annual with a taproot and weak twining

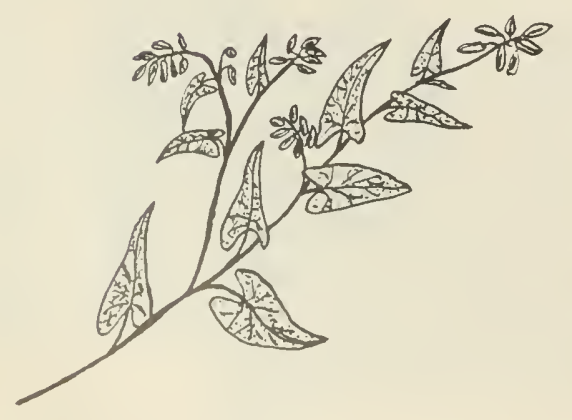
stems. Leaves alternate, arrow-shaped, palegreen, $\frac{1}{2}$ to 2 inches long, pointed at the tip, and with sheathing stipules called ocrea. Flowers small, without petals, greenish or pink, in small racemes in leaf axils or at ends of stems. Seed black, 3-angled, about $\frac{1}{8}$ inch long. Introduced from Europe but very common in cultivated land. 


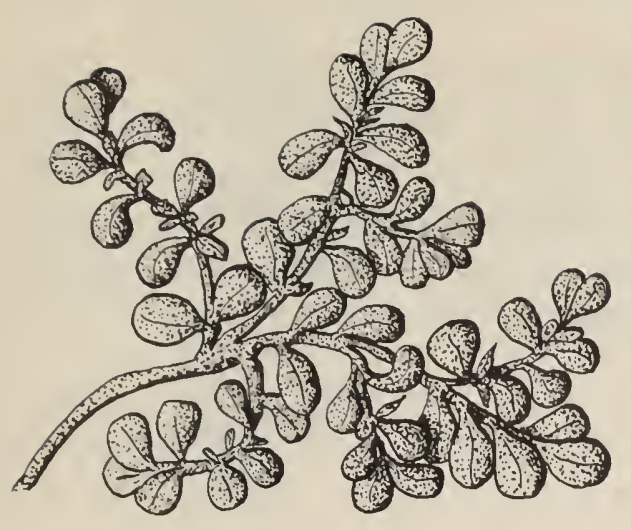

A succulent, prostrate annual, often forming mats up to $1 \frac{1}{2}$ feet across. Stems reddish, thick, fleshy, devoid of hairs. Leaves alternate, shiny dark-green, obovate or spatulate, thick, fleshy, $\frac{1}{4}$ to 1 inch long. Flowers single, stalkless, in leaf axils, bright yellow, $\frac{1}{4}$ inch across, with 2 sepals and 5 petals. Seeds numerous, tiny, produced in a pointed capsule or pyxis, the top of which breaks off when mature. Introduced, common in gardens everywhere.

\section{Potentilla anserina L.}

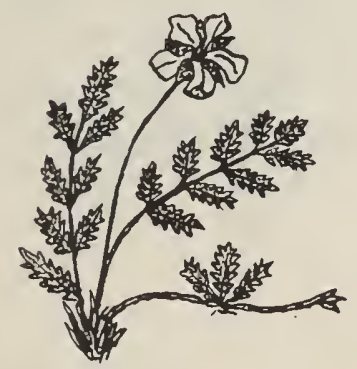

A low, spreading, tufted perennial with runners flat on the ground. Leaves pinnate, 3 to 18 inches long, with 7 to 25 leaflets, often with smaller leaflets in between, green above, whitewoolly beneath, a form of the species, $P$. anserina L. forma sericea (Hayne) Hayek, having leaflets that are silvery white on both sides. Flowers bright yellow, $\frac{3}{4}$ to 1 inch across, single, in long stalks, blooming the entire season. Common in wet places throughout area.

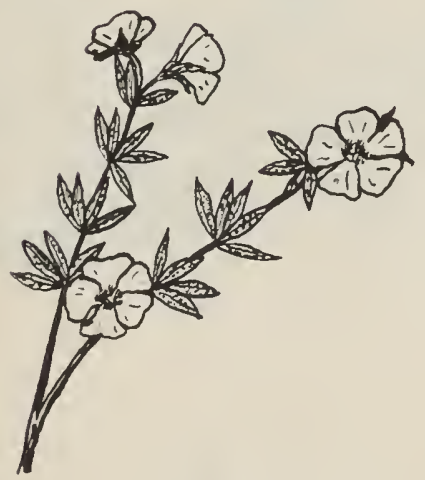

Potentilla fruticosa $\mathrm{L}$.

SHRUBBY CINQUEFOIL

A much-branched perennial shrub 1 to 4 feet high, from branching rootstocks. Leaves leathery, pinnate, with 5 to 7 leaflets $\frac{1}{2}$ to 1 inch long, linear-oblong, pointed at each end. Flowers yellow, $\frac{5}{8}$ to 1 inch across. Plentiful on low moist ground, especially on Cypress bench and in Foothills. Often used as a garden ornamental.

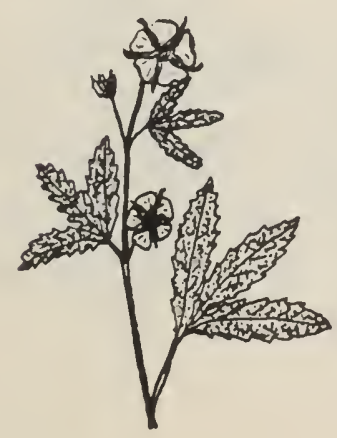

Potentilla norvegica L.

ROUGH CINQUEFOIL

A coarse, hairy annual or biennial with erect branches $\frac{1}{2}$ to 2 feet high. Leaves alternate with 3 coarsely toothed leaflets 1 to 4 inches long. Flowers numerous, yellow, sepals longer than the petals, in a dense cyme, $\frac{1}{4}$ to $\frac{1}{2}$ inch across. Common in moist areas and as a garden weed. 


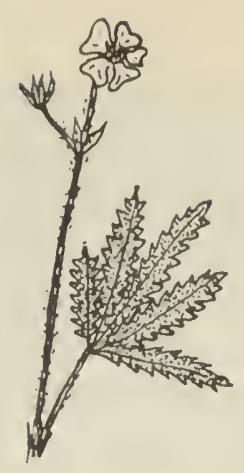

Potentilla recta $\mathrm{L}$.

An erect, leafy-stemmed perennial $\frac{1}{2}$ to 2 feet high, with hairy stems and leaf stalks. Leaves deeply toothed into 5 to 7 leaflets, somewhat hairy but paler underneath. Flowers pale-yellow or sulphur, $\frac{5}{8}$ to 1 inch across, on long stalks. Introduced, found throughout the area.

Ranunculus acris L.

TALL BUTTERCUP

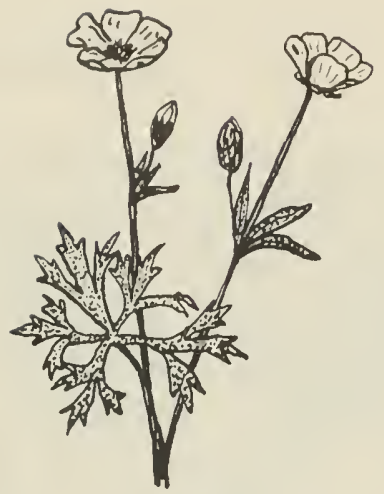

An erect perennial 1 to 3 feet high, branched above, with hairy stem. Basal leaves stalked, much cleft, divided. Flowers numerous, yellow, $\frac{3}{4}$ to 1 inch across, petals more than twice the length of the sepals. Introduced from Europe, sometimes found in moist areas. Very plentiful in some irrigated areas of southern Alberta.

Raphanus raphanistrum L.

WILD RADISH

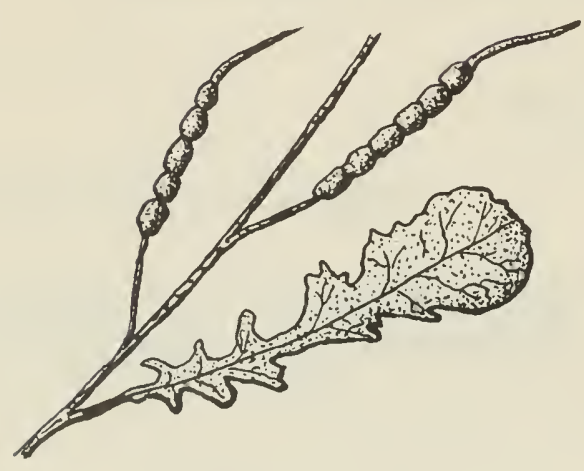

An erect annual or winter annual 1 to $2 \frac{1}{2}$ feet high. Lower and basal leaves deeply lobed with large terminal lobe, 4 to 8 inches long; upper leaves smaller. Flowers yellow with purplish veins, $\frac{1}{2}$ to $\frac{3}{4}$ inch across. Pods $1 \frac{1}{2}$ inches long, constricted between each seed and breaking easily into single-seeded sections. Introduced from Europe, becoming more common in eastern parts as a weed of waste places.

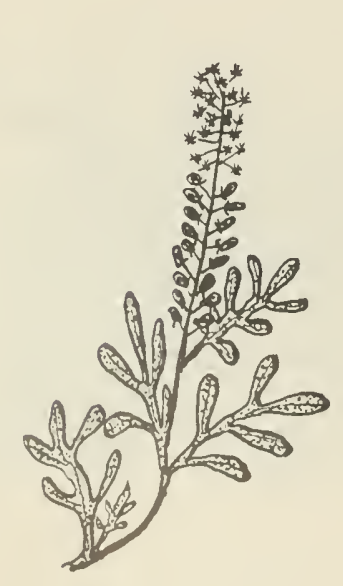

Reseda lutea L.

YELLOW CUT-LEAVED MIGNONETTE

A hairless perennial 8 to 20 inches high. Leaves alternate, deeply cut, with spatulate lobes and small glandular stipules. Flowers yellowish-green, in spike-like racemes. Seeds in small globose capsules. Introduced, sometimes found in imported grass seed. 


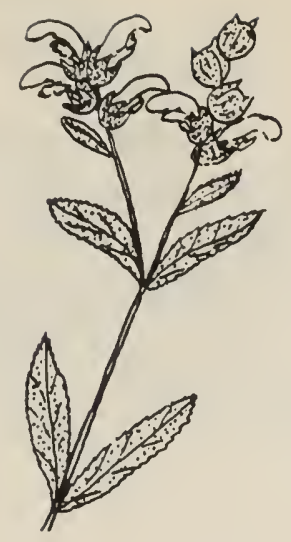

A branching annual 1 to 2 feet high. Leaves opposite, linear to lanceolate, 1 to 2 inches long, with finely toothed margins. Flowers $\frac{1}{4}$ to $\frac{1}{2}$ inch long, pale-yellow, with hairy, greenishyellow calyx, borne in upper leaf axils or in onesided leafy terminal spike. Calyx compressed, membranous, becoming inflated when ripe, then enclosing capsule. Not common but has been found in southern parts in moist places and open woodlands.

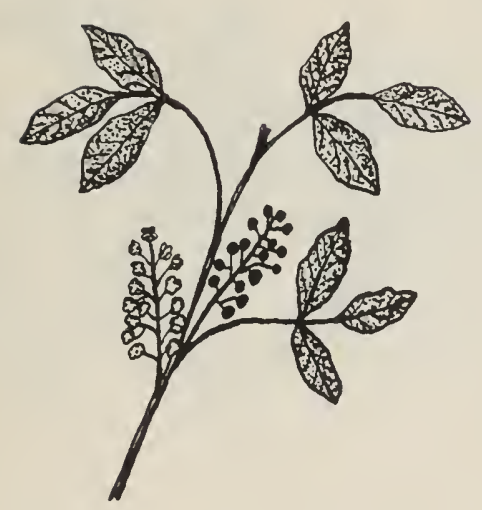

Rhus radicans $\mathrm{L}$.

POISON-IVY

var. rydbergii (Small) Rehder

A single stemmed, erect shrub 4 to 12 inches high, with woody stem and creeping rootstock. Leaves of 3 large, strongly veined, bright-green leaflets, $1 \frac{1}{4}$ to 4 inches long. Flowers whitishyellow, in dense panicles in leaf axils. Fruit dull whitish berry, about $\frac{1}{4}$ inch across. May cause severe skin irritation to humans. Found in shady woodlands and ravines.

\section{Rorippa austriaca (Crantz) Besser AUSTRIAN CRESS}

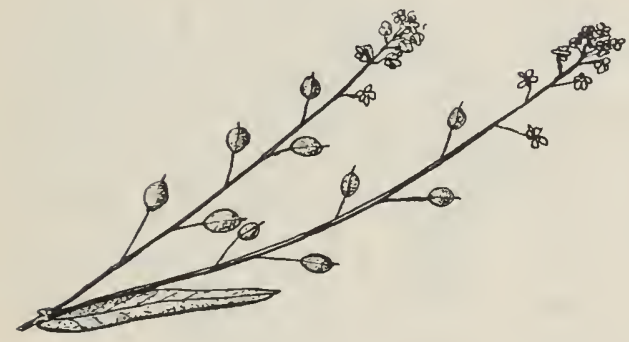

A perennial $1 \frac{1}{2}$ to 3 feet high, with running roots and smooth stem. Leaves alternate, almost entire or merely toothed but not dissected, the lower stalked, the upper stalkless. Flowers in racemes, small, yellow. Seeds small, almost round, $\frac{1}{8}$ inch long, on stalks $\frac{1}{4}$ to $\frac{1}{2}$ inch long. Introduced, rare, in grain fields.

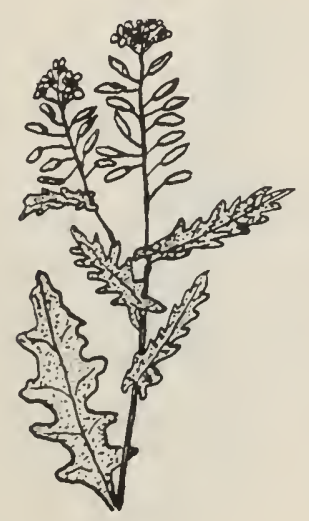

A native branching annual or biennial 1 to 4 feet high. Leaves deeply dissected, lower ones stalked, 3 to 7 inches long, the upper less dissected or lobed and without stalks. Flowers small, yellow, less than $\frac{1}{4}$ inch across. Pods linear or globose, with two rows of seeds in each compartment. Common in wet places over prairies. There are several varieties of this species. 


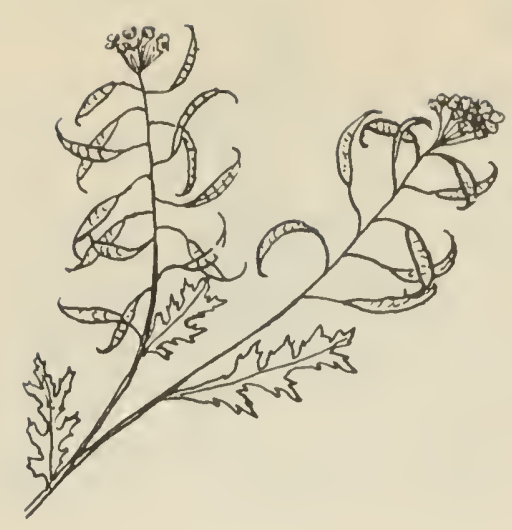

Rorippa sinuata (Nutt.) Hitchc.

SPREADING

YELLOW CRESS

A native perennial 4 to 18 inches high. Leaves cleft or divided, 2 to 3 inches long, lobes obtuse. Flowers yellow, $\frac{1}{16}$ inch across. Pods linear-oblong, $\frac{1}{3}$ to $\frac{1}{2}$ inch long. Although not common, found in several locations throughout the prairies.

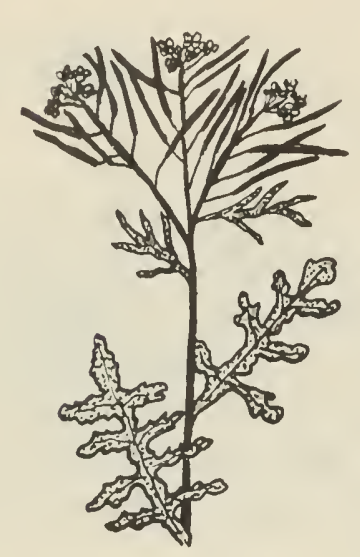

Rorippa sylvestris (L.) Besser

CREEPING
YELLOW CRESS

An introduced perennial with creeping roots, smooth stem, and pinnately divided leaves with sharp-toothed divisions. Flowers yellow, $\frac{1}{4}$ to $\frac{1}{3}$ inch across. Seed pods linear, $\frac{1}{3}$ to $\frac{1}{2}$ inch long on slender stalks, with a single row of seeds in each compartment. Found in a few isolated locations.

Rosa woodsii Lindl.

WOOD'S ROSE

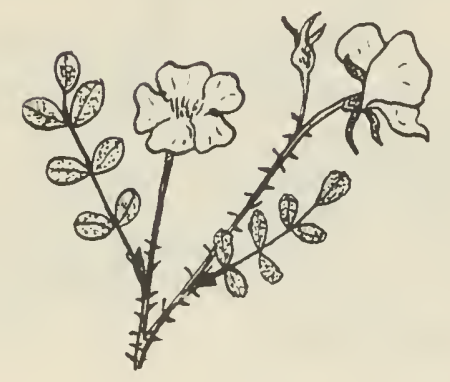

A perennial bush 1 to 6 feet high, with stems armed with straight or slightly curved prickles, which are often broad and flattened at the base. Leaves of 5 to 9 oval or obovate leaflets $\frac{1}{2}$ to $1 \frac{1}{2}$ inches long. Flowers pink, 1 to 2 inches across. Fruit a hip, with a constricted neck, about $\frac{3}{8}$ inch across. Common in bluffs, ravines, and sandhills across southern prairies.

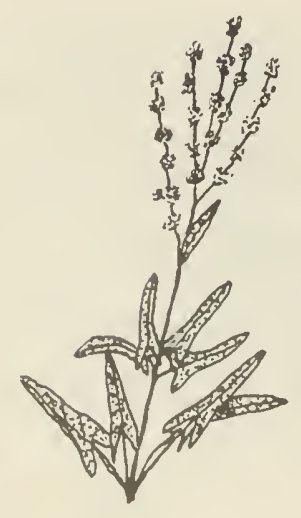

Rumex acetosella L.

SHEEP SORREL

A low-growing perennial usually less than 12 inches high, with leaves 1 to 4 inches long, narrowly hastate or spear-shaped. Sepals not enlarging in fruit. An introduced weed, only rarely found in the area, in dry or sandy places and on acid soils. 


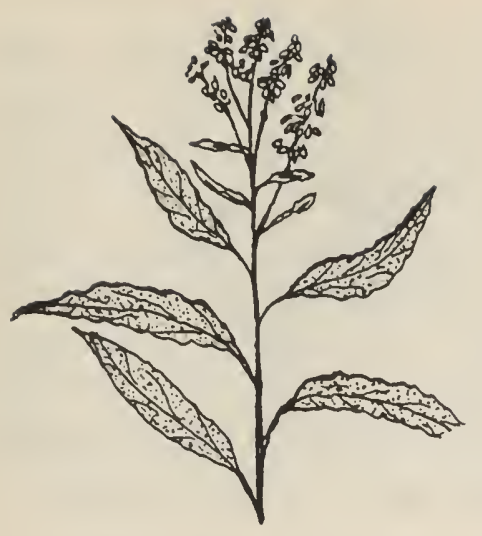

Rumex crispus L.

An introduced perennial over 3 feet high in favorable locations. Leaves alternate, simple, lanceolate, wavy-margined, 6 to 12 inches long, upper ones being smaller. Flowers in several crowded whorls in a raceme. No petals but 6 greenish sepals, the 3 inner being enlarged, heart-shaped, and each bearing a round plump grain or tubercle. Common throughout area in moist locations.

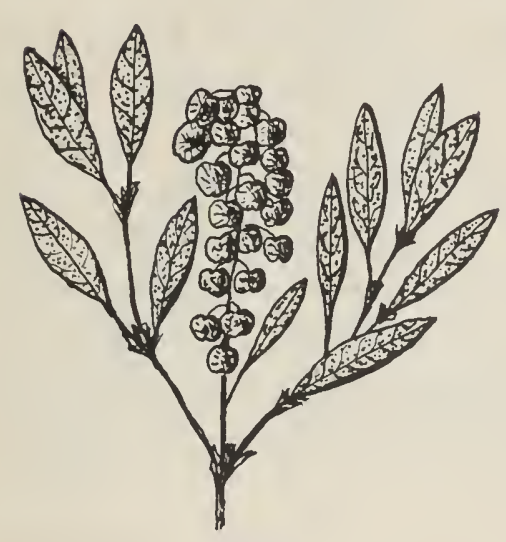

Rumex venosus Pursh

SAND DOCK

A perennial with running, woody rootstocks and branched stems. Sheathing stipules or ocrea whitish and papery, very noticeable. Leaves pale-green, 2 to 5 inches long and nearly half as wide. Calyx valves in fruit very conspicuous, almost $1 \frac{1}{2}$ inches broad, bright red to pink. Found on sandy soils throughout the southwest.

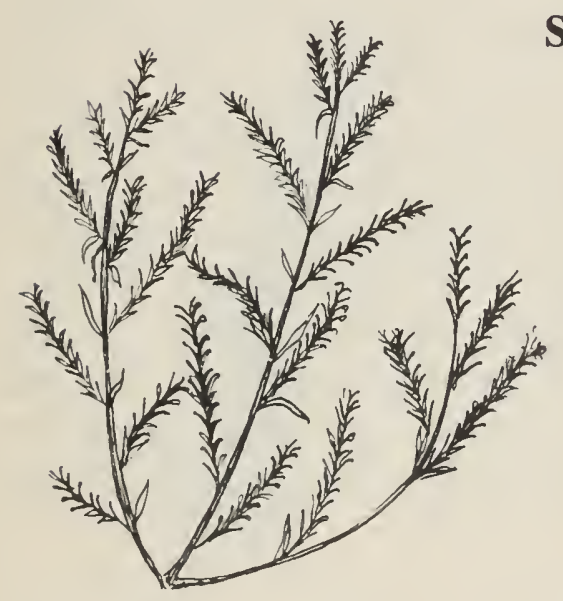

Salsola pestifer A. Nels.

RUSSIAN-THISTLE

An introduced annual 1 to 2 feet high. Early leaves 1 inch long, dark-green, and thread-like; later leaves shorter and broader, narrowing to a hard, sharp point. Flowers in axils of upper leaves. Seed with membranous wings. Plants usually turning reddish at maturity, breaking off and rolling with the wind. Very common across prairies.

\section{Salvia sylvestris L.}

WOOD SAGE

A coarse, densely downy perennial 1 to $2 \frac{1}{2}$ feet high. Leaves $\frac{1}{2}$ to 4 inches long, oblong to ovate-lanceolate; lower leaves stalked, upper ones stalkless. Flowers in long, narrow, terminal spikes 2 to 6 inches long and $\frac{1}{2}$ to $\frac{3}{4}$ inch thick. Flowers deep violet-blue, petals to $\frac{1}{2}$ inch long. Found in scattered locations. 
A smooth, hairless annual 1 to $2 \frac{1}{2}$ feet high. Leaves grayish-green, smooth, entire, clasping stem, opposite, 1 to 3 inches long, ovate-lanceolate. Flowers in loose corymbose cymes at head of stem. Petals united, $\frac{1}{2}$ inch long with 5 palepink petals forming a flat corolla $\frac{1}{2}$ inch across. Fruit an ovoid capsule with round, dull-black seeds, $\frac{1}{12}$ inch in diameter. Common in fields and roadsides in southern areas. Often included in wild flower packages sold by seed houses.

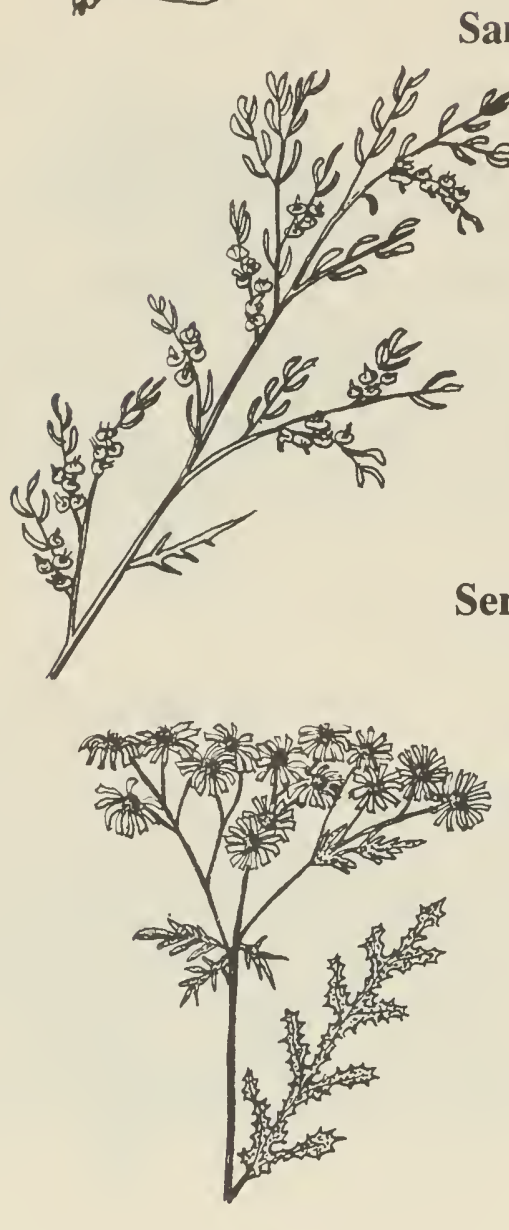

Sarcobatus vermiculatus (Hook.) Torr. GREASEWOOD

A much-branched perennial 5 to 6 feet high, with spiny branches. Stems nearly white, leaves pale yellowish-green, linear, and 1 to $1 \frac{1}{2}$ inches long. Male flowers in cylindrical spikes at ends of branches, female flowers singly in leaf axils. Fruit surrounded by a broad membranous wing. Rather poisonous to livestock, especially to lambs in spring. Strongly alkali-tolerant, found in saline sloughs and flats in southwestern areas.

Senecio jacobaea L.

TANSY RAGWORT

A perennial 2 to 3 feet high from shallow, short, thick rootstocks. Usually hairless but sometimes with tufts of woolly hairs at leaf axils. Leaves 2 to 3 times divided into broad, overlapping segments, dark green. Lower leaves 6 to 8 inches long, stalked; upper ones stalkless and slightly smaller. Flower heads showy, golden yellow, $\frac{3}{4}$ inch across, in large, dense, terminal clusters. Common in eastern Canada and at one time thought to have spread to western areas, but as yet, presence here not certain.

Senecio palustris (L.) Hook.

MARSH RAGWORT

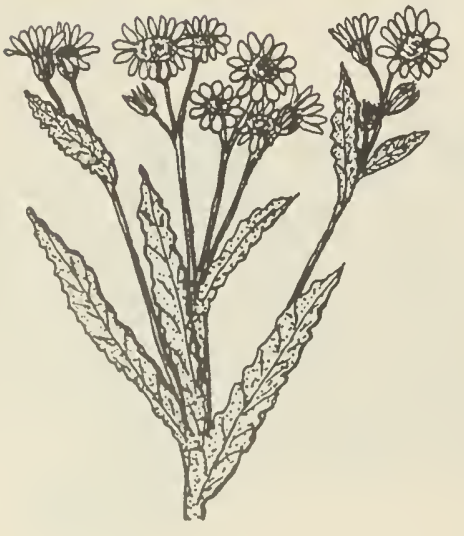

A coarse, hollow-stemmed annual 6 to 24 inches high, with fleshy stems which, although slightly cobwebby when young, are quite hairless when mature. Lower leaves lanceolate to spatulate, 2 to 6 inches long, with wavy margins and winged stalks; upper leaves smaller, stalkless, somewhat lobed or dentate, linear-lanceolate, and clasping the stem. Flower heads in crowded, dense, terminal clusters, pale-yellow, $\frac{1}{2}$ to $\frac{3}{4}$ inch across. Common around sloughs, stream banks, and lake shores. 

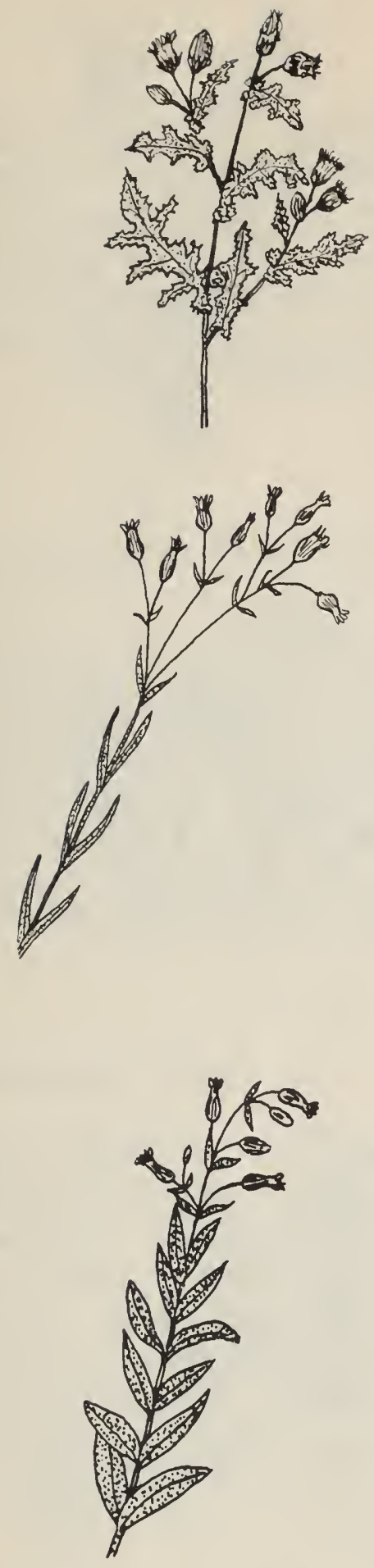

A hollow-stemmed, much-branched annual 6 to 15 inches high. Leaves 2 to 6 inches long, lobed, lower ones stalked, upper ones clasping the stem. Flower heads in clusters at ends of branches, without ray florets, each $\frac{1}{4}$ inch across, often with some black-tipped bracts. Not common, found in gardens and fields across prairies.

Silene antirrhina $\mathrm{L}$.

SLEEPY CATCHFLY

An annual 18 to 20 inches high, with erect branches. Stem usually sticky near nodes and sometimes slightly hairy. Leaves 1 to 2 inches long, lanceolate. Flowers very small, $\frac{3}{16}$ inch across, pink. Not common, found in eastern parts of area.

Silene cserei Baumgarten

SMOOTH CATCHFLY

A biennial 4 to 36 inches high, with opposite leaves and resembling bladder campion except for having a taproot. Leaves smooth, thick, elliptic-lanceolate, 2 to 4 inches long. Flowers numerous, pink, with an inflated calyx, white petals cleft at the tip and in whorls around ștem. Mature calyx ovoid and $\frac{1}{2}$ inch long. Increasing along railway grades throughout the area.

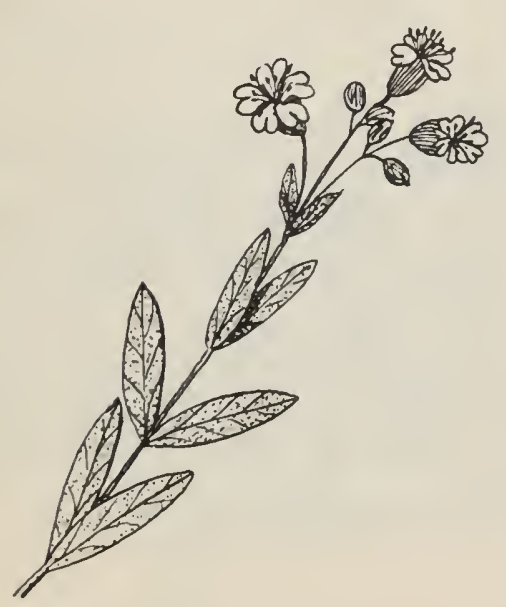

Silene cucubalus Wibel

BLADDER CAMPION

A tall, erect perennial 6 to 24 inches high, with smooth hairless stems. Leaves opposite, lanceolate and smooth, 1 to 3 inches long. Flowers $\frac{1}{2}$ to $\frac{3}{4}$ inch across, in loose open panicles. Sepals united in a bladder $\frac{3}{8}$ to $\frac{1}{2}$ inch long. Petals 2-cleft, white. Introduced, persistent, not common but generally plentiful where found. 


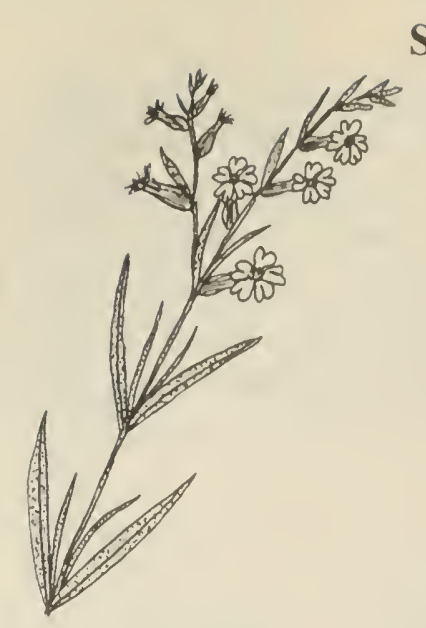

Silene dichotoma Ehrh.

A sticky-haired biennial 1 to 2 feet high. Leaves lanceolate to oblanceolate, 2 to 3 inches long, lower ones stalked and hairy, upper without stalks. Petals deeply cleft, white. Flowers stalkless or with very short stalks, in a spikelike raceme. Introduced, as yet quite rare, but capable of becoming troublesome.

Silene noctiflora L. NIGHT-FLOWERING CATCHFLY

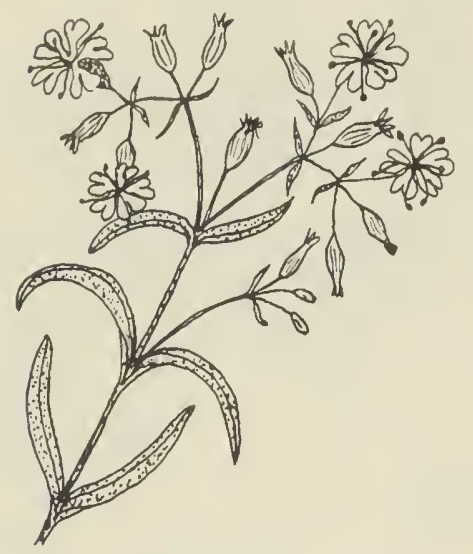

An erect, hairy, sticky annual 1 to 3 feet high. Leaves hairy, sticky, basal ones oblanceolate, 2 to 5 inches long with short stalks, upper lanceolate, 1 to 3 inches in length and stalkless. Sepals united in a tube $\frac{1}{2}$ inch long with lightand dark-green upright stripes. Petals white, deeply cleft, opening only at night. An introduced weed becoming plentiful throughout southern areas.

Sinapis arvensis $\mathrm{L}$.

WILD MUSTARD

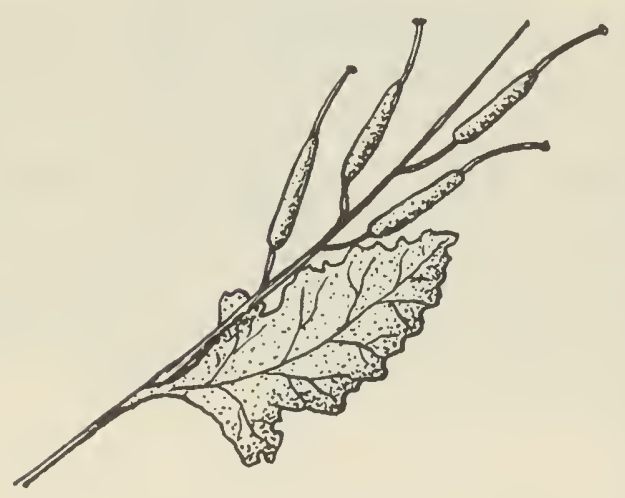

An introduced annual, 1 to 2 feet high, with scattered stiff hairs. Lower leaves 4 to 6 inches long, stalked, deeply lobed; upper stalkless, less divided, often entire. Flowers yellow, $\frac{2}{3}$ inch across. Pods linear, rough, $\frac{1}{2}$ to $\frac{3}{4}$ inch long, with slight constructions between seeds and with a flattened beak which sometimes contains a seed. Common throughout area in grain fields and waste places, especially moister sites and on heavy clay.

Sisymbrium altissimum L.

TUMBLING MUSTARD

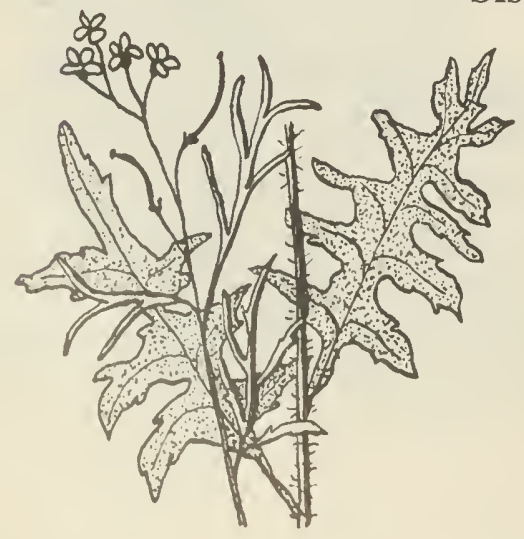

An introduced annual or winter annual 1 to 4 feet high. Basal leaves forming a rosette of pale-green, soft-hairy, divided leaves; stem leaves varying in shape from entire to pinnate or lobed. Flowers pale yellow, $\frac{1}{3}$ inch across. Pods thin, 2 to 4 inches long, each containing over 100 small, light-brown seeds. Plant breaks off at maturity and is carried by the wind. Common on cultivated and range land. 
An introduced, branched annual 4 to 5 feet high. Upper portion of plant smooth, lower parts with downward-pointing hairs. Leaves deeply lobed, upper ones with lanceolate divisions. Flowers bright yellow. Pods linear, $1 \frac{1}{4}$ inches long. Rare, found in southern regions.

Sium suave Walt.

WATER PARSNIP

A tall, marshland perennial 2 to 6 feet high,

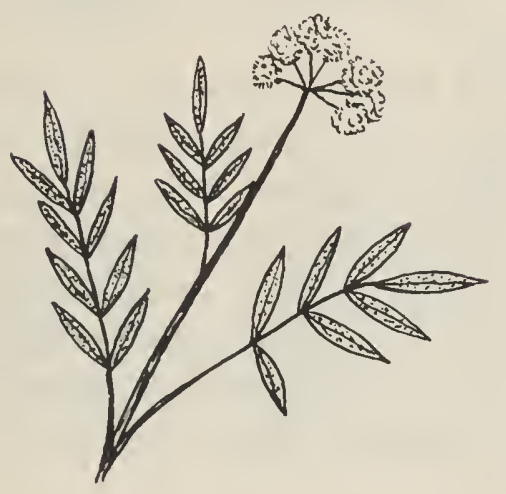
with smooth hollow stems and stout rootstocks. Early underwater leaves 2 to 3 times pinnately divided into thread-like leaflets; later leaves growing above water, singly pinnate with linear or narrowly lanceolate, sharply toothed leaflets $1 \frac{1}{2}$ to 4 inches long. Flowers white, in compound umbels 2 to 3 inches across. Fruit $\frac{1}{8}$ inch long, ovate, flattened with prominent ribs. May have slightly poisonous properties, but by no means as dangerous as water hemlock, which it resembles. Common in sloughs and wet places.

Solanum dulcamara L.

BITTERSWEET

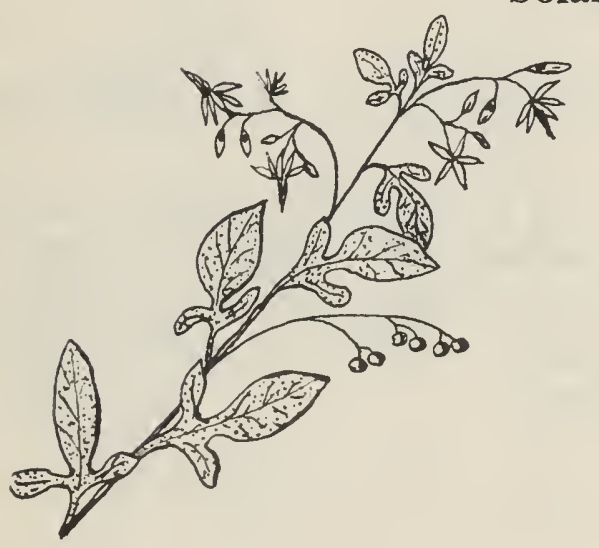

A woody-based perennial climbing or twining vine with branches several feet long. Leaves 2 to 4 inches long, upper ovate, cordate-based, pointed at apex, lower often 3-lobed with one large ovate middle lobe and two small basal lobes. Flowers in panicles or compound cymes, $\frac{1}{2}$ inch across, wheel-shaped, with purple petals and yellow anthers. Fruit round or oval red berry, $\frac{3}{8}$ inch long. A scarce, introduced species, very poisonous, found in all prairie provinces.

Solanum nigrum L.

BLACK NIGHTSHADE

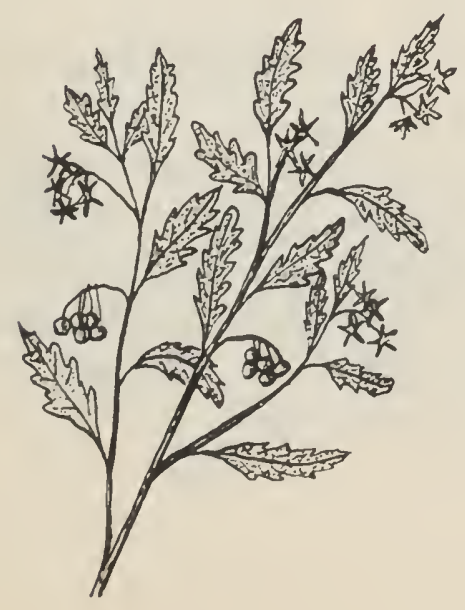

An erect annual 4 to 12 inches high, with entire-margined, ovate leaves 1 to 3 inches long. Flowers white, rotate, $\frac{1}{2}$ inch across, in clusters of 3 to 10. Fruit a green berry, turning black when ripe, $\frac{3}{8}$ inch across. There is some variation in hairiness and some authorities call the more hairy-stemmed forms $S$. interius Rydb. An introduced species, quite common in gardens and waste places. 


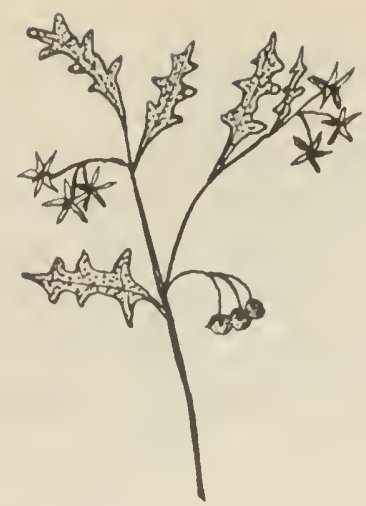

Solanum triflorum Nutt.

WILD TOMATO

A low annual, spreading in a mat 6 to 24 inches across. Leaves deeply lobed, 1 to 3 inches long, covered with scattered hairs. Flowers round, white, $\frac{1}{4}$ to $\frac{3}{8}$ inch across, usually in clusters of three. Fruit a smooth, green berry, $\frac{1}{2}$ inch in diameter. Berries, relished as preserves by some, may cause violent sickness when eaten by others. A native species on disturbed prairie.

Sonchus arvensis L.

PERENNIAL SOW-THISTLE

A perennial 1 to 5 feet high, with strongly creeping rootstocks. Stems usually hollow, not much branched. Lower leaves 4 to 10 inches long, narrowed to a short stalk and having backward-pointing lobes, upper without stalks and less lobed. Leaf teeth spine-tipped. Flowers bright yellow, in a corymbose panicle on bristly stalks. Common in moister areas of prairies.

Sonchus asper (L.) Hill

PRICKLY SOW-THISTLE

An annual 2 to 6 feet high. Leaves slightly lobed, clasping stem at base; lobes spine-tipped, basal lobes rounded. Flowers $\frac{1}{2}$ to 1 inch across, pale-yellow. Common in gardens and roadsides across the prairies.

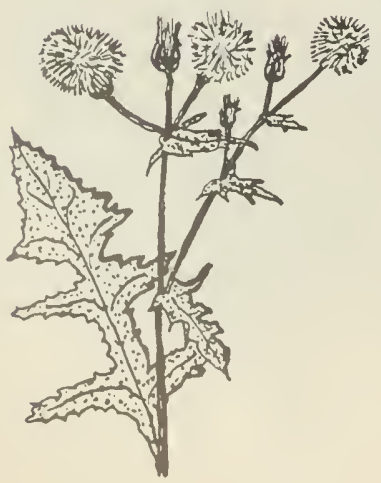

Sonchus oleraceus L.

ANNUAL SOW-THISTLE

An annual 2 to 8 feet high. Leaves deeply lobed, having soft prickles; lower leaves stalked, upper leaves clasping stem. Heads pale-yellow, $\frac{1}{2}$ to 1 inch across. Fairly common in eastern parts as a garden weed or a weed of waste places, scarcer to the west. 


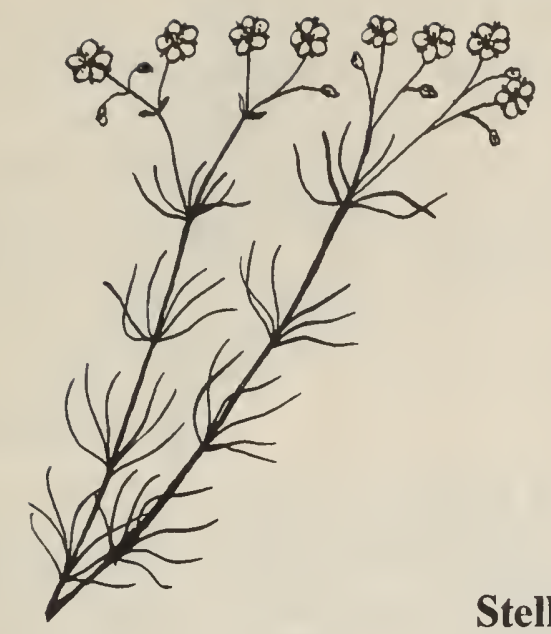

An introduced branching annual 6 to 18 inches high, with very narrow leaves 1 to $1 \frac{1}{2}$ inches long, in whorls around the stem. Flowers white, in branching cymes at ends of stems, $\frac{1}{4}$ inch across. Not common, in fields and roadsides in western portions of area.

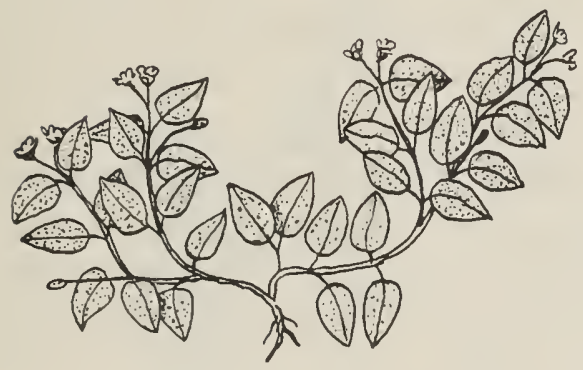

Stellaria media (L.) Cyrill. COMMON CHICKWEED

A prostrate annual with a line of fine white hairs on the reclining, trailing stems. Leaves broadly ovate, $\frac{1}{4}$ to 1 inch long, on short stalks. Flowers white, $\frac{1}{4}$ inch across, deeply cleft, the 5 petals easily mistaken for 10 separate petals. Introduced from Europe, common in lawns and gardens.

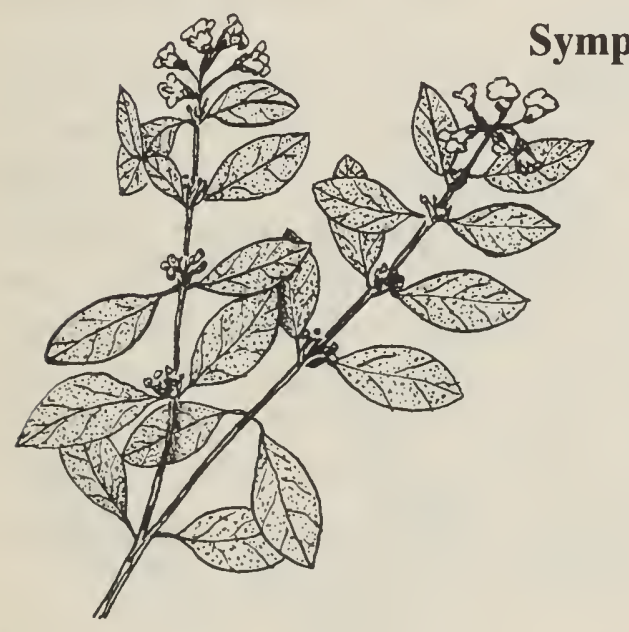

Symphoricarpos occidentalis Hook.

WESTERN SNOWBERRY

A perennial shrub 1 to 4 feet high, with creeping roots. Leaves almost round to oval or ovate, slightly soft-hairy beneath, 1 to 3 inches long. Flowers in dense spikes at branch ends and in leaf axils, pink and white, with styles and stamens projecting beyond the petals. Fruits waxy, snow-white berries. Common, in dense stands, on open prairie, coulees, and ravines.

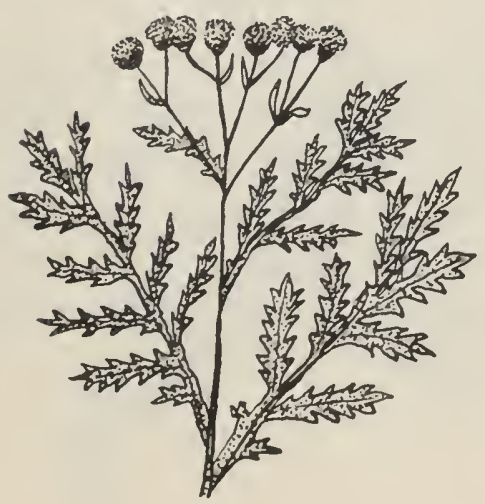

Tanacetum vulgare $\mathrm{L}$.

TANSY

A stout, erect-stemmed perennial 1 to 3 feet high. Leaves 2 to 10 inches long, pinnately divided into narrow, toothed segments, aromatic when bruised. Flower heads without ray florets, $\frac{1}{4}$ to $\frac{3}{8}$ inch across, in a flat-topped cluster. Introduced as a garden plant and becoming established in many localities. 


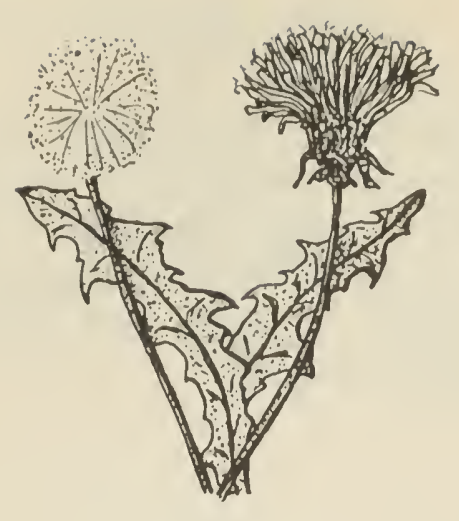

Thlaspi arvense $\mathrm{L}$.

An introduced annual or winter annual 1 to 18 inches high, with smooth leaves and hairless stems. Lower leaves oblanceolate, stalked, soon withering and falling off; stem leaves lanceolate to oblong, eared at base, clasping stem. Flowers small, white, $\frac{1}{8}$ inch across, in clusters at ends of stems. Pods oval, flat, broadly winged, $\frac{1}{3}$ to $\frac{1}{2}$ inch across, deeply notched at top, on stalks $\frac{1}{2}$ to $\frac{3}{4}$ inch long; pod clusters green at first, turning dull-yellow to orange at maturity. Seeds purplish chocolate brown, $\frac{1}{12}$ inch across, with a grooved pattern like a finger print on each side. Very common across prairies.

\section{Tragopogon dubius Scop. YELLOW GOAT'S-BEARD}

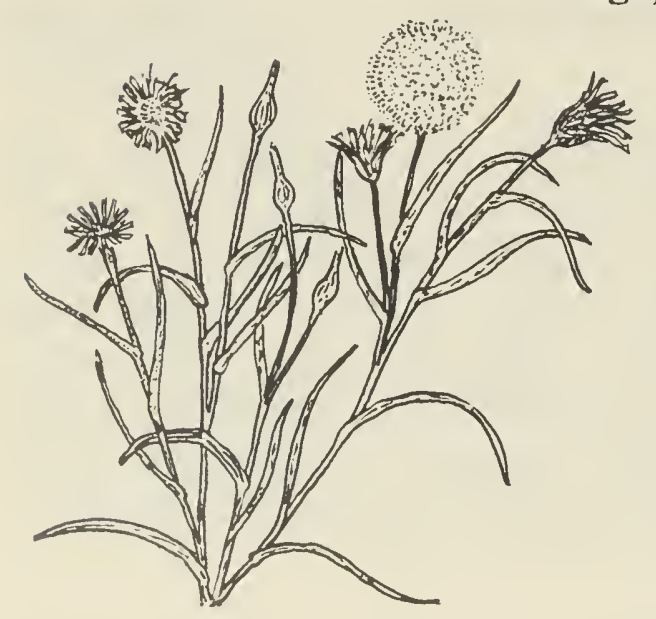

A coarse biennial 6 to 24 inches high, from a deep fleshy taproot. Leaves grass-like, erect, narrow, 4 to 12 inches long, stalkless, clasping at base. Flowers sulphur yellow, $1 \frac{1}{4}$ to 2 inches across, with 10 to 14 green bracts that are longer than florets. Heads single on long stem, which is swollen just below head. Heads very evident in seed, usually 3 to 4 inches in diameter. Seeds tapered to a long beak, ribbed, bearing a parachute of white hairs. Introduced, plentiful on roadsides and in waste places.

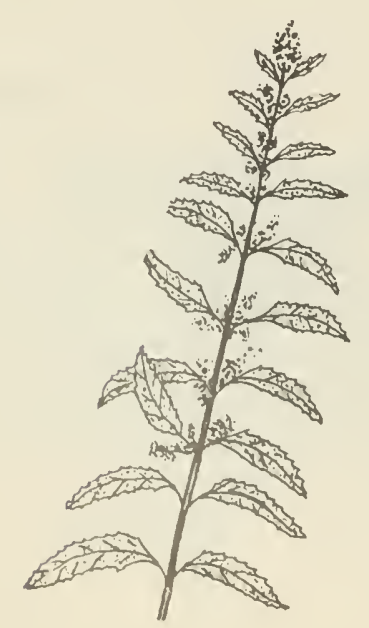

Urtica gracilis Ait.

COMMON NETTLE

A perennial with very coarse rootstocks, which have pink offshoots. Stems erect, usually square in cross section, with ovate to lanceolate, toothed, opposite leaves that bear stinging hairs. Flowers greenish, in clusters in leaf axils. Common around sloughs, bushes, and moist places throughout prairies. 


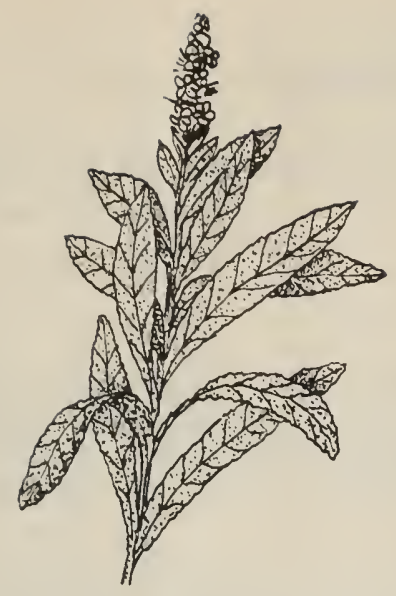

Verbascum thapsus L.

A tall, erect, woolly biennial 1 to 6 feet high. Leaves spatulate to elliptic, densely woolly, 4 to 12 inches long. Flowers almost regular, yellow, with 5 lobes, $\frac{3}{4}$ to 1 inch across, in dense woolly spike, 4 to 24 inches high, lower flowers opening first. Rare, reported from scattered points across southern portion of area.

Veronica peregrina L.

HAIRY SPEEDWELL var. xalapensis (HBK.) St. John \& Warren

An erect, glandular hairy annual or winter annual 4 to 12 inches high. Leaves opposite, linear to spatulate, $\frac{1}{2}$ to 1 inch long. Flowers white, $\frac{1}{8}$ inch across, single in leaf axils. Not common, on moist, sandy soils and in low spots across area.

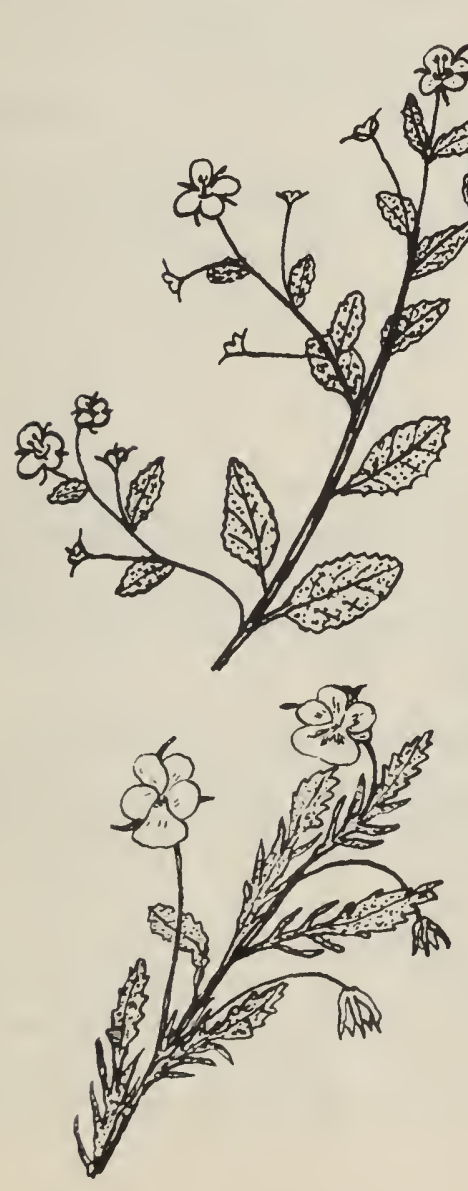

Veronica persica Poir.

BIRD'S-EYE

A low-growing, much-branched, spreading annual that is finely hairy. Leaves short stemmed, oval, $\frac{1}{2}$ to 1 inch long, coarsely toothed. Flowers blue, $\frac{1}{4}$ inch across, single on long stalks from leaf axils. Introduced, becoming a common garden weed in some localities.

Viola arvensis Murr.

WILD PANSY

An irregularly branched annual 4 to 12 inches long, with leafy stems. Lower leaves ovate to round, upper leaves oblong to oblanceolate. Stipules large, toothed, leaf-like. Leaves and center sections of stipules round-toothed at tip. Flowers pale-yellow, upper petals sometimes violet-tipped. Introduced, found in several locations. 


\section{Editor's Note \\ The Spelling of Common Names}

ing rules.

In this book compound common names are written according to the follow-

1. Written as one word.

(a) When the modified word is plant or a type of plant, as in leadplant, skunkbush, peatree, peavine, jewelweed, lungwort; except when the modifier is a hyphened word, as in joe-pye weed, or a proper noun, as in Virginia creeper.

(b) When the modified word is a part of a plant, as in juneberry, twayblade, buffalobur, coneflower, leatherleaf, bladderpod, balsamroot, bugseed, twistedstalk, bluestem, buckthorn, wormwood.

(c) When the modified word is a part of animal anatomy, as in arrowhead, bluelips, cattail, beardtongue; except when the modifier is in the possessive case, as in bird's-eye, crane's-bill.

(d) When the words are figurative or suggestive, as in beggarticks, fairybells, meadowsweet, paintbrush; except when the modifier is in the possessive case, as in baby's-breath, when it is a proper noun or adjectival form of a proper noun, as in Venus-slipper, Indian-pipe, or when letters demand separation for ease in reading or pronunciation, as in morning-glory.

2. Written as separate words.

(a) When the modified word is taxonomically correct, as in red clover (genus Trifolium), alkali grass (family Gramineae), fringed milkwort (genus Polygala), common plantain (genus Plantago).

(b) When the modifier is the word common, false, mock, wild, as in common camass, false flax, mock pennyroyal, wild chives.

(c) When the modifier is a proper noun, as in Douglas hawthorn, Mackenzie's hedysarum.

(d) Exceptions in 1(a).

3. Written hyphened.

(a) When the modified word is not taxonomically correct, as in sweet-clover (genus Melilotus, not genus Trifolium), whitlow-grass (genus Draba, not family Gramineae), sea-milkwort (genus Glaux, not genus Polygala), waterplantain (genus Alisma, not genus Plantago); except in a few instances of spelling of long standing, as burdock, buckwheat.

(b) A compound modifier, as in round-leaved hawthorn, and regardless of whether or not the modified word is taxonomically correct, as in saltmeadow grass (family Gramineae), blue-eyed grass (genus Sisyrinchium, not family Gramineae).

(c) Certain three- or four-word groups, as balm-of-Gilead, butter-and-eggs, grass-of-Parnassus, lily-of-the-valley, touch-me-not.

(d) Exceptions in 1(c), 1(d). 


\section{INDEX TO COMMON AND SCIENTIFIC NAMES}

absinthe, 24

Achillea lanulosa, 21

Agrostemma githago, 21

alfalfa, 49

alyssum, hoary, 27

small, 21

Alyssum alyssoides, 21

amaranth, prostrate, 22

Amaranthus albus, 21

graecizans, 22

retroflexus, 22

Ambrosia artemisiifolia var. elatior, 22 psilostachya var. coronopifolia, 22 trifida, 23

Androsace septentrionalis var. puberulenta, 23

Apocynum androsaemifolium, 23

sibiricum, 23

Arabis glabra, 24

Arctium minus, 24

Artemisia absinthium, 24

biennis, 24

frigida, 25

Asclepias speciosa, 25

aster, rayless See rayless-aster, 27

Astragalus bisulcatus, 25

pectinatus, 25

atriplex, garden, 26

Atriplex hortensis, 26

patula, 26

var. hastata, 26

Axyris amaranthoides, 26

baby's-breath, 41 annual, 40

bassia, five-hook, 26

Bassia hyssopifolia, 26

Berteroa incana, 27

bindweed, field, 33

bird's-eye, 65

bittersweet, 61

bluebur, 44

western, 45

Brachyactis angusta, 27

Brassica juncea, 27

broomweed, common, 40

buckwheat, tartary, 39

wild, 52

bugseed, 34

burdock, lesser, 24

burning-bush, Mexican See summercypress, 44

buttercup, tall, 54

cactus, purple, 48

Camelina microcarpa, 27

campion, bladder, 59

Capsella bursa-pastoris, 28
Cardaria draba, 28 pubescens var. elongata, 28

Carduus nutans, 28

catchfly, forked, 60

night-flowering, 60

sleepy, 59

smooth, 59

cat's-ear, 43

Centaurea diffusa, 29

maculosa, 29

repens, 29

solstitialis, 29

Cerastium arvense, 30

chamomile, scentless, 48 wild, 48

Chenopodium album, 30

rubrum, 30

salinum, 30

chickweed, common, 63

field, 30

chicory, 31

Chrysanthemum leucanthemum, 31

Cichorium intybus, 31

Cicuta douglasii, 31

cinquefoil, rough, 53

rough-fruited, 54

shrubby, 53

Cirsium arvense, 31

flodmanii, 32

undulatum, 32

vulgare, 32

Cleome serrulata, 32

clover, sweet See sweet-clover, 49

cockle, cow, 58

purple, 21

white, 46

Conringia orientalis, 33

Convolvulus arvensis, 33

sepium var. americanus, 33

Coreopsis tinctoria, 33

Corispermum hyssopifolium, 34

Crepis tectorum, 34

cress, Austrian, 55

creeping yellow, 56

globe-podded hoary, 28

heart-podded hoary, 28

marsh yellow, 55

spreading yellow, 56

cryptanthe, Fendler's 34

Cryptantha fendleri, 34

Cynoglossum officinale, 34

cypress, summer See summer-cypress, 44

daisy, oxeye, 31

dandelion, 64

Delphinium bicolor, 35 
Descurainia sophia, 35

Diplotaxis muralis, 35

dock, curled, 57 sand, 57

dogbanc, clasping-leaved, 23 spreading, 23

doorweed, 52

Draba nemorosa, 35

dragonhead, American, 50

Epilobium angustifolium, 36 glandulosum var. adenocaulon, 36

Erigeron canadensis, 36

Erodium cicutarium, 36

Erucastrum gallicum, 37

Erysimum asperum, 37 cheiranthoides, 37

inconspicuum, 37

Euphorbia esula, 38

glyptosperma, 38

helioscopia, 38

serpyllifolia, 38

evening-primrose, white, 51 yellow, 51

Fagopyrum tataricum, 39

false flax, small-seeded, 27

fireweed, 36

flax, toad See toad-flax, 46

fleabane, Canada, 36

flixweed, 35

Galeopsis tetrahit, 39

galinsoga, 39

Galinsoga ciliata, 39

Glecoma hederacea, 39

Glycyrrhiza lepidota, 40

goat's-beard, yellow, 64

goosefoot, red, 30

saline, 30

spear-leaved, 50

grass, whitlow See whitlow-giass, 35

greasewood, 58

Grindelia perennis, 40

ground-ivy, 39

groundsel, common, 59

gumweed, 40

Gutierrezia diversifolia, 40

Gypsophila elegans, 40 paniculata, 41

Haplopappus spinulosus, 41

hawk's-beard, narrow-leaved, 34

hawkweed, orange, 42

Helenium autumnale var. montanum, 41

Helianthus Ienticularis, 41

petiolaris, 42

subtuberosus, 42

heliotrope, spatulate-leaved, 42

Heliotropium curassavicum var. obovatum, 42

hemlock, western water, 31

hemp-nettle, 39 henbane, black, 43

Hieracium aurantiacum, 42

hound's-tonguc, 34

Hyoscyamus niger, 43

Hypochoeris radicata, 43

ironplant, spiny, 41

Iva axillaris, 43

xanthifolia, 43

ivy, ground See ground-ivy, 39

poison See poison-ivy, 55

knapweed, diffuse, 29

Russian, 29

spotted, 29

Kochia scoparia, 44

Lactuca pulchella, 44

scariola, 44

lamb's-quarters, 30

Lappula echinata, 44 redowskii var. occidentalis, 45

larkspur, low, 35

Lepidium densiflorum, 45 perfoliatum, 45

ramosissimum, 45

lettuce, blue, 44 lobed prickly, 44

licorice, wild, 40

Linaria dalmatica, 46 vulgaris, 46

locoweed, early yellow, 51

lupine, silvery, 46

Lupinus argenteus, 46

Lychnis alba, 46

Lygodesmia juncea, 47

Madia glomerata, 47

mallow, round-leaved, 47 scarlet, 47

Malva rotundifolia, 47

Malvastrum coccineum, 47

Mamillaria vivipara, 48

Matricaria chamomilla, 48 maritima var. agrestis, 48 matricarioides, 48

Medicago lupulina, 49 sativa, 49

medick, black, 49

Melilotus alba, 49 officinalis, 49

Mexican burning-bush See summer-cypress, 44

mignonette, yellow cut-leaved, 54

milk-vetch, narrow-leaved, 25 two-grooved, 25

milkweed, showy, 25

Mirabilis hirsuta, 49 nyctaginea, 50

Moldavica parviflora, 50

Monolepis nuttalliana, 50

morning-glory, wild, 33

mullein, common, 65 
mustard, ball, 50

dog, 37

hare's-ear, 42

Indian, 27

tall hedge, 61

tower, 24

tumbling, 60

wild, 60

wormseed, 37

Neslia paniculata, 50

nettle, common, 64

hemp See hemp-nettle, 39

nightshade, black, 61

Oenothera biennis, 51

var. canescens, 51

var. hirsutissima, 51

nuttallii, 51

Opuntia fragilis, 51

polyacantha, 51

orache, 26

Oxybaphus pilosus, 49

Oxytropis macounii, 51

pansy, wild 65

parsnip, water, 61

pepper-grass, branched, 45

common, 45

perfoliate, 45

picradeniopsis, 52

Picradeniopsis oppositifolia, 52

pigweed, red-root, 22

Russian, 26

pineappleweed, 48

Plantago major, 52

var. asiatica, 52

plantain, common, 52

poison-ivy, 55

Polygonum aviculare, 52

convolvulus, 52

Portulaca oleraceae, 53

Potentilla anserina, 53

forma sericea, 53

fruticosa, 53

norvegica, 53

recta, 54

povertyweed, 43

prairie-rocket, small-flowered, 37

prickly-pear, 51

brittle, 51

primrose, evening See evening-primrose, 51

purslane, 53

pygmyflower, 23

radish, wild, 54

ragweed, common, 22

false, 43

great, 23

perennial, 22

ragwort, marsh, 58 tansy, 58

Ranunculus acris, 54

Raphanus raphanistrum, 54

rayless-aster, 27

Reseda lutea, 54

Rhinanthus crista-galli, 55

Rhus radicans var. rydbergii, 55

rocket, sand See sand-rocket, 35

Rorippa austriaca, 55

islandica, 55

sinuata, 56

sylvestris, 56

Rosa woodsii, 56

rose, Wood's, 56

Rumex acetosella, 56

crispus, 57

venosus, 57

Russian-thistle, 57

sage, pasture, 25 wood, 57

Salsola pestifer, 57

Salvia sylvestris, 57

sand-rocket, 35

Saponaria vaccaria, 58

Sarcobatus vermiculatus, 58

Senecio jacobaea, 58

palustris, 58

vulgaris, 59

shepherd's-purse, 28

Silene antirrhina, 59

cserei, 59

cucubalus, 59

dichotoma, 60

noctiflora, 60

silverweed, 53

Sinapis arvensis, 60

Sisymbrium altissimum, 60

loeselii, 61

Sium suave, 61

skeletonweed, 47

sneezeweed, mountain, 41

snowberry, western, 63

Solanum dulcamara, 61

interius, 61

nigrum, 61

triflorum, 62

Sonchus arvensis, 62

asper, 62

oleraceus, 62

sorrel, sheep, 56

sow-thistle, annual, 62

perennial, 62

prickly, 62

speedwell, hairy, 65

Spergula arvensis, 63

spiderflower, 32

spurge, leafy, 38

ridge-seeded, 38

sun, 38

thyme-leaved, 38 
spurry, corn, 63

star-thistle, yellow, 29

Stellaria media, 63

stinkweed, 64

stork's-bill, 36

summer-cypress, 44

sunflower, prairie, 42

showy, 41

tuberous-rooted, 42

sweet-clover, white, 49

yellow, 49

Symphoricarpos occidentalis, 63

Tanacetum vulgare, 63

tansy, 63

Taraxacum officinale, 64

tarweed, 47

thistle, See also Russian-thistle, 57; yellow star-thistle, 29

bull, 32

Canada, 31

Flodman's 32

nodding, 28

wavy-leaved, 32

Thlaspi arvense, 64 tickseed, common, 33

toad-flax, broad-leaved, 46 yellow, 46

tomato, wild, 62

Tragopogon dubius, 64

tumbleweed, 21

umbrèllawort, hairy, 49

heart-leaved, 50

Urtica gracilis, 64

Verbascum thapsus, 65

Veronica peregrina var. xalapensis, 65 persica, 65

vetch, milk See milk-vetch, 25

Viola arvensis, 65

wallflower, western, 37

water hemlock, western, 31

whitlow-grass, wood, 35

willowherb, northern, 36

wormwood, biennial, 24

yarrow, woolly, 21

yellowrattle, 55 
The text type is Times roman and bold and the headings are Caslon bold. The book was printed by the QueEN's Printer, Ottawa, Ontario. 




